\title{
Liberty, property and the state: the ideology of the institution of national English town and country planning
}

Article

Accepted Version

Creative Commons: Attribution-Noncommercial-No Derivative Works 4.0

Shepherd, E. (2020) Liberty, property and the state: the ideology of the institution of national English town and country planning. Progress in Planning, 135. 100425. ISSN 0305-9006 doi: https://doi.org/10.1016/j.progress.2018.09.001 Available at https://centaur.reading.ac.uk/78937/

It is advisable to refer to the publisher's version if you intend to cite from the work. See Guidance on citing.

To link to this article DOI: http://dx.doi.org/10.1016/j.progress.2018.09.001

Publisher: Elsevier

All outputs in CentAUR are protected by Intellectual Property Rights law, including copyright law. Copyright and IPR is retained by the creators or other copyright holders. Terms and conditions for use of this material are defined in the End User Agreement.

www.reading.ac.uk/centaur

\section{CentAUR}


Central Archive at the University of Reading

Reading's research outputs online 


\title{
Liberty, Property and the State
}

\section{The Ideology of the Institution of National English Town and Country Planning}

\author{
Edward Shepherd \\ edward.shepherd@ reading.ac.uk
}

Accepted for publication in Progress in Planning.

\begin{abstract}
The research explores the relationship between national political ideologies and policy and legislative changes in national English town and country planning. English national planning policy making is theorised as being partly driven by ideological contestation. The research contributes to the understanding of the nature of the policies this process produces, and how it is that the English planning system has become a 'wicked problem' for national policy makers.
\end{abstract}

The analysis focuses on two periods: the ' 1947 system' period and the early post-2010 Conservative-led Coalition government period. The '1947 system' period has been selected as it is a key phase in the institutionalisation of English town and country planning into a formal institution of the state. The early Coalition government period has been chosen for analysis as it is the most recent period of significant institutional change. Both of these periods are contextualised through a discussion of developments in politics and planning in the preceding decades.

The research shows that the institution of national English town and country planning is intimately connected with concepts which are deeply prone to ideological contestation (such as liberty, property and the state), and that these competing contestations influence competing visions for the form and structure of the institution. This ideological quality of 'thinking about planning' means that its institutionalised form is inherently prone to change.

The research proposes a theory for the analysis of ideology and ideas as they relate to institutional change, and offers an account of the power of ideology to define the limits of politically acceptable thought, and 
thus shape policy and legislative programmes for English planning. The contribution of this research is towards an understanding of why ideologies have shaped the institution of national English town and country planning over time.

Keywords: ideology; institutional change; Michael Freeden; planning; political ideologies 
"Practical men, who believe themselves to be quite exempt from any intellectual influences, are usually slaves of some defunct economist. Madmen in authority, who hear voices in the air, are distilling their frenzy from some academic scribbler of a few years back.” (Keynes, 1936: 383).

\section{Introduction}

The election of the Conservative-led Coalition government in May 2010 precipitated major changes to the policy and legislative framework of English town and country planning. The new government moved swiftly to dismantle significant parts of the system which had been put in place by the previous Labour Party government. This included the removal of statutory regional planning and the replacement of over 1,000 pages of national planning policy guidance with a single National Planning Policy Framework (DCLG, 2012b) (“NPPF”) of just under 60 pages. ${ }^{1}$

This was accompanied by the insertion of a new tier of statutory plan-making at the neighbourhood level and significant liberalisation of the 'permitted development' rules, thereby allowing a wider range of development to take place without the need to apply for planning permission. All of these changes were introduced within the first three years of the Coalition government, and were accompanied by a political agenda which simultaneously sought to promote the decentralisation of the planning system as part of a strategy to free society from "an over-centralised state that saps responsibility and initiative from people" (Conservative Party, 2009a: 2), while at the same time seeking to deregulate and restructure the system to make it more supportive of development and economic growth (Conservative Party, 2009b).

The Coalition government's planning reforms were described as being simply 'common sense' by thenConservative Secretary of State for Communities and Local Government Eric Pickles (DCLG, 2012a). Yet despite having been clearly foregrounded in the Conservative Party's policy papers published in the months leading up to the 2010 election, the swiftness with which some of them were introduced and their seeming lack of regard for an evidence-based approach to policy making surprised some.

For example, when Eric Pickles announced the abolition of the regional tier of planning, 29 signatories reflecting a diverse range of interests wrote to the government warning about the possible negative effects of their removal (RTPI, 2010). The House of Commons Communities and Local Government Committee in its report on the removal of regional planning also expressed scepticism regarding this change, and

\footnotetext{
${ }^{1}$ However, it should be noted that since the NPPF was published in 2012, a lengthy and continuously-updated National Planning Practice Guidance website has been put online by the government, containing much additional guidance expanding on the NPPF.
} 
recommended that the "Government adopt a more evidence-based and consultative approach to policy making in the future" (House of Commons, 2011a: 11).

The government's initially adversarial approach to introducing the NPPF (Osborne \& Pickles, 2011; Kirkup, 2011; Sparrow, 2011) contributed to it being mired in a bitter public controversy between the government, the countryside protection lobby and the development industry, which was focused around the degree to which the NPPF was being used to recalibrate the planning system to make it more supportive of economic growth at the expense of the environmental and social elements of the sustainable development agenda.

Given the nature of the Coalition's reforms, their swiftness, and the legitimising arguments from central government which accompanied them, it was apparent that practitioners embedded within the institution of English planning were having their professional practice shaped by the political thinking of those in central government. It seemed that practitioners in England in the post-2010 political environment were being made subject to the intellectual influences of 'scribblers' (defunct or otherwise) through the power of their ideas over the professed 'practical men' and women in central government. Of course, this was by no means a new feature of English planning. Institutional change has been an almost constant feature of English planning, particularly over the last thirty years, so that "planning reform is now with us on a near permanent basis" (Allmendinger and Haughton, 2015: 29).

The aim of this paper is to analyse how the institution of English planning at the national level has been shaped by the political ideologies of those in positions of power in central government over time, so that the ideological dimension of the significant planning reforms introduced after 2010 may be seen in historical context. Furthermore, by analysing the relationship between national political ideologies and institutional change at the national level, we may better understand why the institution of national English planning has been prone to change, how it has simultaneously endured, and how it is that the English planning system has itself become such a 'wicked problem' (Rittel \& Webber, 1973) for national policy makers.

To achieve this, the paper will adapt Michael Freeden's (1996, 1998, 2001, 2013a, 2013b) morphological approach for the analysis of political ideologies so as to analyse institutional change and stability in the context of national English planning. Freeden's approach frames political ideologies as comprising shifting morphologies of essentially contested concepts (such as liberty, property and the state) whose role is to seek to fix the terms by which political reality is understood. The morphological approach is therefore capable 
of being used to systematically analyse ideologies through deconstructing their component concepts and the relations between them. However, Freeden's approach has been developed to be applied to 'abstract' political ideologies such as 'conservatism' and 'liberalism' - it therefore needs to be adapted to help us think about how ideology finds institutional expression in national English town and country planning.

By incorporating insights from the 'ideational turn' in political science and discursive or constructivist institutionalism (Béland \& Cox, 2011a; Blyth, 2002; Schmidt, 2010), this paper theorises planning as comprising ideas and concepts which have discursively interacted with the policy making process and been adopted as part of the institutional framework. Institutions can here be defined as "sets of regularized practices with a rule-like quality" such as "regulations backed by the force of law or organizational procedure" (Hall \& Thelen, 2008: 9). Shifts in the meanings of concepts important to planning in the ideologies of those in political power can therefore be expected to be expressed in some way through shifts in the institutional framework for planning which is partly shaped by those concepts and the relations between them (Shepherd, 2017).

More empirically, the paper will contribute to the understanding of the relationship between political ideologies and the institution of English town and country planning over its history, with an emphasis on the role of these ideologies in policy reform under the post-2010 Coalition government. Crucially, the paper does not therefore propose a theory and analysis which claims to explain the phenomenon of English planning reform or institutional change overall, but rather it proposes a theory and analysis of the relationship between political ideologies and change in the institution of planning within central government. This will allow for conclusions to be drawn regarding the ideological dimensions of the problem of the change and paradoxical stability of the institution of national English town and country planning over time.

The paper comprises eight sections. Following this introduction, the second section discusses the history of the concept of ideology and introduces Freeden's morphological approach for the analysis of political ideologies and how this may be adapted to help us to understand shifts in the institution of national English town and country planning. In order to execute a morphological analysis of the role of ideology in institutional change, it is necessary to identify those contested concepts which have structured the ideology of the institution of planning in the past and which are still active today. The third section therefore gives an account of the ideational context in which the modern institution of English planning arose and how ideological concepts found concrete expression in the planning system as enacted through the reports and Acts of Parliament of the 1930s and 1940s. It is this latter process which is analysed in section four, which 
shows how ideological debates around the proper meanings of and relations between concepts such as liberty, property, the state, society, town and country were at the core of the emerging institution of English town and country planning.

The fifth section gives an account of the neoliberalisation of British political life after the 1970s and how this shifted the ideological terrain both at the national political level and for the institution of planning, thereby altering the terms by which concepts of central importance to planning were understood. The sixth section offers an analysis of the conceptual amalgam of the ideology of the conservatism of the Parliamentary Conservative Party in the years leading up to the 2010 general election. It shows how ideologues in and around the Conservative Party at the time sought to address the challenge to traditional conservative conceptions of society and the state posed by a neoliberal conception of liberty by evoking the concept of community, with significant implications for the institution of town and country planning. The seventh section discusses the various planning reforms which were then introduced by the Conservativeled Coalition in the first few years of government, and unpicks the latent tensions and logical contradictions inherent in them, and traces them back to those qualities which are also present in the overarching ideological framework. Finally, the paper ends with a conclusion which reflects on the role of ideology in institutional change and stability, as well as on the lacunae and limitations of the form of analysis presented here.

The overarching objective of this paper is to present a theory for the study of the relationship between shifts in the political ideologies of national governments, and shifts in the institutional frameworks for town and country planning at the national level over time. The paper presents just one way in which this theory could be operationalised through the analysis of some key periods of institutional change in English planning history, but there could be many ways of conducting the analysis. The one presented in this paper is intended to be defensible and coherent, but it is not claiming exclusivity. This paper is therefore presented in the spirit of open debate and it is hoped that others may apply the theory to other contexts (such as more 'local' levels of institutional change in planning which perhaps challenge or subvert those agendas set at the national level), or critique and improve upon the reading of English planning history presented here. The concept of ideology has much to offer analyses of planning; this paper seeks to demonstrate this by bringing it to the fore. 


\section{Ideology, Theory and Method}

\subsection{The Concept of Ideology: A Brief History}

The contributions of some important figures in the history of ideology will now be briefly outlined in order to identify the key features of the concept, and to foreground the discussion of the important contribution made by political theorist Michael Freeden. It will be shown how the concept of ideology offers ways in which to conceptualise problems of political meaning and power. We shall see that this partly derives from the historical evolution of the concept of ideology, which follows a trajectory from the Enlightenment project, through German idealism, onto Marxism, structuralism and all the way up to and beyond poststructuralist and post-Marxist thought.

\subsubsection{Enlightenment Origins}

The word 'ideology' was coined in 1796 by French aristocrat and philosopher Antoine Destutt de Tracy (1754 - 1836). As set out in his Les Elements de I'Ideologie (1801), for him 'ideology' meant the 'rational study of ideas', a "science of thought” i.e. 'idea-ology' (MacKenzie, 1994: 3). Through this study, he hoped to reveal the nature of ideas, their origin in man's experience of the world (rather than as having any idealist metaphysical source), and through this to reject false notions which obstruct mankind's development.

We see here a positive conception of ideology as a methodical study of ideas, as part of the Enlightenment project to strip away illusions and reveal the world as it truly is. We see here also the beginnings of radicalism in the story of ideology, for this emphasis on the study of thought and the rejection of false ideas came to be associated with political liberalism and republicanism and, therefore, the rejection of traditional state power based on theological legitimation and a cult of personality in the form of monarch or emperor. In France, this eventually brought de Tracy and others into conflict with Napoleon, who labelled them 'ideologues' (MacKenzie, 1994: 4; see also Larrain, 1979: 28).

We also see here a more explicitly philosophical current in the concept of ideology, one which asks questions about the relationship between ideas and the material world and, therefore, knowledge. Indeed, de Tracy was reacting in part to these relationships as conceived in philosophical idealism, a key figure in which was G.W.F. Hegel (1770 - 1831) who was in turn responding to the philosophy of Immanuel Kant (1724 - 1804). It is Hegel, and his followers the 'Young Hegelians', who would influence Karl Marx (1818 - 1883) and Friedrich Engels (1820 - 1895), while simultaneously providing them with an intellectual tradition to rebel against. 


\subsubsection{Ideology, Idealism and Science}

While Marx and Engels were strongly influenced by Hegel's dialectical method and his analysis of history as development, they objected to the idealists' emphasis on the ideal over the material. They were in opposition to the idea of an abstract consciousness determining mankind's historical development, and instead sought to turn the argument 'on its head': "In direct contrast to German philosophy which descends from heaven to earth, here we ascend from earth to heaven...Life is not determined by consciousness, but consciousness by life" (Engels \& Marx, [1846] 1970: 47). For them, history was therefore not determined by the development of consciousness, but rather consciousness determined by the historical development of social and material relations. Consciousness is not, therefore, independent of material reality: it is a 'social product'.

For Marx, therefore, through the real contradictions of capitalism (e.g. distorted social and material relations brought about by restricted productive forces and the division of labour) the consciousness of human subjects also becomes distorted as it seeks to resolve these contradictions which are not overcome in practice (Larrain, 1979: 46). These distortions in consciousness conceal the true nature of the distortions of social and material relations within the capitalist system, thus legitimising them and helping to reproduce a system of class domination. By characterising such distortions as ideology, the early Marx and Engels thus gave the concept of ideology a pejorative edge. ${ }^{2}$ They also framed ideology in contrast to science which they thought could help dispel ideology by revealing its true nature, therefore prompting revolutionary practice/praxis to change material structures and, therefore, consciousness.

\subsubsection{Ideology as World-view}

Thinkers after Marx started to diffuse the specificity of the concept of ideology by variously broadening its class dimension and/or relaxing its preoccupation with the relationship between consciousness and the material world, and distortion, falsity and truth. This resulted in an extension of the concept to cover proletarian as well as bourgeois ideology (Vladimir Lenin [1870 - 1924] - see Lenin, [1902] 1961), as well as the subsuming of the concept of ideology in to a broader concept of the 'style of thinking' or world-view (or 'Weltanschauung') of a group based on its social position, in the context of the "disappearance of a unitary intellectual world with fixed values and norms" (Mannheim, [1936] 1954: 37). For Karl Mannheim (1893 - 1947) writing in the 1920s: "It is no longer the exclusive privilege of socialist thinkers to trace

\footnotetext{
2 This account draws on the early Marx and Engels' analysis of ideology, which was not consistently applied in later works. For a discussion, see Eagleton (2007: 70 - 91).
} 
bourgeois thought to ideological foundations and thereby to discredit it. Nowadays groups of every standpoint use this weapon against all the rest" (Mannheim, [1929] 1954: 67).

The concept of ideology thus came to be associated with a system of ideas associated with the interests of a particular class or group, bourgeois or otherwise. We see in this the development of a more sociological conception which Purvis \& Hunt (1993) define as a "plural conception of ideology as the outcome or result of the specific social position of classes, groups or agents" and which "simply describes the framework of meanings and values within which people exist and conduct their social lives" (1993: 478 - 479).

\subsubsection{Culture and Hegemony}

Antonio Gramsci's (1891 - 1937) treatment of the concept of ideology also extended it beyond a purely negative conception. Through his development of the concept of 'hegemony' (Gramsci, 1971), Gramsci expanded upon a view of ideology as a "relatively formal and articulated system of meanings, values and beliefs, of a kind that can be expanded to a "worldview' of a "class outlook", to draw attention to "the whole lived social process as practically organized by specific and dominant meanings and values" (Williams, 1977: 109). Through control of the institutions of economic, political, social and cultural life, the worldview of the dominant class becomes the "common sense' of a whole social order" (Eagleton, 2007: 114) and secures its ideological dominance. Those thus dominated therefore consensually share the worldview of the dominators. However, importantly Gramsci also allowed space for the potential of a counter-hegemony to creatively challenge dominant ideas and adjust existing power structures, thereby approaching the more 'sociological' conception of ideology.

By virtue of its emphasis on lived experience (rather than structures of abstract and imposed ideas), Gramsci's concept of hegemony is close to that of 'culture'. Indeed, Gramsci was a significant influence on the discipline of Cultural Studies which emerged in the 1950s and 1960s. For Raymond Williams (1921 - 1988) hegemony was "in the strongest sense a 'culture', but a culture which has also to be seen as the lived dominance and subordination of particular classes" (Williams, 1977: 110). Williams and other cultural theorists such as his friend Stuart Hall (1932 - 2014) therefore engaged in a project to try to bring to light the ideological assumptions underpinning the humanist tradition by conducting "an ideological critique of the way humanities and the arts presented themselves as parts of disinterested knowledge" (Hall, 1990: 15). They therefore conducted analyses of cultural artifacts (such as works of literature and mass media) informed by Marxist theory in an attempt to demystify their ideological provenance and disrupt the hegemony some of them helped secure (e.g. Williams, 1960). 
Gramsci was also an important influence on Louis Althusser (1918 - 1990) and his highly influential yet austere, anti-humanist and structuralist take on ideology, in which Ideological State Apparatuses work an insidious hegemonic influence on subjects who are subjected (or 'interpellated') by ideology and can never escape it. For Althusser, following Marx, ideology "represents the imaginary relationship of individuals to their real conditions of existence" (Althusser, [1971] 1984: 36) and helps secure their domination. In Althusser's conception, “individuals are always-already interpellated by ideology as subjects, which necessarily leads us to one last proposition: individuals are always-already subjects" (Althusser, [1971] 1984: 50 - emphasis in original). For Althusser, the structure of ideology, like Freud's conception of the unconscious, has always been "present in the same form throughout what we call history" (Althusser, [1971] 1984: 35). However, Althusser makes an important distinction between a theory of ideology in general, and a theory of particular ideologies which "always express class positions" (Althusser, [1971] 1984: 33 - emphasis in original). It is ideology in general which is eternal and has 'always already' subjected individuals; particular ideologies are the specific historical forms by which this is achieved and it is through these structures that the domination of one class over others is secured.

\subsubsection{The Structure of Language}

The austerity of Althusser's theory of ideology in general as an eternal structure of lived relations has its roots partly in the structural linguistics of Ferdinand de Saussure (1857 - 1913). He sought to establish linguistics as a science by emphasising its structural dimension. It is from him that we get the now-familiar concepts of sign, signifier and signified which are of such importance in post-structuralist thought. Saussure also introduced the distinction between language (langue) and speech (parole) which he used to argue that language was a structural system that shaped speech (Saussure, 1983). The crucial implication of this was to reveal that language was "an autonomous object which has a stability independent of the actual use that individuals may make of it" (Larrain, 1979: 131).

Saussure's semiotics therefore introduced the possibility that speech in some way obscures its underlying structure. He also splintered words and ideas into their structural components and functions of sign, signifier and signified, and by demonstrating the seemingly arbitrary connection between signifier and signified hinted at the potential arbitrariness of meaning. Linked to this is the morphological dimension of the meaning of signs. That is to say, the meaning of a word is partly a function of its positioning and relations with other words. In the structure of a sentence, this is obvious: the word 'liberal' means different things in the statements 'she is a liberal' and 'you should use liberal amounts of seasoning'. We therefore interpret words from their relational context. 
But Saussure's ideas also have further implications for language as being potentially capable of conveying multiple (and potentially unconscious and therefore unintended) meanings. It is partly as a result of this that Paul Ricœur (1913 - 2005) spoke of ideology as having a 'surplus of meaning' by which he meant that ideologies potentially convey more information than their ideologues are aware of or could intend (Freeden, 2003: 46-47). Larrain (1979: 133) argues that this is due to the two levels of meaning in speech (manifest) and language (latent), with the latent content representing the underlying ideological structure of a discourse of which the communicator is not fully aware.

\subsubsection{Post-structuralism and the Indeterminacy of Meaning}

It is these themes which were developed in greater detail by post-structuralist thinkers such as Roland Barthes (1915 - 1980) and Jacques Derrida (1930 - 2004). In different but related ways they pushed the destabilising implications within semiotics so as to question the possibility of any control over meaning. This led to Barthes' famous notion of the 'death of the author'. This is the idea that that author is not the arbiter of the 'ultimate meaning' of a text, that "a text is not a line of words releasing a single 'theological' meaning (the 'message' of the Author-God) but a multi-dimensional space in which the variety of writings, none of them original, blend and clash" (Barthes, 1977: 146). Interpretive power lies with the reader and thus becomes a matter of the overthrow of the author. Interpretation is, therefore, a radical act (Barthes, 1977: 146 - 147).

A text's meaning is therefore rendered fluid and dynamic. What is more, Barthes theorised that meaning operates on at least two levels - the surface, primary 'denotation' of ordinary language, and the secondary 'connotation', a kind of mythical language in which multiple connotations resonate. An important part of the production of meaning was to interpret and reveal this secondary level of almost hidden, or ideological, meaning (see Barthes, 1972).

Derrida also sought to uncover obfuscated levels of meaning within language through its deconstruction. For him, any text conveys unintended meanings. Text, language and meaning work through a great web, a matrix of other texts and meanings which is beyond the control of the author (Harvey, 1989: 50-51). Deconstruction therefore involves looking for resonances and connotations within texts which point to other texts. Meaning could therefore be said to be relational not just in terms of between words, but also in terms of relations between texts, and between readers and texts.

Of course, the post-structuralist emphasis on the indeterminacy of meaning has potentially nihilistic implications. Followed through to its logical conclusion, it suggests that meanings are so numerous so as 
to make the very notion of 'meaning' meaningless. This has serious implications for the concept of ideology as it potentially atomises the group into its component parts. Ideology then loses its shared class, or group interest dimension. It also starts to seem very difficult, if not impossible, to interpret or study ideology or 'particular ideologies' at all. How can there be a shared system of meaning such as that supposedly presented by ideology, when meaning cannot be systematic, and cannot truly be shared?

However, there is a less nihilistic way of conceiving the impact of post-structuralism on ideology. The emphasis on pluralism and variance in meaning can be interpreted as suggesting that ideologies can be regarded as "devices specifically capable of coping with the indeterminacy of the political messages" circulating in society, and that this indeterminacy is handled by "selecting, privileging, and prioritising certain social meanings among all those available" (Freeden, 2003: 50). This selection can be understood in terms of 'discourse', which can be defined as "the individual social networks of communication through the medium of language or non-verbal sign-systems" (Purvis \& Hunt, 1993: 485), the analysis of which "attends to the play of social power within language itself" (Eagleton, 2007: 195).

\subsubsection{Ideology and Discourse}

The precise relationship between ideology and discourse is often confused and the two terms are sometimes used synonymously (Holborow, 2007: 52). It is not within the scope of this paper to offer an analysis of the similarities and differences between 'discourse' and 'ideology' - the terms of any such analysis would obviously depend on how one defines the two concepts, and from which theoretical tradition (or discourse) the analysis is speaking. ${ }^{3}$ However, the concept of discourse might be said to be employed to overcome the difficulties arising from an abstract and systematic conception of ideology, as it brings the analytical focus to what is said, how it is said, in what context and to what effect. The concept of discourse therefore focuses on material practice rather than abstract forms and, for the purposes of this paper, it may be considered as being how ideologies find agency in the world (although not all discourses are ideological).

The analysis of discourse therefore offers a way to investigate and decode cultural messages which are part of the naturalisation of ideas which could be thought of as ideological (e.g. about race, gender, class, or what agendas are to be prioritised in a planning system). As Freeden (2003: 104) argues, this connects ideology (and discourse) with themes of identity. How do individuals and groups in society perceive or represent themselves? How are they represented in society?

\footnotetext{
${ }^{3}$ For a thought-provoking discussion on this, see Purvis \& Hunt (1993).
} 
Another important aspect of discourse analysis is that it can be oriented towards critiquing and revealing the hidden dimension of discourse and the distortions in meaning that arise (see Fairclough, 2010). This has a clear resemblance to the Marxian conception of ideology in the pejorative sense. However, discourse analysis can also allow for the implications of postmodern pluralism, and the existence of multiple ideologies which are neither necessarily true nor false but which can reveal much about how society and the groups within it are reproduced.

Michel Foucault (1926 - 1984) in particular was concerned with what the careful study of discourses could reveal about the role of power in the construction of knowledge through the "types of discourse which...[society] accepts and makes function as true" (Foucault, [1977] 1980b: 131). As an historian, Foucault also brought a particular approach to the analysis of discourses in historical contexts. His earlier 'archaeological' (e.g. [1966] 2002) and later 'genealogical' (e.g. [1975] 1977) approaches revealed historical discursive discontinuities and breaks and therefore acted as a corrective to the Hegelian and Marxian (and, indeed, Liberal) conception of history as a developmental process.

Through his Nietzschean genealogical method in particular, Foucault was concerned with paying attention to "local, discontinuous, disqualified, illegitimate knowledges against the claims of a unitary body of theory which would filter, hierarchise and order them in the name of some true knowledge and some arbitrary idea of what constitutes a science and its objects" (Foucault, [1977] 1980a: 83), thereby revealing the contingent discursive conditions which could give rise to a knowledge of 'truth' within a particular period. Essentially, this was a project concerned with uncovering the underlying fragmentary conditions for the imposition of the dominant and unitary discourses which constitute our often arbitrary knowledge.

The implications of post-structuralist thought on language and meaning as well as the preoccupation with discourse have been taken up and developed by a group of thinkers who have been labelled 'post-Marxists', with 'post-Marxism' defined as 'the process of reappropriation of an intellectual tradition [Marxism], as well as the process of going beyond it" (Laclau and Mouffe, [1985] 2001: ix). Key figures are Ernesto Laclau (1935 - 2014), Chantal Mouffe (1943 - ) and Slavoj Žižek (1949 - ). In different ways, their theories are concerned with society, its 'plurality of subjects' and how individual subjects (re)produce themselves in society through discourse. For Laclau and Mouffe ([1985] 2001: 193), for example, the social cannot be reduced to any single 'essence', and any attempt to do so through imposing a 'system of equivalences' necessarily suppresses the political, because for them it is social difference, division and antagonism which make up the contingent and ambiguous nature of the social which any truly democratic system should take in to account. 
For Žižek, in crude terms, ideology 'makes' the world, sutures together its shifting fragments into an illusory coherence (or 'system of equivalences'), transitory structures which may be incommensurable with each other and may act to conceal the political. Therefore, the "fundamental level of ideology...is not that of an illusion masking the real state of things but that of an (unconscious) fantasy structuring our social reality itself” (Žižek, [1989] 2008: 30). This represents a break with the Marxian conception of ideology which stresses the relational connection between consciousness and material reality, and the economic base. By collapsing the "world into word" (Zhao, 1993: 80), the post-Marxists have in some sense inverted Marx's own 'inversion' of Hegelian idealism: all 'knowledge' is ideological. For Žižek, this risks rendering 'ideology critique' self-defeating:

"Does not the critique of ideology involve a privileged place, somehow exempted from the turmoils [sic] of social life, which enables some subject-agent to perceive the very hidden mechanism that regulates social visibility and non-visibility? Is not the claim that we can accede to this place the most obvious case of ideology? Consequently, with reference to today's state of epistemological reflection, is not the notion of ideology self-defeating?"

(Žižek 1999, as quoted in Cloud \& Gunn, 2011: 408)

Post-Marxists can therefore be argued as having undermined the "theoretical foundations and epistemological categories that have made Marxian conceptions of ideology meaningful" (Zhao, 1993: 71). However, there remains much of analytical use in the concept as the remainder of the paper seeks to demonstrate.

\subsection{A Theory of Ideology: The Morphological Approach}

The objective of this paper is to contribute to the understanding of the relationship between political ideologies held by those in positions of power in and around central government, and the institution of national English town and country planning. The previous review of some of the various ways in which the concept of ideology has been used in the development of 20th century thought suggests that ideology has a structural function in terms of its role in articulating and legitimising the political interests of groups, but that it also comes with a post-structural semantic unreliability which threatens to undermine its structural dimension to reveal the inherent instability of political meanings. It is the acceptance of both of these seemingly contradictory qualities of ideology which informs Michael Freeden's 'morphological approach', gives it its analytical power and makes it suitable for the analysis of the problem at hand (Freeden, 1996, 1998, 2001, 2013a, 2013b). 
Michael Freeden is a political theorist who has developed an influential theory of ideology in general and how this manifests in particular ideologies. However, despite his use of the concept of ideology, Freeden is not speaking from a Marxist theoretical tradition (although he is inevitably influenced by it). He does not, therefore, set out his philosophical position regarding the relationship between consciousness and the material world, or history and the development of consciousness. His conception of ideology is not preoccupied with questions of falsity or truth and how knowledge is (re)produced.

Freeden's use of the concept is, therefore, more neutral and linguistic rather than pejorative: he defines ideologies as "systems of political thinking, loose or rigid, deliberate or unintended, through which individuals and groups construct an understanding of the political world they, or those who preoccupy their thoughts, inhabit, and then act on that understanding" (Freeden, 1998: 3). He is therefore concerned with identifying the structural qualities of particular political ideologies, and how these structures shape the terms by which groups interpret (and attempt to control) the political. This could involve distortions and untruths (such as those which may be found in racist ideologies), but Freeden is not concerned with critically exposing such distortions as much as he is concerned with understanding them and how they may shape political 'reality'.

Freeden's central argument is that political ideologies such as liberalism, socialism and conservatism can be theorised as comprising a Suassurian morphology of 'essentially contested concepts'. These are the types of concepts with which political philosophy, aesthetics and the philosophy of history are concerned; they are broad, complex and by their nature inspire "endless disputes about their proper uses on the part of their users" (Gallie, 1956: 169). For Freeden, such concepts could include liberty, rights, equality, justice and democracy (Freeden, 1998: 61). These concepts can be identified as being present in different formations within the morphological assemblages which comprise various political ideologies. Crucially, it is a function of political ideologies to seek to fix and control the meaning of those essentially contested concepts with which they are concerned, an activity Freeden calls 'decontestation' and which he sees as "the essence of the ideological act, or thought-practice" (Freeden, 2006: 19).

A political ideology, then, obtains its identity and sense of coherence as a result of the essentially contested concepts it 'comprises' and how it seeks to control the meanings of and relations between these concepts in the face of contestation from competing ideologies. To use an essentially contested concept "means to use it against other uses and to recognize that one's own use of it has to be maintained against these other uses...to use it both aggressively and defensively" (Gallie, 1956: 172). Ideologues are locked in unending 
conflict over the meaning of essentially contested concepts comprising their ideologies, and this conflict is unending as there can be no 'proof' of an objectively true or correct decontestation of them.

This implies that 'outside' of the internal 'logic' of an individual ideology, decontestation can never be total. An ideology must always justify itself when it comes in to contact with an 'other'. Contestation is therefore a process, with 'successful' decontestation (i.e. total control over meaning) an ever-receding goal. To achieve total hegemonic decontestation of a concept would be to transform its nature from that of being an essentially contested concept. In the world of political practice (the forum in which competing ideologies jostle for control), decontestation is then perhaps a matter of degree. A 'dominant' ideology may have a significant degree of political control over the meaning of the contested concepts with which it is concerned, but it must continually struggle to re-exert this control in the face of competing contestation. Following Gramsci, hegemony is not total and must be continually struggled for.

Freeden identifies three 'levels' of concepts comprising the morphological structure of an ideology: the core, adjacent and peripheral. Core concepts are of most fundamental importance to the integrity of a political ideology. For example, the ideology of liberalism would be unimaginable without the concept of liberty at its core (although precisely what this concept is taken to mean is another matter). Adjacent concepts complement the core concepts to give the ideology richness and nuance, while peripheral concepts are less important to the integrity of the ideology and can include 'perimeter' concepts which are theorised as being "specific ideas or policy-proposals rather than fully fledged concepts" (Freeden, 1998: 78). Perimeter concepts are therefore the means by which the more abstract core concepts find agency in the world. In these terms, a political ideology can be 'mapped' through an analysis of the morphology of the various concepts with which it is concerned.

However, this is not to suggest that political ideologies are theorised as being entirely internally consistent and coherent. Ideology, due to its abstraction is often contradictory and incoherent, although there must remain some degree of coherence for it to be an ideology. In Heywood's (2012: 13) terms, they must only be "more or less coherent". In this sense, ideology can be conceived of as political philosophy's unreliable doppelgänger: it may have the appearance of coherence and rigour, but this may start to dissolve upon closer inspection. This is perhaps due to the role of political ideology as sometimes being to put the abstract ideas of political philosophy in to programmes of political action to produce desired changes in political institutions and society. Something will inevitably be (sometimes grossly) simplified and lost in translation, with internal contradictions in the parent philosophy being made evident through contact with the grubby world of politics. 
Crucially, Freeden's approach acknowledges the dynamic nature of ideologies (and the concepts comprising them), both at any given moment and over time. For Freeden, the conceptual morphology of an ideology may change over time and space, thus changing the ideology. Ideology does not exist purely in the abstract world of thought, but is very much related to historical and geographical context. There is therefore not one liberalism, nor one socialism, but many varieties of liberalisms and socialisms existing across various places across various times. Yet these various manifestations will share certain conceptual features with their 'family relations' and through understanding the similarities and differences in these conceptual formations, the phenomenon of ideological change and stability may be analysed.

By focusing on concepts as units of analysis, the morphological approach moves beyond the simplistic two dimensional 'left-right' axis of political thinking. It achieves this by acknowledging that 'different' ideologies may share some of the 'same' concepts which are nevertheless decontested in different ways and therefore have different roles, positions and meanings within the morphology. Or, alternatively, that the 'same' ideologies may seek to decontest their concepts differently at different points in time and in response to different questions. Thus, the different ideologies of social democracy and liberal democracy might have the same conception of the concept of democracy within their structure (Dommett, 2012: 21), and these two ideologies may also change over space and time as a consequence of changes in their conception of democracy.

Freeden's morphological approach therefore simultaneously incorporates important insights from other theorists regarding the nature of ideology, while offering a clear and systematic approach for the analysis of ideology which can be replicated across different instances of ideologies, and across different expressions of the 'same' ideology at different spaces and times. The theory therefore lends itself well to 'mapping' the various ideological programmes for institutional change in national English town and country planning over time.

Freeden's approach has been developed for the analysis of particular ideologies, rather than ideology in general. While the morphological approach does of course come with an epistemology, this is not Freeden's primary focus. Instead, he has focused on developing a theory which allows for ideology to be clearly operationalised in researching particular ideologies. Heywood (2012: 4) has argued that "much confusion stems from the fact that, though obviously related, 'ideology' and 'ideologies' are quite different things to study". Although clearly based in a theory of ideology, it is important to recognise that Freeden's 
morphological conception primarily aids the analysis of the content of a certain type of political thinking, rather than the analysis of a certain type of political thinking in itself.

\subsection{The Ideology of the Institution of Planning}

The morphological approach has been developed to analyse instances of the main families of 'abstract' political ideologies such as liberalism, socialism and conservatism, yet the focus of the paper is on the relationship between situated instances of such ideologies and changes in the institution of national English town and country planning. It is therefore not the argument of this paper that planning is itself a political ideology, but that planning has arisen as an institution in relation to ideological argument and that subsequent planning reform can be seen as being partly a function of ongoing ideological contestation.

This way of thinking about the institution of planning draws upon insights from the 'ideational turn' in political science and discursive institutionalism in particular (Béland \& Cox, 2011a; Blyth, 2002; Schmidt, 2010). This school of new institutionalism sees institutions as constituting "crystallized ideas" (Blyth, 2002: 309). In other words, "ideas are embedded in the design of institutions" (Béland \& Cox, 2011b: 8). This 'turn to ideas' has arisen due to the difficulty within institutionalism in explaining institutional change, which arises from its innate structural bias: if an institution structures social and political relations and practices, how does agency overcome structure to succeed in adjusting the institution?

Analysts working with this approach therefore "take a more dynamic view of change, in which ideas and discourse overcome obstacles that...more equilibrium focused and static older institutionalisms posit as insurmountable" (Schmidt, 2008: 304). This is achieved by focusing not purely on material interests, nor on historical structures, but on how actors interpret (and create) interests and historical structures through ideas. The focus of such an analysis is therefore both ideas and the discourses in which they are communicated. Because of the ontological foundation of such an approach, which considers socially constructed political 'reality' as a distinct category to material 'reality' with its attendant 'brute facts', ideas and discourse become the mediators between them, the means by which the dialectical relations between the two are expressed. This "almost inevitably follows" from the acceptance of the view that the relationship between structure and agency is dialectical (Hay, 2002: 209).

Schmidt $(2008,2014)$ identifies three levels of idea which tend to be identified in discursive institutionalist analysis: philosophical ideas which are public philosophies and ideologies shaping policies and programs; programmatic ideas which are the organising assumptions underpinning policy ideas and which define the problems, issues to be considered, normative goals and the methods to be applied; and policy ideas which 
are specific policies or policy solutions. Institutionalist analysis tends to focus on the programmatic and policy levels of idea due to the abstraction and attendant difficulties of analysis which exist at the philosophical level. However, the morphological approach can be adapted to help us think about this philosophical, or ideological level of ideas in a more systematic way using analytical tools garnered from political theory, and therefore trace relationships with the programmatic and policy levels of ideas.

The theory underpinning this paper therefore holds that the institution of national English planning has been partly structured and adjusted by ideologies at the philosophical level of ideas. If political ideologies comprise a morphology of essentially contested concepts, and act to simplify and control political meaning, then the institution of planning will be a site for ongoing contestation as ideologies struggle for control over the meanings of those political concepts which are of core importance to planning. Change in planning therefore becomes partly a function of ideological competition over the proper meanings of the concepts which it shares with competing ideologies. Such competition will have implications for the programmatic and policy ideas embedded within the institution of planning at the political centre.

The task for the analyst is therefore to take an historical view and seek to identify those political concepts which are of structural importance to planning and are shared with political ideologies, and to identify how their meanings and relational morphology have changed over time. Through such an analysis, the latent ideological contestation which has been made manifest through the programmatic and policy ideas driving the Conservative-led Coalition planning reforms after 2010 may be more fully understood.

This form of analysis does not therefore seek to identify 'the ideology of planning'. Instead, it seeks to identify the ideology of the institution of planning. That is to say, through an analysis of the institutionalisation of various contested concepts at various points in time, the ideology (or ideologies) of the institution of national English town and country planning may therefore also be analysed. This will involve identifying concepts which have been of core importance to the institution of planning, and analysing how they have been decontested in the ideology of the institution. Of course, any decontestation can only be partial and temporary. Decontestation of core concepts in the ideology of the institution of national English town and country planning can only be 'more or less' successful because they are by their nature contested and therefore subject to change.

\subsection{Summary}

The analysis in this paper draws on Freeden's morphological conception of ideology and combines it with insights from discursive institutionalism in order to systematically analyse the relationship between 
concepts which are contested in competing political ideologies and institutional change in national English town and country planning.

In order to appreciate the nature of any contestation over the concepts shaping town and country planning today, it is helpful to take an historical view and trace the development of the institution of English planning over time and thereby identify which concepts have been adopted as part of planning and what have been the various ideological debates over their relationships and meanings and, therefore, the form the institution should take. In this way, it will also be possible to identify the conceptual legacies with which later ideologies have had to engage.

The remainder of this paper therefore examines two 'snapshots' in the history of English planning. The first is the institutionalisation of the English planning ideal in the late 1930s and 1940s, and the second is the institutional changes which occurred after the election of the Conservative-led Coalition government in 2010. These periods will be contextualised through discussions of developments in politics and planning in the periods leading up to these two 'snapshot' periods.

The morphological approach will be used to analyse the ideology of the institution of English town and country planning across the two historical 'snapshots'. A more discursive institutionalist form of analysis will then be used to 'drill down' in to the programmatic and policy ideas which have been shaped by the ideological level of ideas in the post-2010 Coalition government period in order to reveal some of the contradictions and complexities which a more abstract 'ideological' level of analysis struggles to incorporate. 


\section{The Ideological Context for the 1947 System}

The modern institution of English planning was established in the 1940s in the context of the second world war and its immediate aftermath. However, it had previously gone through a long period of gestation and had been the subject of a wide range of ideological argument. The following section therefore foregrounds the later account of the institutionalisation of English planning in the late 1930s and 1940s through an analysis of some of the key concepts comprising late nineteenth and early twentieth century social and political debate.

The following section is not therefore an analysis of the ideology of the early planning movement. Instead, it is an analysis of some of the disparate concepts which would later be assembled into an ideological structure through the process of state-led institutionalisation. It therefore draws concepts from the planning literature of the period, but also from wider political thought. The function of the following section is therefore to establish the terms of the ideological debate regarding the proper meanings of concepts which would be core to the emerging institution of English town and country planning in the 1930s and 1940s. It is important to appreciate the historical debates regarding these concepts because, as will be demonstrated, these would later influence how such concepts would be interpreted in subsequent periods of institutional change in English town and country planning.

The concepts which will be discussed are therefore those which can be argued to have resided at or near to the core of the ideology of the institution of planning. They have shaped the terms by which the institution of English town and planing was established, as well as the terms by which debates about later institutional change were conducted. These concepts include the state, liberty, property and society, as well as town and country. These concepts have been identified through an analysis of the relevant literature of the time, and by considering the degree to which debates about them have shaped the institution of English planning. The essentially contested concepts selected for analysis here are far from ideologically 'neutral'. Instead, they are subject to ideological contestation because they have the power to be so prescriptive. This is what makes them political (or ideological) concepts forming a crucial part of the political concept of 'planning'.

Of course, other concepts might have been selected. These could include 'sustainability' or 'public interest', for example. However, these concepts have arguably been of less fundamental importance to ideological debates about planning than those selected for this paper. Indeed, the concept of sustainability was a much later addition and has in any case been criticised as being more of an empty signifier which may act as a organising concept for wider ideological argument, rather than having much in the way of any substantive 
content of its own (for a review, see Brown, 2016). As for 'public interest', it is hard to justify how this could be an essentially contested concept in itself; like 'sustainability' it is more often used as an organising category which captures more fundamental disputes about the priority which should be given to competing ideological imperatives in decision-making.

However, it is important to again emphasise that the analysis conducted in this paper is not claiming exclusivity: arguments could be made regarding the ideological importance of a wide range of concepts. This paper is presented in an attempt to draw attention to this way of thinking about the relationship between ideology and planning and is not seeking to exclude different (and, one hopes, complementary) readings.

\subsection{Conceptual Debates in the Abstract}

The following section analyses the abstract ideological debates which formed part of the intellectual context of the social reform movements of the late nineteenth and early twentieth centuries. The analysis will show how different ideological positions assembled and sought to decontest concepts such as liberty, property and the state in different ways, so that: "[a]gitation for a betterment of the conditions of the poor was harnessed to all the major ideologies in turn" (Freeden, 1998: 199) but with different implications. There then follows an examination of some of the ways in which these debates manifested in town and country planning ideas and practice during this period.

\subsubsection{State, Liberty, Property and Society}

What would become known as the 'planning movement' developed against a background of debate between elites, parliamentary parties and the public about the proper relationship between the state, individual liberty and property in the late nineteenth and early twentieth centuries. A significant part of the debate was concerned with challenging the legacies of 18th and 19th century laissez-faire classical liberalism. Classical liberalism was suspicious of state interference in the market and private property because of the threat to individual liberty which it was thought to represent and because intervention in the market by the state was thought to be less efficient than 'natural' competition and so produces less desirable outcomes.

Freedom, in this sense, can be understood as freedom from constraint and coercion, a form of what Isiah Berlin would later classify as 'negative freedom' (Berlin, [1958] 2001). Under this conception, the state should not take responsibility for interfering in an individual's freedoms for the good of society, unless such freedoms directly threaten the freedom and safety of other individuals. For the state to be able to interfere in individual liberty for the good of the individual and wider society (rather than to prevent direct 
harm to others) would be to dangerously expand the concept of the self beyond the sovereign individual and bring with it the threat of authoritarianism.

However, this position came to be challenged from within by later reformist New Liberal thinkers such as T.H. Green (1836 - 82), J.A. Hobson (1858 - 1940) and L.T. Hobhouse (1864 - 1929), who were "essentially engaged in a project to redefine old liberal concepts and values in line with new political practice" (Leach, 2009: 43). Such reconsiderations were "cast at a political or moral rather than an economic level" (Barker, 1978: 17) and it was this shift of focus which created space for the concept of society, and through it the state, to assume a more central position in liberal thinking.

This repositioning of society and the state was linked to a move in New Liberalism to define liberty as being more than the classical freedom from constraint or compulsion. For T.H. Green, freedom meant "a positive power or capacity of doing or enjoying something worth doing or enjoying...a power which each man exercises through the help or security given him by his fellow-men" (Green, [1888] 2011: 371). Similarly, for L.T. Hobhouse, liberalism was concerned with fostering rational self-realisation and, through this, encouraging the rational self-realisation of others and thus strengthening a free society (Hobhouse, [1911] 1994a: 59).

We see here an attempted decontestation of the concept of liberty which transforms it from the sovereignty of the individual and their freedom from interference and coercion, to a more communal and positive conception of liberty which acknowledges the role of the individual in society and the individual's duty to express their liberty through rational self-development and, through this, foster the development of others in a community. In Berlin's terms this is a 'positive' conception of liberty (i.e. 'freedom to') which meant acknowledging the existence of social injustices which prevent the self-development of individuals in society.

It was therefore not so sceptical of state intervention as classical liberalism and its more 'negative' conception of liberty, as it was recognised that the state would have a useful (if limited) role to play in removing barriers to communal self-development, even if some individuals might consequentially suffer from some increased constraint. Yet this could be justified by the fact that the existing distribution of freedom was unequal. This two-way dilemma was recognised by Hobhouse: "Unfortunately what is liberty for one man is often the negation of liberty for another" (Hobhouse, [1913] 1994b: 181). 
An aside here is necessary regarding Berlin's distinction between positive and negative liberty. As has been influentially argued by MacCallum (1967), the positive/negative liberty distinction can be seen as introducing a false dichotomy because in both conceptions the individual agent is both free from something and is free to do something. The difference lies in what the individual is free from and free to do. MacCallum therefore argues that freedom should be more properly considered as a 'triadic relation' or a relation between three things: "an agent, certain preventing conditions and certain doings or becomings of the agent" (Carter, 2003: 9). This is a powerful critique, but nevertheless the distinction between positive and negative liberty remains helpful because it points to general differences regarding what counts as a constraint. For the New Liberals, constraint includes social and economic inequalities and this implied a role for redistributive state power to help create the conditions in which individuals and communities have more equal opportunities to develop.

The idea that the state should serve as an agent of the whole community brings New Liberalism's conception of liberty close to socialism's ideal, with the exception of guild socialism which had a much more ambivalent attitude to the state. This similarity was acknowledged by Hobhouse when he wrote: "The two ideals, as ideals, are not conflicting but complementary" (Hobhouse, 1905: 228-9 as quoted in Barker, 1978: 21). Hobson argued that "Liberalism is now formally committed to a task which certainly involves a new conception of the State in its relation to the individual life and to private enterprise" but was keen to point out that this was not "Socialism in any accredited meaning of the term, though implying a considerable amount of increased public ownership and control of industry" (quoted in Eccleshall, 1986: 204). For Hobson, the new liberalism meant "a fuller realisation of individual liberty contained in the provision of equal opportunities for self-development" (quoted in Eccleshall, 1986: 204 - emphasis added).

Like socialists, New Liberals therefore related the concept of liberty with that of equality, but with different implications. Equality of opportunity would require a very different form of state activity to the kind of social equality promoted by socialists, for whom "the redistribution of wealth was one chief form through which the concept of equality was construed" (Freeden, 1998: 431). Indeed, while there may have been broad agreement across the New Liberal / socialist ideological divide regarding the general desirability of a more equitable distribution of liberty through society, the precise articulation of this distribution and the means by which it should be secured remained areas of contestation.

For some socialists, for example, equality was to be secured through the redistribution of property and the common ownership of the means of production. This position was famously expressed through Clause III (later to become Clause IV) of the Labour Party's original 1917 constitution: 
"To secure for the producers by hand or by brain the full fruits of their industry, and the most equitable distribution thereof that may be possible, upon the basis of the common ownership of the means of production and the best obtainable system of popular administration and control of each industry or service."

(as quoted in Pelling \& Reid, 1996: 39)

For the Labour Party and the Fabian socialists active in its formation, such common ownership would be secured through the state which as a concept was brought into close proximity to that of society. Indeed, Ramsay MacDonald (1866 - 1937) who would become the first Labour Party prime minister wrote: "the Socialist considers that the State is as essential to individual life as is the atmosphere, and he regards the evolution of political democracy as having been necessary in order to create a state which could respond to the common will" (as quoted in Freeden, 1998: 447). The state is decontested here as being an expression of communal will and, as such, occupies very similar conceptual space as the socialist concept of society.

For such state socialists, the state, when peopled by disinterested experts with access to scientific knowledge and professional training, would promote collectivism and equality as it would be a more equitable means of distributing property and resources than that achieved by private enterprise (Leach, 2009: 109). There was therefore a general trend in state socialism towards centralised state power. This paternalistic concentration and growth of state power, administered by experts, was problematic for New Liberals, who objected to the potential for such power to limit individual freedom. For Hobhouse, the expert "sometimes looks strangely like the powers that be...who at the outset was the Socialist's chief enemy" (Hobhouse, 1905: 230, quoted in Barker, 1978: 21).

The centralised state socialist position can be contrasted with more dispersed guild socialism which instead emphasised common ownership through a guild or syndicate. Such a position was partly inspired by the communal anarchism of William Morris (1834 - 1896) and Pyotr Kropotkin (1842 - 1921) who both opposed the institutions of government, the state and traditional conceptions of private property. Kropotkin was a major contributor to English political discussions of the time (Barker, 1978: 72). He believed in the commune as the chief social unit of society, which for him should comprise a network of such communes "knowing neither frontiers or walls", grouped by a "commune of interests whose members are scattered in a thousand towns and villages" (Kropotkin, as quoted in Barker, 1978: 73). Morris favoured the end of commerce, and advocated spontaneous self-management. This would be accompanied by a 'joy in the natural world' and a 'joy in natural work' whereby workers would own the fruits of their labour. 
We see here how in these debates the concept of property is intimately linked with the concepts of liberty, society and the state and the proper form of political and communal organisation. For different ideological reasons state intervention could be justified if it was intended to promote the ideal of positive liberty and greater equality throughout society. This pointed to social and economic reforms, such as progressive taxation, old age pensions, school meals, and land reform. Indeed, it is in debates about the 'land question' that we can see most clearly the contestations regarding liberty, society and the state as they relate to property in a form which is of clear relevance to English town and country planning.

\subsubsection{Liberty, Property, the State and the Land Question}

Private property in land was a significant area of debate during the late nineteenth and early twentieth century era of progressive social reform. Indeed, private property in general has a long ideological history, with liberal and conservative theorists being its most "committed defenders" (Heywood, 2015: 299). Both the classical liberal defence of private property and the arguments for radical land reform are paradoxically influenced by the thought of English Enlightenment philosopher John Locke (1632 - 1704). Locke was concerned with the problem of how the unequal distribution and ownership of private property could be justified when God had initially "given the world to men in common" (Locke, [1690] 2001: 13).

Locke reasoned that every individual owns their own person (has their 'property') and when such a private individual labours in the world, they mix their labour (a manifestation of their property) with the fruits of their labour, and through this transmutation appropriates these fruits from the commons (Locke, [1690] 2001: 13). Because the appropriator was now said to own that with which they had mixed their labour, they had the right to exchange, sell or otherwise alienate it as they so wished. For Locke, this argument could be extended to justify enclosure of common land, and its transmutation into private property. For Locke, land could be owned privately as long as it was cultivated and used productively. As soon as it was left uncultivated (i.e. as soon as human labour ceased to be mixed with it), it returned to the commons. Land could therefore logically only be cultivated for the good of the commons if it was privately owned i.e. if the land and its fruits were mixed with human labour which is understood here as being the private property of individuals.

Of course, as Ryan (2012: 479) argues "the difficulty comes when all the readily acquired land has been acquired and there are landless persons without access to uncultivated land". In this instance, the landowner must employ labour on fair terms. The further problem then arises that these labourers do not actually own the fruits of their labour: "it seems the landlord owns without working while his labourers work without 
owning" (Ryan, 2012: 479). It was this tension which formed the basis of agrarian radicalism for the next three centuries, and is important context to the debates over 'the land question' in the late nineteenth and early twentieth centuries.

It was this association of property with liberty that prompted the libertarian philosopher Herbert Spencer (1820 - 1903) to advocate land nationalisation, which he supported on the basis that by returning privatelyowned land to the commons, a great redistribution of liberty could be secured:

"The change required would simply be a change of landlords. Separate ownership would merge into the joint-stock ownership of the public...A state of things so ordered would be in perfect harmony with the moral law. Under it all men would be equally landlords; all men would be alike free to become tenants...Clearly, therefore, on such a system, the earth might be enclosed, occupied and cultivated, in entire subordination to the law of equal freedom."

(Spencer as quoted in George, [1881] 2011: 363)

The above passage was quoted favourably by American liberal economist and philosopher Henry George (1839 - 1897) in Progress and Poverty (1881), his hugely popular and influential book on what he perceived to be the injustice of private property in land. For George, private property in land itself (i.e. excluding alienable products of cultivation or structures built upon land) could not be justified as it has already been created by God (George, [1881] 2011: 302). There was, therefore, a "natural and inalienable right to the equal use and enjoyment of land" (George, [1881] 2011: 305). Private property in land was therefore a great injustice: "The necessary relation between labor and land, the absolute power which the ownership of land gives over men who cannot live but by using it, explains what is otherwise inexplicable - the growth and persistence of institutions, manners, and ideas so utterly repugnant to the natural sense of liberty and equality" (George, [1881] 2011: 315).

George's proposed solution was a 'single tax' in land, which would replace all other forms of taxation. Existing patterns of land ownership would remain unaltered, but what would be appropriated would be the right to economic rent of land: "In this way, the State may become the universal landlord without calling herself so, and without assuming a single new function" (George, [1881] 2011: 363). Crucially, this would result in a transformation of social consciousness:

"The dangerous classes politically are the very rich and very poor. It is not the taxes that he is conscious of paying that gives a man a stake in the country, an interest in its government; it is the 
consciousness of feeling that he is an integral part of the community; that its prosperity is his prosperity, and its disgrace his shame. Let but the citizen feel this; let him be surrounded by all the influences that spring from and cluster round a comfortable home, and the community may rely upon him, even to limb or to life."

(George, [1881] 2011: 383 - 384)

George's ideas were hugely influential at the time, prompting Hobson to write in 1897 that: "Henry George may be considered to have exercised a more directly powerful formative and educative influence over English radicalism in the last fifteen years than any other man" (Hobson, 1897: 844). Hobson argued that George's success lay in his ability to "drive an abstract notion, that of economic rent, into the minds of a large number of 'practical' men, and to generate therefrom a social movement" (Hobson, 1897: 837). Ebenezer Howard (1850 - 1928), who in 1882 heard George lecture and then read Progress and Poverty (Buder, 1969: 391), was one such 'practical man'.

\subsubsection{Liberty, Property, State, Society and the Conservative Mind}

The association of property with liberty is also present in conservative thought. Heywood argues that property is an asset "that possesses a deep and, at times, almost mystical significance for conservatives" (Heywood, 2012: 77). However, this association was predicated upon a different conception of liberty. For liberals and New Liberals in particular, private property and liberty were closely connected because it was through the stability created by private property that the individual could be free to rationally self-cultivate and develop the wider community for the common good. For a Tory conservative, land ownership and liberty were associated for more paternalistic reasons.

In 1872 Benjamin Disraeli (1804 - 1881) wrote that: "The liberty of England depends much upon the landed tenure of England - upon the fact that there is a class which can alike defy despots and mobs, around which the people may always rally, and which must be patriotic from its intimate connection with the soil" (quoted in Gilmour, 1977: 79). Landed property therefore "produced obligations as well as rights" (Gilmour, 1977: 80). Landowners therefore had a paternal duty conferred by the power and privilege of land ownership to be the warders of liberty. Private property is also thus a key means by which an overly-powerful state could be kept at bay.

However, it was this Disraelian form of Tory paternalism, or 'One Nation' Toryism, which allowed some conservatives to countenance some degree of state intervention in the interests of social reform, manifested through a strong and paternalistic style of government which would be run by the upper classes for the 
'general good'. Although having apparently similar implications for the role of the state, the underlying logic of this paternal conservative argument is very different to that of the New Liberals or the state socialists.

Conservatives had long defended a liberal Whiggish laissez-faire approach to the economy and had opposed the expansion of the state into private interests (Dorey, 2011). However, Disraeli and conservatives like him were troubled by what they saw as the two divided nations in England: the rich and the poor. Although no doubt moved by compassion, Disraeli also saw such social division as a threat to the stability of England and therefore state-led social reform could be justified in order to create 'one nation' and also improve electoral support for the Conservative Party following the Representation of the People Act 1867 which had enfranchised part of the male working class. Crucially, however, this one nation would not comprise equals, but would comprise an unequal society which allowed for advancement. One Nation conservatism, therefore, "firmly believes that the gap between rich and poor, although entirely natural and inevitable, should nonetheless be kept within limits" (Dorey, 2011: 49).

The conservative understanding of individuals being obligated to others in a community involved a conservative recognition of the value of society as the natural 'home' for individuals (Heywood, 2012: 75). In classical British conservatism (as with some forms of liberalism), acquisitiveness and self-interest are natural characteristics of human beings, yet conservatives "do not perceive an intrinsic or inevitable contradiction between the individual acquisitiveness and societal benefit" (Dorey, 2011: 9). However, the concept of society is here understood in a traditionally conservative form of the 'organic society'. This is a vision of society that is steeped in a respect for history and tradition, and therefore sees the existing structures and institutions of society as having arisen 'naturally' or 'organically' and therefore valuable in their own right and to be conserved. This suggests a deep suspicion within conservatism of human rationality and any attendant 'grand theories' regarding the proper form of society such as those offered by liberalism and socialism (see Oakeshott, [1947] 1991).

For a conservative, society is too complex to be fully understood by the human mind and, therefore, planned. Traditional institutions such as family, marriage and the nation are therefore to be valued and conserved as important social structures which maintain stability, civility and offer the individual a sense of identity and a knowledge of their place in the world. So while a One Nation conservative might believe that the rich have a duty to the poor, and therefore a duty not to stand in the way of progressive social change, they also believe that social change ought to occur "organically and incrementally" (Dorey, 2011: 7). It is also due to this understanding of society and the limits of human reason that the great 'conservative virtue' of pragmatism and 'common sense' arises. 
We have seen in this brief overview of the relevant intellectual debates of the period, that "the great modern ideological families all share some blood ties" (Freeden, 1998: 459). None of the concepts discussed are exclusive to liberalism, socialism or conservatism, yet they are contested in different ways and in association with different clusters of concepts. Crucially, we see how through an overlap of New Liberal, One Nation conservative and state socialist thought, there is the potential for an expansion in state power and intervention into the private lives and property of individuals, in order to secure greater justice for the poor and the landless. Of course, there would remain significant disagreement regarding the proper form of such intervention, and therefore the precise means by which such justice could be secured.

\subsection{Conceptual Debates in Early English Town and Country Planning}

The following section analyses the manifestation of abstract ideological debates in more concrete English town and country planning ideas and practice in the late nineteenth and early to mid twentieth centuries. It also foregrounds some of the ideologically-loaded concepts which are more uniquely the concern of planning, such as 'town' and 'country'.

\subsubsection{Town, Country, State, Liberty, Property and Society}

In 1897, New Liberal philosopher J.A. Hobson described the context in which Henry George's Progress and Poverty (1881) was published in England:

"The phenomenally rapid growth of large industrial towns, with their close concentration of working population, the direct and obvious result of our free trade policy, had been quickly ripening the land question in the towns, and the rising standard of sanitation and of other civic needs was driving home to municipal reformers a sense of conflict between the public interest of the town and the private interests in the owners of the land."

(Hobson, 1897: 839)

It was this 'sense of conflict' between public and private which helped birth the modern planning movement. The general climate of social reform thus manifested in the towns through a growing awareness of the plight of the urban poor who were victims of rapid industrialisation and urbanisation fuelled by the collapse of the rural economy and the 'flight from the land' during the 1870s (Nair \& Poyner, 2006: 168). This was linked with the 'discovery of poverty' as being partly a function of economic circumstance (and laissez-faire) rather than simply indolence, a fact that was driven home by the major depression in trade 
and industry suffered by Britain in the 1880s (Hall, 2002). These realisations, combined with the ongoing 'land question' intersected to produce a preoccupation with urban physical living conditions and health which were of such significance to the early English planning movement.

The reformers of the period therefore associated the concept of the town with squalor, illness and degradation, and the town "became associated in the minds of many upper- and middle-class citizens with disorder, moral depravity, [and] questionable business activity" (Foley, 1962: 13). This concept of the town as the dark side of laissez-faire industrialisation came to be linked and contrasted with a mythical and spiritual concept of the countryside which had its roots in English Romanticism.

Ditt \& Rafferty (1996) show how the rationalists of the Enlightenment (who were a considerable influence on English classical liberalism) emphasised the power of human reason and the duty to cultivate and thus tame nature for the development of mankind. They thereby "laid the ideological foundations that made possible the unrestrained exploitation of natural resources for the free development of the market and specifically for industrialisation" (Ditt \& Rafferty, 1996: 1). The late nineteenth century's critics of modernity responded by invoking the spirit of the Romantics in their critique of urbanisation and materialism, arguing for the conservation of the wilderness and the rural way of life which were for them "not just symbols of originality, beauty and health, but were also part of the 'national character"' (Ditt \& Rafferty, 1996: 1). Stevenson describes this as the cultural (and ideological) construct of 'deep England' which flourished from the 1880 s as reflected in "an often nostalgic reaffirmation of pastoral and ruralist themes in the face of industrialization and urbanization" (Stevenson, 2005: 192).

The problem of rural over-crowding and the depletion of the population of country districts is identified in the opening pages of Howard's Garden Cities of Tomorrow (1902) as being a "subject...universally regarded as of extreme importance", and the key to the problem, he argued, was to "restore the people to the land" (Howard, [1898] 1902: 13). It was the land, and its marriage with the town, that would "pour a flood of light on intemperance, of excessive toil, of restless anxiety, of grinding poverty" (Howard, [1898] 1902: 13). Howard's subsequent description of the results of this marriage exhibit a clear preoccupation with the promotion of the social welfare of its inhabitants. This was to extend across socio-economic classes, as "it is but just and right that...more helpless brethren should be able to enjoy the benefits of an experiment which is designed for humanity at large" (Howard, [1898] 1902: 27).

Indeed, much of Garden Cities of Tomorrow is devoted to explaining how the revenue from the increment in the value of property in land held in trust would be generated and spent for the benefit of the community. 
This reflects Howard's rejection of land nationalisation. His vision did not require the wholesale expropriation of land by the state, or the proletariat. Indeed, he objected to the "attempt to throw the whole blame of and punishment for the present deplorable condition of society on to a single class of men [landlords]" (Howard, [1898] 1902: 124). His proposed solution required that "the people in their collective capacity own the land" (Howard, [1898] 1902: 130 - emphasis in original), and not the state. In these early days of planning thought, then, there was no requirement for large-scale state intervention in property and individual liberty. Property would still be in private (rather than state) ownership, but held in common for the community living on it, and it was this that would form the foundation for a free society.

In Howard's work we see an ambivalent attitude to towns and industry as they then existed. However, Howard did not simply romanticise the country, but rather analysed its strengths and weaknesses in the same way as he did that of the town: "The Country...declares herself to be the source of all beauty and wealth; but the Town...mockingly reminds her that she is very dull for lack of society, and very sparing in her gifts for lack of capital" (Howard, [1898] 1902: 16). He therefore concluded that: "Town and country must be married, and out of this joyous union will spring new hope, a new life, a new civilisation" (Howard, [1898] 1902: 18 - emphasis in original). This mystical ‘joyous union' of 'Town-Country' would therefore combine the strengths of both and be "free from the disadvantages of either" (Howard, [1898] 1902: 16). For Howard, then, town and country could complement one another, and their synthesis would the foundation for a new society.

This sentiment was shared by biologist, sociologist and influential planning visionary Patrick Geddes (1854 - 1932) (Geddes, 1915: 88). Geddes argued for the conservation of nature, of the country, "Not merely on grounds of amenity, of recreation" but also "In terms of the maintenance and development of life... and further, of that arousal of mental life in youth, of its maintenance through age, which must be the aim of higher utilitarianism" (Geddes, 1915: 94). Geddes is here arguing for nature and the countryside as being at the very foundation of the kind of positive liberty as expressed through personal and communal development and cultivation which was advocated by some New Liberals.

But, according to Geddes, "the children, the women, the workers of the town can come but rarely to the country. As hygienists, and utilitarians, we must therefore bring the country to them" (Geddes, 1915: 96). This much Geddes shared with Howard, but as argued by Hall (2002: 154), Geddes was thinking bigger, on the regional level. To this effect, he criticised urban sprawl: "Towns must now cease to spread like expanding ink-stains and grease spots: once in true development, they will repeat the star-like opening of the flower, with green leaves set in alteration with its golden rays" (Geddes, 1915: 97). For Geddes, then, 
towns and cities were associated with the oily effluence of industry, and were contemporary manifestations of Blakean 'dark Satanic Mills'.

Indeed, such was the anxiety about encroaching urbanisation from within the crystallising planning ideology during the inter-war period, that there was an hardening of opinion concerning the relationship between town and country. Thomas Sharp (1901 - 1978) and Patrick Abercrombie (1879 - 1957), both influential figures in the inter-war planning movement, expressed concern at the potential bleeding together of town and country in a manner which had been so vehemently critiqued by architect-planner Clough Williams-Ellis (1883 - 1978) in his polemic England and the Octopus (1928), with its description of "disfiguring little buildings [that] grow up and multiply like nettles along a drain, like lice along a tapeworm" (Williams-Ellis, 1928: 141, as quoted in Hall, 2002: 81).

Abercrombie in his Town and Country Planning (1943) was keen to emphasise that there should be no attempt by the planner "at a fusion or confusion between the two: town should be town and country should be country; urban and rural can never be interchaneable adjectives" (Abercrombie, 1943: 177). Similarly, Sharp argued that "the very words town and country comprise one of the most violent antitheses in the language" (Sharp, 1945: 29 - emphasis in the original), and pleaded for the maintenance of "the old sharp physical distinction between town and country, instead of driving great wedges of suburbia between them" (Sharp, 1945: 41). However, this was not to say that Sharp and Abercrombie entirely rejected Howard's vision. Sharp maintained that a "new balance between town and country must be struck... Town and country are not two organisms but parts of one organism. They are two related utilities making the one great synthesis of natural life" (Sharp, 1945: 92). Similarly, Abercrombie spoke favourably of Howard and his 'third magnet' of 'Town-Country': "There is, then, no fear about allowing an interchange of motives between [town and country], so long as their identity is maintained" (Abercrombie, 1943: 177).

By the time the second edition of Abercrombie's Town and Country Planning (1943) was published, the planning movement had crystallised into a profession and an area of government policy. The Town Planning Institute (now the Royal Town Planning Institute) had its inaugural meeting in 1913 (Ashworth, 1954: 193), and the growth of the influence of such professionals 'suppressed the radical intent' of Howard's ideas within the Garden Cities and Town Planning Association (“GCTPA”) (Hardy, 1991: 213). The GCTPA gradually came to accept the need for greater state intervention to deliver garden cities over the 1920s and 1930s. By the time of the appointment of the Royal Commission on the Distribution of the Industrial Population ("the Barlow Commission") in 1937: “Any doubts about the role of the State were 
finally expunged" (Hardy, 1991: 199). By 1943 Abercrombie (who was a member of the Barlow Commission and a longstanding member of the GCTPA) could claim that:

"If the country has been humanly modelled and planned in the past, the need for a continuance of the practice is even more obvious to-day. The only real change is in the personnel that does the work: there are those that think it can still safely be left to the big landowners and their descendants, the little ones but this is a fallacy that scarcely needs exploding: somebody with as wide or wider area of control than the great landowners must step in - either the State or the Local Authorities.” (Abercrombie, 1943: 199 emphasis added).

We see here an assumption that proper planning could only be delivered through state intervention with the state here understood as a benevolent institution acting for the common good rather than for individual and private interest.

\subsection{Summary}

This section has discussed some of the political concepts which were the focus for contestation across various political ideologies in terms of their engagement with questions of social reform in the late nineteenth and early twentieth centuries. It has also examined the manifestation of these concepts in the early planning movement of the period, as well as debates within this movement which touched on concepts more uniquely the concern of planning such as the relationship between town and country.

But do such concepts comprise an ideology? As presented here, the answer is no. They have not been described in terms of their specific articulation into an ideology and the consequent exertion of interpretative power on each other. It has been important to identify the key contested concepts in early planning thought so that we may identify precisely how they have been contested (and added to) since. The next step is to judge how this process occurred in the formal institutionalisation of English planning in the 1930s and 1940s, which is the focus of the next section. 


\section{The Institutionalisation of National English Town and Country Planning}

This section gives an account of the institutionalisation of English town and country planning in the late 1930s and 1940s. It will be shown that it was through this process that the contested concepts comprising part of the intellectual and historical context in the period leading up to the Town and Country Planning Act 1947 ("1947 Act") were formally (and of course only partially) decontested and structured into an ideology of an institution. That is not to say that their 'meanings' were comprehensively fixed through this institutionalisation, but rather that they were controlled to the extent that they provided a formal and relatively stable ideological framework which shaped and legitimised the national institution and practice of planning.

While the 1947 system was indeed the first time that town and country planning was institutionalised into a relatively comprehensive and coherent form which is still recognisably in use today, there were a number of important examples of institutionalisation of town planning ideas throughout the first half of the twentieth century. Indeed, such was the activity that the report of the Royal Commission on the Distribution of the Industrial Population ("the Barlow Commission") was in 1940 able to evoke the same visionary spirit as Howard and Geddes with the claim that: "Economists and town planners have fought side by side for the last half century to make England, if not the New Jerusalem of Blake's poem, at any rate a fairer and sweeter country" (Barlow, 1940: 9).

The Housing, Town Planning Etc. Act had been enacted in 1909 and was the first piece of legislation with town planning provisions. This was followed by a number of other Acts before 1940, including the Town and Country Planning Act 1932 ("the 1932 Act") which gave local authorities the power (but did not compel them to) to make 'planning schemes' "with respect to the development and planning of land, whether urban or rural" with powers to enforce and carry in to effect schemes, and to "provide for the protection of rural amenities and the preservation of buildings and other objects of interest of beauty" (Town and Country Planning Act 1932: 1), and the Restriction of Ribbon Development Act 1935.

However, by 1 April 1939, only 2\% of Great Britain's total area was covered by approved planning schemes (Barlow, 1940: 108) partly because local authorities were reluctant to incur costs associated with the requirement to pay compensation to landowners whose land was injuriously affected by such schemes and any associated injurious enforcement action, in the context of complex and difficult-to-implement provisions for local authorities to recover betterment (i.e. the increase in the value of property deriving from the provisions of a planning scheme and/or the efforts of the wider community). Furthermore, planning 
schemes were more regulatory than positive and there was no central government ministry with responsibility for overseeing and directing planning issues. There was therefore, as yet, no comprehensive institutional and national vision for positive planning, prompting Abercrombie to comment: "The net results... of thirty years of planning powers have been extremely disappointing” (Abercrombie, 1943: 172).

We will now see how this fragmented, 'local' picture of statutory regulatory planning was replaced by a more comprehensive, centralised and positive institution through the structuring of core concepts in the ideology of the institution of national English town and country planning in the 1940s. The discussion will focus on a small number of key reports and Acts of Parliament which were of crucial importance to the nascent institution of English town and country planning of the time. These are summarised in Table 1, along with some other key planning events of the period.

Table 1: The 1947 System - Select Reports and Acts

\begin{tabular}{|c|c|c|}
\hline Event & Summary of Scope & $\begin{array}{l}\text { Summary of Key Recommendations / } \\
\text { Provisions }\end{array}$ \\
\hline \multicolumn{3}{|l|}{$\begin{array}{l}\text { National (coalition) } \\
\text { Government Formed } \\
(1940)\end{array}$} \\
\hline $\begin{array}{l}\text { Report of the Royal } \\
\text { Commission on the } \\
\text { Distribution of the } \\
\text { Industrial } \\
\text { Population } 1940 \\
\text { ("Barlow report") } \\
\text { (Barlow, 1940) }\end{array}$ & $\begin{array}{l}\text { To inquire into the geographical } \\
\text { distribution of industry, what } \\
\text { disadvantages may arise from } \\
\text { concentration, and to report on } \\
\text { remedial measures. }\end{array}$ & $\begin{array}{l}\text { Recommended that the location of } \\
\text { industry should be influenced by the } \\
\text { state in order to deliver planned } \\
\text { decentralisation, overseen by a central } \\
\text { authority. Also recommended that the } \\
\text { government should appoint a panel of } \\
\text { experts to investigate the question of } \\
\text { compensation and betterment, and } \\
\text { control of development. }\end{array}$ \\
\hline $\begin{array}{l}\text { Report of the } \\
\text { Committee on Land } \\
\text { Utilisation in Rural } \\
\text { Areas } 1942 \text { ("Scott } \\
\text { report") (Scott, } \\
\text { 1942) }\end{array}$ & $\begin{array}{l}\text { To report on land utilisation in rural } \\
\text { areas, having regard to the well- } \\
\text { being of rural communities and the } \\
\text { preservation of rural amenities. }\end{array}$ & $\begin{array}{l}\text { Given that good agricultural land is a } \\
\text { key asset (especially in wartime), the } \\
\text { report recommended that the amenity } \\
\text { and productive value of the countryside } \\
\text { should be protected through a } \\
\text { compulsory local planning system } \\
\text { which extends across the whole } \\
\text { country. }\end{array}$ \\
\hline $\begin{array}{l}\text { Final report of the } \\
\text { Expert Committee on } \\
\text { Compensation and } \\
\text { Betterment } 1942 \\
\text { ("Uthwatt report") } \\
\text { (Uthwatt, 1942) }\end{array}$ & $\begin{array}{l}\text { To "make an objective analysis of } \\
\text { the subject of payment of } \\
\text { compensation and betterment in } \\
\text { respect of public control of the use } \\
\text { of land" (Uthwatt, 1942), in } \\
\text { accordance with the } \\
\text { recommendation of the Barlow } \\
\text { report. }\end{array}$ & $\begin{array}{l}\text { Recommended the nationalisation of } \\
\text { development rights in undeveloped } \\
\text { land, to be purchased by the state when } \\
\text { development was to set to occur; land } \\
\text { was then to be leased back at } \\
\text { development value if the development } \\
\text { was private so that betterment would be } \\
\text { retained by the state. Also } \\
\text { recommended that planning control be }\end{array}$ \\
\hline
\end{tabular}




\begin{tabular}{|c|c|c|}
\hline Event & Summary of Scope & $\begin{array}{l}\text { Summary of Key Recommendations / } \\
\text { Provisions }\end{array}$ \\
\hline & & $\begin{array}{l}\text { compulsorily implemented in built up } \\
\text { areas and proposed a periodic } \\
\text { 'betterment charge' be imposed on a } \\
\text { proportion of increases in annual site } \\
\text { values of developed land. }\end{array}$ \\
\hline $\begin{array}{l}\text { Interim Development } \\
\text { Act } 1943\end{array}$ & & $\begin{array}{l}\text { Made the preparation of 'planning } \\
\text { schemes' compulsory, thereby bringing } \\
\text { all land under potential planning } \\
\text { control for the first time. }\end{array}$ \\
\hline $\begin{array}{l}\text { The Control of Land } \\
\text { Use White Paper } \\
\text { (1944) }\end{array}$ & $\begin{array}{l}\text { To set out an outline scheme which } \\
\text { would provide the "basis for a } \\
\text { practical system whereby } \\
\text { individual rights of land tenure may } \\
\text { be reconciled with the best use of } \\
\text { the land in the national interest" } \\
\text { and thus take the opportunity } \\
\text { presented by "the collaboration of } \\
\text { all Parties in a National } \\
\text { Government" for "finding some } \\
\text { common measure of agreement on } \\
\text { a question which has in the past } \\
\text { divided political opinion." (MTCP } \\
\text { \& SSS, 1944) }\end{array}$ & $\begin{array}{l}\text { Officially confirmed the government's } \\
\text { acceptance that 'the community' had } \\
\text { the right to determine whether or not } \\
\text { development should take place. } \\
\text { Confirmed the government's intention } \\
\text { to: } \\
\text { - introduce a universal } \\
\text { requirement to obtain planning } \\
\text { permission; } \\
\text { - introduce a betterment charge; } \\
\text { - pay compensation for the } \\
\text { acquisition of development } \\
\text { rights; } \\
\text { - establish a central Land } \\
\text { Commission which would pay } \\
\text { compensation and collect the } \\
\text { betterment charge. }\end{array}$ \\
\hline $\begin{array}{l}\text { Town and Country } \\
\text { Planning Act } 1944\end{array}$ & & $\begin{array}{l}\text { Created compulsory purchase powers } \\
\text { for the acquisition and planning of land } \\
\text { in bomb-damaged and blighted areas. } \\
\text { Introduced the listing of buildings of } \\
\text { architectural or historic interest. }\end{array}$ \\
\hline \multicolumn{3}{|l|}{$\begin{array}{l}\text { Labour Government } \\
\text { Elected (1945) }\end{array}$} \\
\hline $\begin{array}{l}\text { Distribution of } \\
\text { Industry Act } 1945\end{array}$ & & $\begin{array}{l}\text { Created powers to control the provision } \\
\text { of industrial development in order to } \\
\text { secure proper redistribution of industry. } \\
\text { Required industrialists to report the } \\
\text { location of any new industrial buildings } \\
\text { of more than } 10,000 \text { sqft to the Board } \\
\text { of Trade prior to development. }\end{array}$ \\
\hline $\begin{array}{l}\text { Final report of the } \\
\text { New Towns } \\
\text { Committee 1946 } \\
\text { ("Reith report") } \\
\text { (Reith, 1946) }\end{array}$ & $\begin{array}{l}\text { To consider issues around the } \\
\text { establishment of New Towns in } \\
\text { furtherance of a policy of planned } \\
\text { decentralisation. }\end{array}$ & $\begin{array}{l}\text { Proposed a broad set of } \\
\text { recommendations around planning } \\
\text { principles, design, infrastructure, social } \\
\text { issues, organisation and governance of } \\
\text { New Towns (and extensions to existing } \\
\text { towns). }\end{array}$ \\
\hline
\end{tabular}




\begin{tabular}{|l|l|l|}
\hline Event & Summary of Scope & $\begin{array}{l}\text { Summary of Key Recommendations / } \\
\text { Provisions }\end{array}$ \\
\hline New Towns Act 1946 & $\begin{array}{l}\text { Provided for the creation of New } \\
\text { Towns by means of Development } \\
\text { Corporations. }\end{array}$ \\
\hline $\begin{array}{l}\text { Town and Country } \\
\text { Planning Act 1947 }\end{array}$ & $\begin{array}{l}\text { Nationalised development rights in all } \\
\text { land; reduced planning authorities from } \\
1,441 \text { to 145 in England and Wales; } \\
\text { introduced a 100\% betterment charge } \\
\text { on private developers; introduced a } \\
\text { system of discretionary development } \\
\text { control nationally. }\end{array}$ \\
\hline
\end{tabular}

(Source: Cullingworth, 1975a; Ward, 2004)

\subsection{Crossing the Rubicon to a 'Common Opinion'}

The second world war entangled the concept of liberty with that of the state, and thereby brought an otherwise abstract concept sharply into focus. As if in acknowledgement of this, the Labour Party manifesto of 1945 stated: "Freedom is not an abstract thing. To be real it must be won, it must be worked for" (Labour Party, 1945). In a very real sense, the liberty of the entire country had been threatened and the state had responded by extending its powers in order to ensure its continued survival. For Labour, such powers had stood "for order as against the chaos" of a lack of public control (Labour Party, 1945). It was during this period, therefore, that the "roots were firmly placed" for the so-called 'post-war settlement' (Dutton, 1997: 26), and the English town and country planning system institutionalised into a form we still recognise today.

The 'post-war settlement' refers to a broad consensus between the Labour and Conservative Parties of the time regarding the adoption of government intervention in the economy in the form of Keynesian economic management, the welfare state and, indeed, town and country planning. This view of history is not without its critics, some of whom deny that such a consensus ever existed (Pimlott, in Pimlott et al, 1989). For now it is sufficient to acknowledge such doubts while reiterating that, even though there surely remained ideological and policy disputes between the parties in this period, it is indeed the case that "after the end of the Second World War the political parties operated within a given framework, a set of generally accepted parameters in which certain key assumptions were shared and in which policy options were consequently limited" (Dutton, 1997: 9). As we shall see, one policy area within which options were thus limited was town and country planning, to the extent that a 1941 editorial in The Economist magazine remarked: "Control of the development of rural land and the re-development of urban sites; and the establishment of a balance between town and country, light and heavy industries and residential needs...[is] common 
opinion...It would be churlish to underestimate the advance which the new attitude represents. The rubicon has been crossed" (Editorial, 1941: 96 \& 98).

How and why such a consensus arose is open to debate. However, a shift towards increased state intervention had been precipitated by the "glaring internal problem of unemployment and regional imbalance in Britain" and "the growing acceptance of planning in the context of the major economic and political changes produced by the Second World War" (McKay \& Cox, 1979: 29). There was a concurrent growth in the "belief in the state's capacity to reduce social injustice and, by expanding the economy, to create a better life for the whole population (Dutton, 1997: 14), a belief crystallised in the Social Insurance and Allied Services report (Beveridge, 1942).

There was also a sense of duty among those in government to ensure that the new Britain would be one worthy of the sacrifices made by soldiers and communities in war time and during the inter-war depression. Town and country planning was seen as important to its delivery. Indeed, the President of the Board of Trade, Labour MP Hugh Dalton, described the emerging Distribution of Industry Act 1945 to the House of Commons as "the first instalment of a debt of honour which we owe to some of the best and bravest of our fighting men... and to those...communities of gallant people who, in the inter-war years, suffered mass unemployment, cruel frustration and deep poverty through no fault of their own" (HC Deb 21 March 1945, c821).

The very real effects of bombing also created spaces in which the town planning idea could flourish; bomb damage has been argued by Ashworth to be the "greatest stimulus brought by war to town planning" (Ashworth, 1954: 227). In the House of Commons debate over the second reading of the Distribution of Industry Bill in 1945, Norman Bower MP remarked: "One of the few things for which we have to be grateful to Hitler and the Germans is that they have given us the opportunity of replanning our towns and cities and redistributing our industry on a scale which we should probably never have contemplated had it not been for the destruction caused by enemy action" (HC Deb 21 March 1945, c911).

By the end of the war there was a cross-party consensus that "the main planning objectives...[of] planned urban containment with the dispersal of population to New Towns - were accepted as absolutely necessary" (McKay \& Cox, 1979: 30-31). Such was the context for the institutionalisation of town and country planning in England during and in the immediate aftermath of the war. We now turn our attention to the specifics of how the ideology of the institution of town and country planning was articulated. At the core of this institution lay the concepts of town, country, society, liberty, state, and property. 


\subsection{Town, Country and Society as Core Conceptual Stabilisers}

We have seen how, by the 1940s at least, the principle of town and country planning had gained general (although not unanimous) support across the political spectrum. This was on the basis of a shared assumption that it was an acceptable means to accepted ends. The Uthwatt report assumed that these ends were to ensure that "the best use is made of land with a view to securing economic efficiency for the community and well-being for the individual" (Uthwatt, 1942: 11). To this, we can add the protection of rural areas from "towns spread out and sprawled over the countryside in ways that have been both terribly wasteful of agricultural land and also inimical to the development of any real community life in the suburban fringes themselves" (Scott, 1942: 21). It is therefore the relationship between town and country coupled with the concept of society which provided the conceptual stability within which debates about the more hotly contested (and also core) elements of the nascent institution of town and country planning took place.

Given its terms of reference, the Scott report offers a helpful insight into the nascent institution of English town and country planning's conception of the relationship between town and country. Stevenson (2005: 207) argues that the Scott report "reaffirmed the pastoral image of Britain". Its opening passages evoke the spirit of 'deep England' in its claim that: "We are united in sharing a deep love for our countryside" (Scott, 1942: v), and its subsequent quotation from HG Wells' The History of Mr Polly (1910), with its evocation of a rural idyll shaped by "firm yet gentle lines of hill and dale...[and the] ordered confusion of features...[of] mother England" (as quoted in Scott, 1942: v).

The countryside which is the topic of the report is "a countryside which serves as a home as well as a workplace; a countryside which gives inspiration and delight; the heritage of the English-speaking world" (Scott, 1942: 14). There was thus a degree of Romanticism about the countryside evident in the Scott report, along with a spirit of nationhood and history. This could appeal to the war-time patriotism of individuals across the political parties. In the words of Stevenson, "in common with other spheres of public policy, the countryside had become a part of consensus which spanned the political spectrum" (Stevenson, 2005: 210).

There was a parallel anxiety about the countryside's relationship with the town. The Barlow report anguished that: "We...have despoiled the countryside" (Barlow, 1940: 226), and that the urban sprawl which has been allowed to develop "without the emergence of anything which could be described as a town with town advantages...constitutes indeed the most insidious menace to the countryside which exists today" (Barlow, 1940: 226). Parliamentary debates of the time exhibit similar language, with references to "the 
horror of snakelike tendrils reaching miles out beyond London" (Andrew MacLaren MP, HC Deb 11 May 1943, c537).

The concepts of town and country were not just associated with the protection of the rural idyll and spirit of Englishness, but the welfare of urban and rural communities too. Indeed, the Scott report was keen to emphasise that: "we do not want a countryside which behind a smiling face hides much human poverty and misery: and it is for that reason we have given close study to the material needs of the rural population in considering "the well-being of rural communities"” (Scott, 1942: v). The Barlow report also situated its discussion in the context of the welfare of the communities living in rural and urban areas which had suffered the ill-effects of the 'drift from the land', and expresses concern that "the activities of the speculative builder and the costly flat and fringe re-housing policy of the Government may, unless controlled and modified, inaugurate a new era of social maladjustment" (Barlow, 1940: 226).

For the Barlow Commission, therefore, the issue was not simply one of strategical and economic risks associated with agglomeration of industry, but also the social impacts. There was a corresponding underlying acceptance that the most appropriate way in which to ensure that the harmful effects of industrial agglomeration and urban sprawl had on the welfare of communities and the countryside were controlled and mitigated (or even removed) was through state intervention in property rights and use of land. Indeed, it is stated at the outset of the Uthwatt report that the committee has made the assumption that "national planning is intended to be a reality and a permanent feature of the administration of the internal affairs of this country... and that it will be recognised that this involves the subordination to the public good of the personal interests and wishes of the landowners" (Uthwatt, 1942: 11).

An acceptance of such principles, coupled with the acceptance that the beauty and productivity of the countryside should be safeguarded provided a degree of conceptual stability which thereby enabled other core contested concepts of liberty, state and property to be sufficiently decontested in the institution of town and country planning. Such an argument is accepted in the Uthwatt report, which was penned not by utopian socialists or communal anarchists, but by valuers, surveyors and property experts, who argued that "the more complex the productive organisation of society, the more highly developed must be the control of land utilisation exercised by or on behalf of the community" (Uthwatt, 1942: 11). It was for these reasons that in his 1951 analysis of the contemporary English planning system, Harvard University land law and planning expert Charles M Haar describes the 1947 Act as representing "a daring experiment in social control of the environment. The national decision of the British people has become crystallized: all future land use and development is to be guided along communally predetermined channels" (Haar, 1951: 1). 


\subsection{Liberty, Property and the State}

In the early town and country planning movement there was a tension between the concepts of liberty of the individual and the liberty of the wider community and society as a whole. This was exemplified by Howard and Geddes. For them, individual freedom was a function of the individual's membership of a community. But for them, this community would be self-governed and to a large extent free from interference by a centralised state. This conception of liberty was very much altered in the process of the institutionalisation of town and country planning in the 1940s.

The New Liberal debate on liberty coupled with Fabian socialist ideals tells us that the liberty of the individual to determine their own fate is impinged upon by a lack of social and economic power. Thus, the plight of the disadvantaged urban or rural dweller was one of relative lack, or inequality in the distribution of freedom to self develop. This is contrasted with the liberty of the individual (or class of individuals) which enjoys a greater degree of social and economic power, such as landowners or industrialists.

To interfere with an individual's property rights is therefore to impinge upon their liberty. However, the 1947 town and country planning system sought to reconcile this tension by proposing a degree of interference by the state in the individual liberty of property owners and private industrialists in order to enhance the degree of positive liberty enjoyed by society as a whole, and the more disadvantaged members of it in particular. Through national planning control, therefore, the state could broaden the distribution of positive liberty throughout society at the cost of the negative liberty of industrialists and landowners, thus "settling the balance between the individual and social rights in privately owned land" (Haar, 1951: 10). We see here a conception of the state as being closely equated with the concept of society in terms of it acting in the interests of the collective at the expense of some freedoms of some individuals. In this sense, the linked concepts of society and the state temper the potential excesses of liberty and directs it to conceptions of the common good.

Crucially, however, the emerging modern institution of English town and country planning was not only about the relative liberty of individual landowners and the community. It was also about the liberty of private industry and the liberty of the communities affected by its decisions. It is in this area that we see an emergent attempt through planning to reconcile social and economic objectives, and through this, an association of the concept of the economy in the institution of English town and country planning, with concepts of liberty and society and through these, the state. This tension in the relationship between these 
concepts would become ever more manifest over the next few decades, eventually reaching crisis after 1979.

At the time of the Uthwatt report, however, town and country planning was not understood as unduly inhibiting economic growth, nor as acting to positively intervene and direct it. Instead, planning was understood as acting to "prevent the work of reconstruction [after the war] being prejudiced" (Uthwatt, 1942: ii). For the authors of the Uthwatt report "the economic and physical aspects [of post-war recovery] are closely related" and they saw it as their "duty to ensure that [their] recommendations provide a suitable basis for whatever policy may be adopted so that it may be freed from any elements which might 'hamper, prejudice or delay' its effective execution" (Uthwatt, 1942: 7). The concept of the economy was therefore of importance to the institution at this time, and indeed it helped legitimise the creation of the institution as planning was framed as being necessary for efficient economic growth. However, the imperatives for reconstruction, economic growth and protecting the productive capacity of the countryside were not emphasised at the expense of other objectives.

Throughout the Barlow report, for example, there is an examined tension between the freedom of private commercial interests, and the welfare of communities affected by industrial agglomeration and unemployment. It asks: "Are these vast concentrations a necessary feature of our commercial and our industrial life from the point of view of economic prosperity? If so, must they continue to be a menace to the health and wellbeing of the people?" (Barlow, 1940: 8). The report concluded that the state should intervene in the freedom of industrialists in order to carry out planned decentralisation in the national interest, and suggested the acquisition "by compulsory purchase...the development rights of all undeveloped land in the country" (Barlow, 1940: 117). It would be this latter suggestion which would be further explored through the Uthwatt report and later carried forward in the Town and Country Planning Act 1947, thus forming a central component of the institution of English town and country planning.

The nationalisation of development rights seemed to offer a practical solution to the ongoing political fracas over nationalisation of the ownership of land, a measure which was rejected in the Uthwatt report "on the grounds of political unacceptability" (Cullingworth, 1975a: 257). Although 'the land question' had become a less vexed one since the Edwardian era, it was in the 1940s still politically divisive, and the "issue of urban land reform directly contributed to the eventual decision of the Labour Party to leave the [war-time] coalition", with large sections of the Labour Party still wishing for full land nationalisation (Tichelar, 2003: 167). 
However, despite Labour's 1945 election manifesto pledging to work towards land nationalisation, this option was later rejected by the Labour Party in line with the recommendations of the Uthwatt report and the Coalition government's white paper The Control of Land Use (MTCP \& SSS, 1944), which had officially confirmed the government's intention to introduce a national system of land use planning based on the state acquisition of development rights (rather than full land nationalisation). For McKay \& Cox (1979: 79 - emphasis in original), this was because of "the electorate's antagonism to outright nationalisation, with its implied attack on the rights of the individual to own housing" and the Labour Party therefore shied away from an issue with "potentially high political and economic costs, but of relatively low political salience".

Reade (1987: 51) argues that the Town and Country Planning Association ("TCPA") which had been instrumental in promoting the planning project over the preceding decades had "in a classically Fabian way, cultivated and infiltrated the administrative elite" and, although there were some TCPA members who "saw the purpose of town planning as the equalization and collectivization of living conditions, as in the Soviet Union", had "carefully distanced itself from any overt political commitment", thus ensuring that land use planning was not necessarily connected to the concept of land nationalisation, and helping to secure support for planning from a range of political and administrative interests.

In the end, the 1947 Act nationalised development rights in all land so that no development could take place without express permission from the state, to be compensated for out of a $£ 300$ million fund in cases of hardship, and required that a variable development charge representing $100 \%$ betterment be paid to the state by the purchaser of land following the grant of planning consent. It was intended that the betterment charge would allow the state to collect the increase in land value resulting from the grant of planning permission, with the landowner receiving only the value of the land in its existing use. The 1947 town and country planning system therefore nationalised development values, as well as development rights.

As the Uthwatt report pointed out, the necessity for some kind of form of such provisions arose as a result of a tension between the nature of planning, and the system of land ownership in the economy of the time: "the compensation difficulty exists because planning, which is directed to securing the best social use of land, tried to operate within a system of land ownership under which there is attached to land a development value depending on the prospects of its profitable use" (Uthwatt, 1942: 22). Thus did the 1947 Act institutionalise "the affirmative claims of the community upon property rights to an extent never before seen in common law countries" and in doing so represented "a significant change in Western thought with 
respect to the balance struck between the individual's rights in land as against those of society" (Haar, 1951: 2).

However, despite the broad consensus across political parties on the need for further planning measures, it is important to acknowledge that there remained sometimes significant disagreement regarding the extent and precise operation of these measures, particularly regarding the financial provisions of the 1947 Act. Indeed, over 1,400 amendments were tabled during the passage of the 1947 Bill which were roughly equally split between the Labour government and the Opposition (Cullingworth, 1975a: 241).

Objections the Conservative Party made regarding the 1947 Bill included the amount available to compensate landowners for the acquisition of development rights (the $£ 300$ million fund was derided as an “absurdly small sum" by Lord Llewellin (HL Deb 4 June 1947, c147) and as "just a guess" by The Earl of Radnor (HL Deb 5 June 1947, c224) in the House of Lords second reading), the lack of clarity regarding how the development charge would be calculated and administered and whether it would discourage development, and the values to be used to calculate the level of compensation to landowners whose land was to be compulsorily acquired (the 1947 Bill initially sought to base compensation on 1939 values rather than current market value).

For some, including land-owning and Conservative Party supporting members of the House of Lords, the financial provisions of the 1947 Bill were an unjust imposition, and the proposed operation of the wider measures represented an unwelcome expansion of state power and associated red tape. Lord Llewelyn, for example, accepted that "there was far too much laissez faire" in the 19th century, but "in one or two respects the present Bill goes much too far in the other direction" (HL Deb 4 June 1947, c140). The 1947 Bill was opposed by the former Conservative Minister for Town and Country Planning in the later war years, William Morrison, due to the lack of clarity regarding the precise operation of the financial provisions, including the issue of precisely how much an individual landowner could expect to be paid in compensation of the loss of development rights, leading Morrison to conclude:

"I fear that the uncertainties and injustices to which I have referred will hinder development and postpone the delivery of the homes which are so badly needed. No true friend of town and country planning would desire such a result - such a conflict between planning, on the one hand, and the provision of homes, on the other. It must give rise to irritation with all planning, and render more unacceptable the object to which all good planning is directed."

(HC Deb 29 January 1947, c1000) 
However, these objections were principally to technical questions, including those relating to the principles of the operation of the compensation and betterment provisions of the 1947 Bill; debate surrounding these issues was not focused on the underlying principles of planning, but rather on policy design. The representatives of the landowning class in the House of Lords did not therefore object to the principle of the 1947 Bill; their objections were focused on how landowners would be compensated for the shift in relationship between property, liberty and the state which the financial provisions represented. This view was expressed by The Marquess of Salisbury in the House of Lords second reading of the 1947 Bill. He questioned whether there should be a development charge at all (perhaps because the introduction of the charge would reduce the amount that landowners would receive when selling development land), while also stating:

"We have seen ribbon development stretch out its tentacles over the countryside; we have seen the deplorable result of unrestricted development and re-development in our great cities, and I am certain that there is a general consensus of opinion that something must be done. If that involves limitations on the liberties and action previously enjoyed by certain sections of the population, I think we are all ready to accept that fact. That is not only the view of Socialists, or bureaucrats, but of a great proportion of the landlord class, who are not always, perhaps, quite so black [sic] as they are painted."

(HL Deb 5 June 1947, c261)

In the end, the only major issue on which the government conceded was the 1939 basis for compensation, which was eventually changed so that compensation would be based on current market value, a change which was "generally welcomed" (Cullingworth, 1975a: 242). However, the shift to current market values did not result from a Lords amendment, but from a proposition by Hugh Dalton, who was at that time was the Chancellor of the Exchequer for the Labour government.

\subsection{The Plan, the Region and Debates Over the Scales of Planning and Governance}

The extension of the powers of the state and its interference in private property in order to secure a just redistribution of liberty, prompted questions about the concept of 'the plan' and therefore about governance 
and the relationship between central and local state authority. We see through the intersection of these concepts a nascent debate about regionalism and localism.

The Barlow Commission in its majority report had recommended that a "'Central Authority', national in scope and character" (Barlow, 1940: 201) be created in order to oversee the decentralisation and dispersal of industry nationally, and recommended that municipalities should be encouraged to deal with the problem "so far as found desirable, on a regional rather than on a municipal basis" (Barlow, 1940: 202). Although the minority report of the Barlow Commission recommended that such a central authority should have statutory regulatory powers nationwide, rather than just around London, there was a common acceptance of the need for a central guiding authority and for the potential desirability of planning authorities working in a more joined-up and cooperative fashion to develop a plan.

We thus see the growth and development of the concept of the plan from that of a series of piecemeal and disconnected local regulatory 'planning schemes' administered by local authorities "which would be nothing more than...a patchwork of schemes of varying size, and varying merits, which had not been coordinated and moulded into a coherent whole" (Barlow, 1940: 106), to a more comprehensive and positive conception of the plan as something which could help deliver national objectives. This pointed towards some form of national planning institution. However, a greater degree of central direction in town and country planning would have consequences for the operation of the concept of the state and the relationship between different parts of it: "The local and national interests may easily clash" (Barlow, 1940: 106).

Practical steps were taken in the Town and Country Planning (Interim Development) Act 1943 to broaden the concept of the plan: it made the production of planning schemes under the provisions of the 1932 Act compulsory for all local authorities, thereby bringing the whole country under potential planning control. The number of planning authorities was reduced from 1,441 to 145 under the 1947 Act (Cullingworth, 1988) following recommendations from the Scott Committee that "the primary local planning unit should be the county, or county borough and its surrounding area, or a combination of local government units comparable in area, resources or importance with a county"; such consolidation of planning powers was considered necessary as, without it, "coordinated planning over wide areas cannot be adequately achieved" (Lewis Silkin MP, HC Deb 29 January 1947, c958). These county planning authorities would be responsible for plan-making, while regulations were made "authorizing delegation of the power to grant planning permission to councils of county districts in the area of the local planning authority" (Haar, 1951: 50). 
This reduction in the number of planning authorities under the auspices of a centralised state power was not without its objectors. Sir William Darling, Unionist Member of Parliament for the Edinburgh South Constituency, professed himself in the House of Commons Debate on the 1947 Bill to be "an independent opponent of all large-scale, centralised, bureaucratic planning", and that he believed in "the decentralisation of these powers, and that the nearer we are to the people...the more we get a response from the people as to what the people want" (HC Deb 30 January 1947, c1194). For him, "coordination and centralised control" by the Minister was "a profoundly dangerous idea and the very negation of democracy as it removes people from the direction of their own affairs to centralised direction from Whitehall or some other place equally disreputable [the House of Lords]" (HC Deb 30 January 1947, c1194).

He was joined by Conservative MP Sir Mervyn Wheatley who gave the opinion that "it is very irritating to be a member of a big non-county borough and feel that you are not allowed to plan your own town, that it must be handed over to somebody who is remote" (HC Deb 30 January 1947, cc1167-1168). Labour MP Fred Marshall similarly sympathised with "the district councils and the non-county boroughs, whose planning powers will be given to the county councils" but went on to claim that "planning in larger units is essential, if we are to plan this country aright" (HC Deb 30 January 1947, c1146). Labour MP Thomas Braddock had similar reservations about the governance implications of a nationally-led planning system: "This matter of town and country planning can be developed admirably by the smaller local authorities. They are the people who can do it best. Let us have the national plan. Let us have the regional outline plan, but do not let us impose on the lesser authorities these regional bodies, with their staffs and professional men. Let these people have freedom..." (HC Deb 30 January 1947, c1156).

These debates regarding the redistribution of planning powers away from local districts and into counties signify a critical engagement with the nascent concept of the region as arising from the tension between a national institution of planning, the strategic dimension in such an ambitious vision, and its manifestation at the local level. This exhibits a tension at the heart of the nascent institution of national English town and country planning, between the perceived necessity of the expansion of central state power through the concept of the plan in order to promote greater liberty and justice through planning, and the consequent impingement on the freedom of self-determination at the local level of government.

\subsection{Summary}

The preceding section has sought to demonstrate that the ideology of the institution of English planning in the late 1930s and 1940s was assembled around a range of essentially contested concepts, the partial but sufficient decontestations of which in the context of the wider post-war settlement created a stability which 
supported certain policy programmes and policy ideas. Acting as a core conceptual stabiliser was the idea that the relationship between town and country should be managed and controlled in order to both protect the beauty, amenities and productive power of the countryside (and its 'Englishness'), as well as the quality of life in rural and urban areas.

These concepts of town and country allowed the potential dynamism of other core concepts of liberty, property, the state to be contained and controlled. The ideology of the institution of English town and country planning in 1947 accepted that although any interference in private landed property was an interference in individual liberty, it was necessary and indeed desirable for this to occur if the result was a broader redistribution of liberty throughout wider society. Similarly, such interference in the freedom of private industry to carry out its operations where it pleased was also desirable, if it resulted in a reduction in harmful impacts of industrial agglomeration. Although the need to protect the economy from 'unnecessary' state interference through planning was recognised in the Uthwatt report, planning was generally framed as being necessary for the efficient economic recovery of Britain after the war.

The interaction of these concepts in the ideology of the institution of English town and country planning in the 1940s necessarily incorporated the concept of the state. There was an acceptance that it would be through state power that such interventions aimed at redistributing liberty more widely through society would be delivered, with private enterprise its subject. This intervention would be carried out through planning. However, there was disagreement over the appropriate scale of planning, with some calling for a national plan, and some calling for a complete devolution of planning powers to local authorities, thus reflecting debates about the scalar distribution of liberty through the state itself. In the end, a sort of settlement was reached in which planning powers would be consolidated among the 145 counties and county boroughs who could choose or be compelled by the Secretary of State to agglomerate into regional planning areas.

There are particular areas of tension in the articulation of these concepts. One significant area of tension is that which arises between the articulation of liberty, state and property. The ideology of the institution of English town and country planning at this time held that the expansion of state power through the plan and the consequent interference in private property would enhance the distribution of liberty and power. But this concealed latent ideological contestation which was to become increasingly manifest over the next few decades, reaching crisis point in the 1980s. Similarly, the relationship between the state, liberty and the plan produced conceptual tensions. The ideology of the 1947 system (as enacted) accepted the principle of a strong, centralised state empowerment of statutory plan-making as administered by a network of counties 
and county boroughs. But this concealed latent tensions over benefits that would be offered by a more explicitly regional, or even national, approach to plan making, as opposed to the benefits of allowing local authorities to set their own objectives and plan accordingly. It would be the concept of the region which, as will be shown, would later become a focus for deep contestation. 


\section{The Neoliberalisation of Planning}

We saw in the previous section that a key factor enabling the formal institutionalisation of English town and country planning was the so-called 'post-war consensus' regarding the need for state intervention in the economy in the interest of the welfare of society. The 1947 Act and, indeed, the principle of the 1947 system of English town and country planning as a whole, can therefore be seen partly as a manifestation of this broader social democratic settlement, as an attempt to steer a 'middle way' between extreme forms of the concepts liberty (in which the individual is sovereign) and the state (in its extreme form as an analogue for society), by retaining a market in land but nationalising development rights so that the power to grant permission to develop was vested with the state (Taylor, 2009).

This settlement, as manifested in the principle of a town and country planning system, ostensibly remains in-tact today: the modern English system still rests on the foundations of the 1947 Act. However, as the remainder of this paper will demonstrate, this apparent continuity masks significant changes in the ideological structure of the institution, changes which are intimately linked with the fortunes of the postwar settlement and the ideological shifts in central government. Indeed, 40 years after the 1947 Act, the Nuffield Foundation's inquiry into the planning system reported: "The immediate post war consensus on planning objectives - the consensus on which the planning system was founded - has largely disappeared" (Nuffield Foundation, 1986: 29). The following section therefore foregrounds the morphological analysis of the ideology of the post-2010 Coalition period of planning in section 6 by briefly exploring how the Nuffield Foundation felt it could come to such a conclusion, with a special emphasis on the New Right period in British politics.

\subsection{The Post War Consensus and the End of Ideology}

The period between 1945 and the mid 1970s in Britain is commonly described as being delimited by "an arrived-at unstated accommodation between parties on the various foundations of policy" (Heffernan, 2000: 149), and that these foundations were piled into an "ideological bedrock" (Thompson, 2004: 50) of Keynesian demand management and state intervention in the economy, which allowed for the relegation into the background of "disputes between planners and anti-planners, businessmen and socialists" (Skidelsky, 1996: 49). While not the precise target of their critique, it was this kind of settlement that was the focus of the 'end of ideology' literature of the 1950s and 1960s (Aron, [1957] 1968; Bell, [1960] 2000; Lipset, 1960; Shils, 1955, 1958). A well known example is Daniel Bell's The End of Ideology - The Exhaustion of Political Ideas in the Fifties (1960) in which he argued that the 'age of ideologies' was over 
in the West because the main ideological families, socialism in particular, had lost their intellectual force and power to inspire broad social and political movements.

Bell argued that people no longer believed in the complete models of society which these ideologies seemed to offer, and that politics in the West had become managerial, pragmatic and technocratic. Bell and others could argue this because it seemed that the extremes of ideological debate which had comprised the battlegrounds of political ideas in the west throughout the 19th and early 20th centuries were over, replaced with a narrower field of contestation around a broadly liberal, social democratic common ground of which the post-war settlement in Britain was a classic example. Bell argued that this "normative consensus" which was consolidated in the post war years in the West "held that civil politics could replace ideological politics; that the dream of organizing a society by complete blueprint was bound to fail" and that contemporary politics was prudently conducted from within the limits imposed by a "framework of liberal values" (Bell, 1988: 138 - emphasis in original).

While the 'end of ideology' thesis seemed to relegate ideology to history, this argument depended on a rigid conception of ideology which frames it in classical terms, as a closed and clearly demarcated "all-inclusive system of comprehensive reality" which "seeks to transform the whole way of life" as a kind of "secular religion" (Bell, [1960] 2000: 400). In the context of the political pluralism and policy consensus of the 1950s in comparison with the more wide-ranging ideological debates of earlier in the 19th and 20th centuries, this critique held some power. Yet it breaks down in the face of a more nuanced understanding of political ideologies as being not fixed, clearly bounded phenomena, but plural, porous, subject to change, able move on to the ideological territory of rival systems depending on historical context, and able to support similar policy means and ends for different ideological reasons. The extremes of ideological debate in the West may have subsided in the post-war period, but contestation among and between political parties, intellectuals and the general populace nevertheless endured.

The policy consensus which existed in Britain in the post-war period should not therefore be seen as symptomatic of the 'end of ideology'. It should instead be seen as a period of broadly Keynesian policy continuity established in the aftermath of the second world war, which was partly a function of a narrower field of ideological contestation in comparison with earlier decades, as well as being a function of the desire among political elites and civil servants to ensure stable governments in a period of post-war rebuilding, so it would not be undermined by the effects of radical policy shifts. 
Hickson (2004) takes this view in an analysis in which he argues that the post-war consensus largely consisted of agreement on policy means which were justified from different and competing ideological positions regarding policy ends both across political parties and within political parties. He argues that there was no strong ideological consensus at the time, with the Labour Party, for example, split between statists and revisionists such as Anthony Crosland (1918 - 1977) ([1956] 2006) who argued for the old socialist objective of public ownership to be relegated to one policy option among many in the pursuit of social justice and equality. The Conservative Party, on the other hand, had no strong theory of equality, believing instead that inequality was necessary and desirable to the achievement of the 'good society', although the One Nation communitarian element believed that inequality should be kept to within reasonable limits.

Yet despite these ideological differences, the parties could agree on the broad programmatic direction of policy in the post-war period as they could be justified for reasons which were consistent with the demands of their respective ideological frameworks. This argument is put succinctly by Freeden: "A closer look at the debate of the 1950s will demonstrate that the welfare state served different ideological ends for the Conservative and Labour Parties: for the former, it reinforced ideas concerning social harmony, order, and prosperity; for the latter, it held out the prospect of social justice, equality, and community...Political consensus may thus be far removed from ideological convergence" (Freeden, 1990: 32). This political consensus was shored up by the fact that, despite their ideological differences, "both parties were prepared to co-operate in making the constitution work and ensuring reasonable stability and continuity of policy" (Gamble, 1984: 178).

The analysis of the nature of the post-war settlement as primarily comprising a pragmatic agreement of policy means which could be agreed upon from various ideological positions within and between the political parties in Britain mirrors the nature of the agreement over the institution of planning at this time. As with the broader consensus over economic policy, various ideological perspectives could 'read' in planning a compromise which they could support. Reade (1987) argues that the 'legitimation and consolidation of the planning system' in the post-war period was in part due to the 'holism' of the ideology of planning, which he describes as manifesting in "the tendency of the planning lobby both to wrap up all its prescriptive ideas into a single readily-comprehended 'package' and to assert a consensus of interest among all groups in society in pursuing that 'package' of policies" (Reade, 1987: 66). According to Glass (1959):

"Town planning was advocated as a device for getting the best of all worlds: individualism and socialism; town and country; past and future; preservation and change...This is an attractive 
doctrine: it presents so many different faces that it hardly seems to require scrutiny...This streak of ambivalence has certainly helped the British planning system in winning consent."

(as quoted in Thornley, 1991: 26)

However, despite the existence of a relatively stable policy and institutional context, as with the terms of the broader post-war settlement, the institution of English town and country planning did of course undergo change, particularly regarding the relationship between private property and the state. The Conservative Party abolished the $100 \%$ development charge through the provisions of the Town and Country Planning Act 1953 and from this point on, the financial provisions of the English planning system were in dispute. Cox (1984) provides an account of the institutional dynamism around the financial provisions of the 1947 system, and the degree to which the state was to be involved in the delivery of planned development (i.e. 'positive' vs. 'regulatory' planning). These fluctuations generally followed the pattern of changing governments: the Labour Party would introduce legislation and policy which allowed for higher degrees of state intervention in the private land market, and for higher degrees of state involvement in the delivery of plans (e.g. Land Commission Act 1967; Community Land Act 1975); the Conservative Party would repeal such legislation and introduce changes which scaled back state-intervention and allowed for a more unfettered operation of the private land market and private sector delivery of planned development (e.g. Land Commission (Dissolution) Act 1971; Local Government Planning and Land Act 1980).

What this illustrates is that in this area of the institution of planning which was so closely linked to contestations regarding the proper relationship between liberty, property and the state, there was a degree of institutional dynamism which seems to match the general ideological preferences of the Labour Party (towards more social democratic approaches based on the mixed economy) and the Conservative Party (towards more 'adversarial' policies and a private land market) in British post-war politics (Cox, 1984). So despite the broader stability in the policy framework in the post-war period, ideological contestation regarding the proper form of the institution of planning as it related to private land ownership and state-led development endured. However, the focus of this debate was contained so that at no point was the principle of a planning system and the alienation of development rights from land ownership rights as imposed by the 1947 Act significantly challenged. Despite some institutional dynamism, in this respect at least, there was consensus and continuity across the two main political parties in England regarding town and country planning (and the state intervention in land and property rights it represented) as an acceptable means in itself.

\subsection{The Rise of Neoliberalism and the Breakdown of Consensus}


The broader post-war consensus regarding Keynesian economic policy in Britain held until the 1970s. However, it was during this latter period, particularly following the election of Margaret Thatcher (1925 2013) as leader of the Conservative Party in 1975, that the "dominant economic understandings changed as the intellectual pendulum swung from left to right, from Keynesianism to neoliberalism" (Hay, 2001: 237). This would result in the breakdown of the post-war consensus and general policy continuity it represented (adversarial debates over the financial provisions of the planning system discussed in the previous section notwithstanding), and would eventually establish a new period of apparent consensus based on neoliberal principles of individual responsibility, reduced state intervention in the economy and the championing of enterprise and growth.

However, neoliberalism and its Thatcherite incarnation was not an ideology that emerged in the late 1970s. Indeed, Jessop argues that there exists a pre-history of Thatcherism in the period 1965-1979 which consisted of “failed efforts under [Edward] Heath's One Nation Conservative government and [Harold] Wilson's Labour Government to modernize Britain; the breakdown of the post-war settlement and the rise of new social movements; and the rise of the new right and little Englandism" (Jessop, 2015: 18-19).

There had in fact been dissenting voices in the 1940s even while the settlement was being negotiated. One well known dissenter was Friedrich von Hayek (1899 - 1992) who published The Road to Serfdom in 1944 in which he called for a return to 19th century classical liberal values in the face of what he perceived to be a turn to dangerous socialist ideas in wartime Britain. The book was popular enough for a Reader's Digest 'condensed version' to be published in the USA in April 1945, and Hayek's argument would in time prove influential on those who would later promote the ideals of neoliberalism in Britain and the USA. Indeed, Margaret Thatcher would remark of The Road to Serfdom: "It left a permanent mark on my own political character, making me a long-term optimist for free enterprise and liberty and sustaining me through the bleak years of socialist supremacy in the 1960s and '70s" (Thatcher, 1993: 13, as quoted in Beech, 2006: 159).

Hayek's argument is worth summarising because it neatly encapsulates the broad terrain of the later neoliberal critique of the post-war settlement and illustrates the terms of its contestation of the concepts of liberty, property and the state which were of such core importance to the institutionalisation of English town and country planning in the 1940 s.

Hayek was a committed liberal who argued for a return to 19th century classical liberalism. He had watched aghast "the evolution of ideas" in Austria and Germany which he thought gave rise to the authoritarianism 
of National Socialism and was alarmed at what he saw as a similar process happening in British intellectual and political life in the inter war and wartime periods (Hayek, [1944] 2006: 2). The Road to Serfdom is a critique of what he saw as the inevitable practical outcome of socialist theory, which would be a state of authoritarianism and un-freedom. This was in contrast to the revisionist New Liberal argument, detailed in section 3, that collectivism and state planning would help secure a broader distribution of liberty.

He therefore critiqued the "subtle change in meaning to which the word freedom was subjected in order that this argument should sound plausible" (Hayek, [1944] 2006: 26). The transformation of the meaning of liberty from "freedom from coercion" to "freedom from necessity, release from the compulsion of the circumstances which inevitably limit the range of choice of all of us" and the promise of 'more freedom' it represented, was for Hayek "one of the most effective weapons of socialist propaganda" and "was responsible for luring more and more liberals along the socialist road, for blinding them to the conflict which exists between the basic principles of socialism and liberalism, and for often enabling socialists to usurp the very name of the old party of freedom" (Hayek, [1944] 2006: 26-27).

This argument extended to a devastating critique of planning, by which Hayek meant "the planning which is to be substituted for competition" (Hayek, [1944] 2006: 44) (and not specifically town and country planning). A crucial part of Hayek's argument is his view of the amorality of the market versus the morality of planning. By this he meant that planning, by virtue of being a product of human agency and values, brings with it a moral vision for society which is imposed on the populace. This is in contrast to the amorality of the capitalist market which comprises "forces which we neither understand nor can recognise as the conscious decisions of an intelligent being" (Hayek, [1944] 2006: 210). Hayek argues that the refusal to yield to such forces is "the product of an incomplete and therefore erroneous rationalism" which fails to recognise that a planned approach would require "submission to an equally uncontrollable and therefore arbitrary power of other men" (Hayek, [1944] 2006: 210).

This affronted his liberal belief in the rule of law, which he accepted produces economic inequality, yet also defended because "this inequality is not designed to affect particular people in a particular way" (Hayek, [1944] 2006: 82). Therefore, for Hayek, any inequalities arising from the exercise of arbitrary human power over the economy is morally worse than any inequalities arising from the impersonal forces of the market. For Hayek, socialist and revisionist liberal concepts of social justice and equality were anathema. Inequalities arising from the unfettered operation of impersonal economic forces were considered morally preferable to those arising from planning. 
Of course, Hayek accepted the need for the state; it is necessary to protect life, liberty and property and to enforce the legal structures required to help ensure predictable behaviour in the market. So the debate was not about whether or not there should be government intervention in the economy and personal freedoms, but what form the necessary intervention should take and to what ends. The answer for Hayek was to return to the ideals, but not the reality, of classical liberalism: "The guiding principle, that a policy of freedom for the individual is the only truly progressive policy, remains as true to-day as it was in the nineteenth century" (Hayek, [1944] 2006: 246).

Neoliberal ideas gained currency in Britain over the post-war period while the post-war settlement was in place. Although it became clear that the oppressive socialist totalitarianism which Hayek so feared would not materialise in post-war settlement Britain, the country's worsening economic performance seemed to suggest that Keynesian demand management might not be the panacea it seemed. It was therefore during the economically tumultuous 1970s during which there was an energy crisis, a financial crash, rising inflation, and miners' strikes, that the post-war settlement in Britain came under severe strain. It came to be seen that the settlement had not delivered promised economic success and had failed to adjust theory to the reality of inflation (Skidelsky, 1996).

The cross-party consensus on policy means for different ideological reasons was therefore challenged as the policies ceased to meet desired ends. Leach, Coxall and Robins (2011: 122) argue that Thatcherism can therefore be seen as "the consequence rather than the cause of the breakdown of Keynesianism and the post-war consensus". The moment had come for monetarist and neoliberal ideas, and Margaret Thatcher duly started to promote a monetarist doctrine following her assumption of the Conservative leadership in 1975 and following her election as Prime Minister in 1979.

Thatcher's foreword to the Conservative Party's 1979 election manifesto stated: "No one who has lived in this country during the last five years can fail to be aware of how the balance of our society has been increasingly tilted in favour of the State at the expense of individual freedom" (Conservative Party, 1979). Elsewhere the manifesto criticised Labour for "practising the politics of envy and... actively discouraging the creation of wealth", having "crippled the enterprise and effort on which a prosperous country with improving social services depends", and "heaping privilege without responsibility on the trade unions" (Conservative Party, 1979).

The proposed solution as set out in the manifesto would be to control inflation, incentivise 'hard work', “uphold Parliament and the rule of law", support 'family life' (including encouraging home-ownership so 
as to create a property-owning democracy), and to "strengthen Britain's defences and work with our allies to protect our interests in an increasingly threatening world" (Conservative Party, 1979). We see here a blend of liberal and conservative ideas which emphasise the value of individual freedom over the collectivist state, and the importance of conserving and protecting traditional institutions such as family, private property and the nation state. It is for these reasons that the New Right in Britain has been conceptualised as being an uneasy combination of neoliberalism and neoconservatism (e.g. Harvey, 2005). It was therefore simultaneously new and a revival of different aspects of older traditions.

However, the implications of the neoliberal current in New Right thinking were not universally supported by members of the Conservative Party. There remained factions who were appalled by what they saw as a rejection by the New Right of One Nation conservative ideals (Barry, 2005: 46). These were the so-called 'wets' in the Conservative Party at the time, who opposed the neoliberal policies of the Thatcherite 'drys'. True to tradition, such Conservatives were concerned at both the plight of the less fortunate in One Nation terms, and at the destabilising effects of the neoliberal form of liberty on the organic society. For these traditional Conservatives, "individualism is dangerous if it means the elevation of social irresponsibility; desirable only when the individual is bound into social structures where his or her activities are reined in as concrete and particular instances of moral and conventional conduct" (Freeden, 1998: 399). We see here the ongoing anxiety regarding the relationship between the concept of individual liberty and society.

Thatcher's (and the New Right's) impact "stemmed from the fact she presided over a change of attitudes: individualist rather than collectivist, private rather than state ownership" (Cherry, 1996: 193). As Thatcher herself put it: "If you change the approach you really are after the heart and soul of the nation. Economics are the method; the object is to change the heart and soul" (as quoted in Butt, 1981). And change the heart and soul she did. ${ }^{4}$

\subsection{New Labour and the New Consensus}

The Labour Party's response to Margaret Thatcher's election as Prime Minister in 1979 was to seek to further differentiate itself from the Conservative Party by outlining in its 1983 manifesto a "programme of socialist reconstruction" based on partnership with local authorities and trade unions, which would see 'public assets' which had been "hived off by the Tories" returned to public ownership (Labour Party, 1983).

\footnotetext{
${ }^{4}$ For an analysis of the impact of the New Right on the English planning system, see Allmendinger \& Thomas, 1998; Thornley,
} 1993. 
The result was the worst electoral defeat since 1931. It seemed that times had moved beyond such seemingly antiquated ideas. The Labour Party would therefore have to respond by 'modernising', and altering its "programmatic stance, electoral strategy and stated political objectives" (Heffernan, 2000: 20) - it would have to respond by changing its heart and soul.

The Labour Party lost the 1987 and 1992 elections and, following the untimely death of party leader John Smith in 1994, Tony Blair was elected as new leader of the opposition and the New Labour project was put into action. Blair, who Dutton (1997: 151) has described as having "done more than any other Labour figure to enshrine the new political consensus of the 1990s", sought to reframe the aims and values of the party, and in 1995 successfully revised the wording of Clause IV of the Labour Party's constitution. The new Clause IV removed the party's long-standing commitment to the "common ownership of the means of production" and replaced it with an emphasis on the "strength of common endeavour" to create a community in which "power, wealth and opportunity are in the hands of the many, not the few" (Labour Party, 2014: 3).

Freed from the constraints of Old Left ideology, the Labour Party could now adjust its political project to reflect the new post-Thatcher political and economic context. Indeed, Heffernan (2000: 164) argues that New Labour was "a reflection of the ideological, political, economic, and, as significantly, electoral environment" in which the Labour Party found itself. In short, this position reflected the establishment of a new consensus around a new neoliberalised centre ground which had shifted following the electoral successes of the New Right and the rise of globalisation.

The Third Way was based on "uniting the two great streams of left-of-centre thought - democratic socialism and liberalism" (Blair, 1998: 1). This involved rediscovering the concept of liberty which had long been valued by socialists (thanks to socialism's engagement with the New Liberals in the early part of the 20th century). However, the form of liberty valued by New Labour would be "the primacy of individual liberty in the market economy" (Blair, 1998: 1). This concept would be promoted alongside that of social justice, but this would not be secured purely through state power, which would be relegated to be just one of many means, and "emphatically not an end in itself" (Blair, 1998: 1). This point was made in a 1999 speech by Jack Straw to the University College London Constitution Unit: "The third way is not a tight ideology, but a broad philosophical approach - a thrust of ideas which synthesises liberal concepts of freedom, rights and liberty with concepts of equality and collective values" (Straw, 1999). The Third Way was an amalgam of social democratic and liberal ends, to be delivered through flexible means, means which had ostensibly been decoupled from a strong emphasis on state intervention and control. New Labour's project resulted in 
electoral success in 1997 and over the next 13 years the new neoliberalised social democratic centre ground was consolidated.

What this meant for planning was a continuation of elements of the agenda set by the previous Conservative governments, including the framing of the planning system as needing to function predictably and efficiently so as to promote greater economic development (DTLR, 2001, 2002). This was legitimised through New Labour's ideology by its enthusiastic adoption of neoliberal ideas (see Allmendinger, 2011). However, this apparent continuity from the New Right era was subverted in New Labour's thinking through the insertion of a social democratic concept of community, an adjusted concept of liberty, and a different understanding of the enabling state in planning terms. As Shepherd (2017) has argued elsewhere, the interaction of these concepts would find institutional expression through the adjacent concept of the region, the peripheral concept of the regional spatial strategy and the extension of central state power through statutory spatial planning these concepts represented.

In summary, according to the ideology of New Labour, the planning system should act to support the smooth operation of the market and growth of the economy which would serve to improve opportunities for communities to self-develop and thereby broaden the distribution of positive liberty. The state would ostensibly play an enabling role in helping this to happen. The concept of community (which was an updated and transformed manifestation of the old socialist conception of society) was called upon to legitimise this programme for planning. By emphasising this concept, New Labour could discursively differentiate itself from the 'uncaring' Conservative Party while legitimising its more neoliberal ambitions. Through the lens of the institution of planning, the concept of the community brought with it an apparent emphasis on the devolution of power from the central to the local state so that local communities could determine development objectives in a locally responsive way. However, in practice, this apparent localism would be controlled and directed by significant strategic state oversight which would be manifested in the adjacent concept of the region and the perimeter concept of the regional spatial strategy ("RSS").

Regional spatial strategies were introduced through the Planning and Compulsory Purchase Act 2004 ("2004 Act") and were therefore a statutory requirement - every local authority in every region in England had to come together to prepare one. They were presented as a form of devolution of power from the centre and in theory these new regional planning spaces would be filled from the 'bottom up' rather than from the 'top down'. However, regional plans had to be prepared taking account of the direction set by national planning guidance and were to be the means by which unwelcome centrally-set regional housing delivery targets were to be distributed across local areas. Regional plans were therefore seen by some as oppressive 
requirements of central government. This was a view taken by many Conservative shires, whose opinions were voiced by Conservative MP (and future Secretary of State for Communities and Local Government) Eric Pickles who saw RSSs as reducing the degree of freedom at county and local level by "dragging in a more remote regional authority, thereby breaking the link with decisions made by local people" (HC Deb 17 Dec 2002, c738). This is contrasted with New Labour thinking which legitimised them as a necessary expansion of state power into regional political and geographical space in order to provide sufficient strategic oversight to ensure that the benefits of economic growth and good planning would create a broader and more equal distribution of opportunity and, therefore, freedom. We can sense here echoes of similar parliamentary debates conducted during the initial institutionalisation of planning in the 1940s.

Although by no means the only significant change in the institution of English planning introduced during the New Labour years, it would be the statutory regional aspects of planning and associated regionallyimposed targets for the delivery of housing which would be the particular focus of contestation in the years up to and following the election of the Conservative-led Coalition government in 2010. As will be argued in the next section, this was partly due to the fact that the concepts of liberty, the state, society and community are important concepts in conservative ideology as well as New Labour's, but that they were decontested and articulated in different ways. This fundamentally changed the role of the concept of the region in the ideology of the institution of planning, and therefore in the policies associated with it. 


\section{The Ideological Renewal of the Conservative Party}

When David Cameron was elected as leader of the Conservative Party in 2005, the Labour Party was enjoying its third consecutive term in power. The Conservative Party had lost its way and Cameron was elected as a much-needed moderniser much like Blair was before him. Cameron therefore engaged in a project to ideologically reposition the Conservative Party so that it could mount a realistic challenge to Labour's electoral dominance. To do so, he drew upon the ideas of a number of key figures in and around the Party. These included David Willetts who developed the concept of 'Civic Conservatism' which was an attempt to "reconcile free markets (which deliver freedom and prosperity) with a recognition of the importance of community (which sustains our values)" (Willetts, 1992: 92); Oliver Letwin who developed the conservative concept of the 'Neighbourly Society' and who would go on to be a main architect of the Coalition agreement with the Liberal Democrats in 2010; and Philip Blond, a centre-right academic. In different ways, these figures were concerned with how a rearticulation of the concepts of liberty, society, community and the state within conservative ideology might be employed to update the Conservative Party and legitimise its programme for government. As will be shown in this section, this rearticulation of the ideology of the Parliamentary Conservative Party would have significant implications for the institution of planning.

\subsection{Community, Liberty and the Conservative Mind}

In 2002 David Willetts, a then-Conservative Party MP and senior party intellectual who had served in Margaret Thatcher's policy unit, gave a speech to the centre-right think tank Policy Exchange in which he described the following passage as expressing "the fear of many Conservatives today" (Willetts, 2002b):

"All fixed, fast, frozen relations, with their train of ancient and venerable prejudices and opinions, are swept away, all newformed ones become antiquated before they can ossify. All that is solid melts into air, all that is holy is profaned, and man is at last compelled to face with his sober senses his real conditions of life and his relations with his kind."

In order to understand how it came to be that a Conservative MP quoted The Manifesto of the Communist Party (Marx \& Engels, [1848] 1969) in sympathetic terms to a room full of centre-right policy experts, we need to recognise how this curious event fits into the broader context of a prolonged theoretical engagement within the party with the concept of liberty and its role in conservative ideology. 
The above passage in its original context is a critique of the dynamism of the 'bourgeois epoch' of 19th century international capitalism. However, re-contextualised in conservatism by David Willetts, it becomes a critique of the concept of absolute individual liberty and a description of the challenge posed by such liberty to the institutions, traditions and cultures valued by the conservative mind. As such, it can be seen as an engagement with the threat to conservatism which was posed by the theoretical implications of the New Right's insertion of the neoliberal conception of liberty (in both its economic and social dimensions) into Conservative Party ideology, and an acknowledgment that the fears of the 'wets' in the early New Right era may have been well-founded.

The perceived threat that the neoliberal conception of liberty posed to conservatism has been expounded in some detail by philosopher John Gray, under whom David Willetts studied while at the University of Oxford: "Market liberalism...fosters a privileging of choice and a cult of mobility that consort badly with the settled communities cherished by traditional conservatives" (Gray, 1997: 23). He therefore concluded that: "The hegemony, within conservative thought and practice, of neo-liberal ideology has had the effect of destroying conservatism as a viable political project of our time" (Gray, 1997: 3).

For Gray, the "excess of individualism" which neoliberal freedom brings with it therefore threatens to dissolve within communities the "the shared understandings - the myths, rituals and narratives - that confer meaning on the lives of its participants" (Gray, 1997: 39). A surfeit of social and liberal freedom poses a threat to those histories, traditions and identities which the conservative is supposed to want to conserve. The unsettling dynamism of neoliberal liberty also brings with it the loss of valuable local knowledge, which is rendered "obsolete or irrelevant to the operation of market processes that are themselves ever more disembodied" (Gray, 1997: 40). A conservative should mourn this loss, "because such knowledge is constitutive of our very identity, is a central value in any outlook that is truly conservative" (Gray, 1997: 39).

Philip Blond had similar reservations about the implications of liberalism. For Blond it was through the ideological "conversion to free market fundamentalism" (Blond, 2008: 84) that Thatcher destroyed local industrial economies and communities. This, combined with the new internationalism of global capital, "severed completely the notion of a 'national capital', loyal to locality, community and country" (Blond, 2008: 85). For Blond, this meant Britain became an 'economic monoculture', framed by a 'monopoly capitalism' blind to identity, tradition and local institutions, and which "benefits the already rich at the cost of the dispossession and expropriation of the poor" (Blond, 2008: 85 - 86). For Blond: "An economy so 
construed disregards all other relationships and in the end undermines productivity, innovation and indeed society itself" (Blond, 2008: 85).

Gray and Blond in different ways frame untrammeled market liberalism and social liberalism as a threat to One Nation conservative values and, in doing so, question the extent to which neoliberalism (with its attendant emphasis on personal freedom, choice, mobility and development) has been allowed to assume such central importance in conservative thought. It is to this critique which David Willetts responded with his 'Civic Conservatism' concept, and Philip Blond with his 'Red Toryism' concept which, in different ways, sought to recover the concepts of society and community for conservatism.

\subsection{Community, Liberty, Civic Conservatism, Red Toryism}

David Willetts started to develop his concept of Civic Conservatism in the early nineties as a means by which to seek to reconcile the tension between the neoliberal concept of liberty, and traditional conservative concerns. Willetts was eager not to jettison the liberal element which provided the modern imperative for free markets, individualism and economic growth in Conservative thought. These in any case formed part of the post-Thatcher consensus and were here to stay. However, at the same time as lauding liberty and the free markets for delivering prosperity, enterprise and freedom, Willetts critiqued the strong neoliberal conception of them: “[A] conservative realises that...economic liberalism is 'very nearly true'. The trouble with the neo-liberals is that they simply think in terms of the individual economic agent without any understanding of the institutions, values and ties which are not just good in themselves but are anyway essential for any real free market to thrive" (Willetts, 1997a: 97).

Willetts is here engaging with the "creative tension between...our belief in individual freedom, private property and the market economy on one hand, and on the other a commitment to maintaining the institutions which hold our nation together" (Willetts, 1997b: 169). Willetts therefore retained the concept of liberty as central to conservative thought, while recognising that it needed to be anchored somehow, so that its destabilising influence could be controlled. It was the concept of community and, through it, society which would perform this function. For Willetts, the party needed a "Conservatism not just of economic and personal freedoms but also of social reform to create a stronger society. What it understands is that freedom is not enough on its own" (Willetts, 2005b).

There is overlap here with Philip Blond's Red Tory concept which similarly sought to reconcile the tension between liberalism and conservatism. According to Blond, the solution must be "grounded in a conservatism with deeper roots than 1979, and whose branches extend into the tradition of communitarian 
civic conservatism" (Blond, 2009). Blond thus invoked the spirit of conservative thinker Edmund Burke (1729 - 1797) and his "little platoons of family and civic association" (Blond, 2009) in order to argue for a radical form of conservatism which acknowledges the value of local communities and institutions in combination with a suspicion of the remote and totalitarian 'monopoly capitalism' which is the result of an unconstrained and international market liberalism. For Blond, the solution must be to develop an economy which recognises that: "A disengaged capital has no loyalty to Britain, its people, its history or its future" (Blond, 2008: 89). Conservatives must therefore "recover the notion of 'patriotic capital' - a resource dedicated to a renewed Britain of real investment and widely distributed property" (Blond, 2008: 89).

Willetts and Blond therefore sought to position the concept of community as a stabilising force adjacent to a neoliberal form of liberty. In doing so, they sought to refocus from the atomised individual economic agent "floating freely, untrammelled by ties, culture or history" (Willetts, 1997a: 82), to the agent as a node within a community network comprising individuals bound together through valued national and local institutions. Civic Conservatism and Red Toryism were therefore partly an attempt to acknowledge that: "For a Conservative just to celebrate the freedom of the individual would be missing something equally important. There is not just "me"; there is also "we"." (Willetts, 2005a).

\subsection{Neighbourhood, the State, Liberty and Responsibility: The Neighbourly Society}

By acknowledging the importance of the concepts of community and society, Willetts and Blond were engaging at some level with the interview given by Margaret Thatcher to Woman's Own magazine published on 31 October 1987, from which the most quoted passage is: 'there is no such thing as society'. Oliver Letwin specifically referenced this interview in a speech he gave at the Adam Smith Institute in 2002. In this speech, he quotes the entire passage from which the notorious 'society' quote is taken:

"We've been through a period where too many people have been given to understand that if they have a problem, it's the government's job to cope with it. 'I have a problem, I'll get a grant'. 'I'm homeless, the government must house me.' They're casting their problems on society. And you know, there's no such thing as society. There are individual men and women, there are families. And no government can do anything except through people, and people must look after themselves first. It's our duty to look after ourselves and then, also, to look after our neighbours. People have got their entitlements too much in mind, without the obligations."

(as quoted in Letwin, 2002) 
Letwin in his speech goes on to describe these remarks as an attack on "the Left's constant and unthinking call for 'society' to rush in and solve every ill" (Letwin, 2002). For Letwin, Thatcher was not therefore attacking the concept of society itself, but was attacking the concept of society as decontested by the Left; Letwin therefore rhetorically states: "when the Left say 'society' - then and still today - they inevitably mean the state" (Letwin, 2002). This would be later explicitly referenced in the Conservative Party's document Built to Last: the Aims and Values of the Conservative Party, which states: "We believe that there is such a thing as society, but it is not the same thing as the state" (Conservative Party, 2006: 1).

Instead of the state solving people's problems, responsibility (and therefore empowerment) must fall to "a society composed of active citizens, strong families and of neighbours who look out for each other" (Letwin, 2002). In short, a society comprising strong local communities. Like Willetts and Blond, Letwin was calling for conservatives to 'rediscover' the concept of community. He did not engage to the same degree as Willetts with the theoretical tension between liberty and market liberalism and conservatism, or as Blond with the market-redistributive effects that flow from having strong communities with strong local economies.

However, he arrived at a similar position to them both as a result of what he perceived to be the overly centralised and bureaucratic state which was a product of New Labour's political thinking. Such central state interference was described by Letwin as being a function of New Labour's "belief in the beneficence of the state", the belief that "the State is the great engine by which society will improve the condition of mankind" (Letwin, 2003b: 46). This belief in the state as a 'great engine' has strong links with the social democratic conception of social justice as being delivered through state intervention in order to broaden the distribution of opportunity and freedom, thereby resulting in greater equality.

However, for Cameronite Conservatives the effect of such state intervention was actually to erode society, not strengthen it. As David Cameron argued in his Hugo Young Memorial lecture on 10 November 2009:

"The paradox at the heart of big government is that by taking power and responsibility away from the individual, it has only served to individuate them. What is seen in principle as an act of social solidarity, has in practice led to the greatest atomisation of our society. The once natural bonds that existed between people - of duty and responsibility - have been replaced by the synthetic bonds of the state - regulation and bureaucracy."

(as quoted in Evans, 2010: 331) 
For Letwin as with Blond, the synthetic (rather than organic) bonds created by the central state are suspect because it is just this impulse to create equality which stifles local difference and the social bonds tying a community together. Central state intervention for Letwin therefore disempowers local communities and is blind to important local context and the local knowledge which Gray has identified as "a central value in any outlook that is truly conservative" (Gray, 1997: 39). The answer is therefore "to adopt... an attitude of thoroughgoing localisation" so that answers to problems can be "formulated locally and in response to the particularities of local circumstance" (Letwin, 2005: 41-42).

Similarly, Blond commented: "[I]f Conservatives are to take power from the market state and give it to the people, they must develop a full-blooded 'new localism' which works to empower communities and builds new, vibrant local economies that can uphold the party's civic vision" (Blond, 2009). This would require the scaling back of central state power and oversight, in order to produce "a society where there are thick local ties and lumpy local loyalties, not one which has been finely graded into individual grains moving frictionlessly past each other" (Willetts, 2003). The risk of unequal distribution of development opportunity and growth which so concerned New Labour and which may arise without strategic state oversight was apparently entirely outweighed by the supposed benefits of the abolition of "one-size-fits-all policies...imposed by the centre whether or not they work locally" (HM Government 2010: 5).

This would ostensibly create more freedom within communities to self-determine, to solve their own problems in a locally responsive way which acknowledges the individuality of local institutions and cultures which are distinct from the arbitrary boundaries of governance imposed by local manifestations of the state. This would also supposedly have the effect of strengthening local institutions and networks, thereby conserving them in accordance with the conservative impulse. Letwin called this vision 'the Neighbourly Society': "First and foremost a neighbourly society must be one which fosters and encourages the networks of support between individuals, families, neighbourhoods and community associations. It depends on active citizens. And gains enormous benefits from voluntary activity" (Letwin, 2003a).

Civic Conservatism and the Neighbourly Society therefore comprised a Burkean "revival of all those peoplesized institutions which stand between the individual and the state" (Willetts, 2002a), communities of local networks of active individuals bound together in neighbourhoods, with close ties being fostered through community action, and such ties serving to strengthen local institutions, identities and cultures. For Willetts, such a society would be a remedy for the 'enfeebling' of civil society, which "has suffered from twin attacks from an intrusive state and the remorseless spread of commercial values into every corner of life" (Willetts, 2002a). As David Cameron stated in a speech given in 2005: "I joined this party because I 
believe in freedom. We are the only party believing that if you give people freedom and responsibility, they will grow stronger and society will grow stronger" (Cameron, 2005). However, this rhetoric of freedom and responsibility was also used to legitimise cuts to public spending and thus also provided an ideological justification for the austerity programme which would come to characterise the Cameron governments.

\subsection{Summary}

This section has detailed the conceptual contestations and relations comprising the ideological renewal of the Conservative Party in the years leading up to 2010, with a focus on how this would come to relate to the programmatic and policy ideas for English town and country planning which are the focus of the next section.

The ideological renewal was in part a response to a decline in electoral fortunes of the Conservative Party and therefore a strategy to adjust its message accordingly. But it can also be seen in part as a serious inquiry into how the adoption of neoliberalism by the New Right had compromised conservatism, and how conservatism could be 'updated' by rediscovering an older, more One Nation discourse (with its statist element almost expunged) in order to stabilise the disruptive dynamism of the neoliberal emphasis on personal freedom and choice.

This required a greater emphasis on the concept of community and through it, an acknowledgment that the individual is responsible for the welfare and progress of others as well as for him/herself. The concept of community was decontested in such a way as to be very 'local' in nature. Through this, the concept of the Neighbourly Society was created, a vision for society in which individuals are knitted together into cohesive neighbourhoods through shared values, institutions and traditions.

The neoliberal form of liberty was thus contained and controlled; it was by no means rejected. There still remained the ideological imperative for deregulation, development, economic growth, choice, innovation, entrepreneurship and the creation of wealth. Indeed, it is these dimensions of liberty which the Conservative ideology sought to encourage in neighbourhoods through removing the 'artificial limits' imposed by the state. Theoretically, these qualities would work within the limits imposed, and would be given meaning, by local traditions and institutions.

Crucially, this meant that there was little theoretical space for a central state. It needed to recede to free up the conceptual space to be occupied by communities and neighbourhoods. However, as these communities and neighbourhoods would be bound together by local institutions and histories, at the ideological level the 
neoliberal conception of liberty was not allowed to atomise them into their individual components and dissolve community.

This conceptual amalgam had clear implications for governance. The central state was decontested as to be a limiter on local liberty and a means by which local diversity, difference and innovation is undermined. Therefore, there was a programmatic impulse to decentralise power away from the central state, and redistribute it at local and community levels, through local authorities, parishes and neighbourhoods and the creation of a more responsive local democracy.

This implied a rejection of the concept of the region as understood and introduced by New Labour, as the region as thus decontested was without democratic legitimacy and was therefore an unacceptable stateimposition, and its strategic focus was by definition removed from local neighbourhoods. Furthermore, the concept of the region was used by New Labour to think about means by which greater equality of opportunity could be delivered through greater strategic state oversight, which was antithetical to the updated Parliamentary Conservative Party ideology.

The ideological arrangement of concepts in Parliamentary Conservative Party ideology had little acknowledgement of strategic planning. There was only the central, and the local. There was nothing conceptually in-between. This was not problematic at the abstract level of ideology, which is concerned with concepts and their relational arrangement. Ideology does not, at the beginning, concern itself with practical matters (although it is necessarily oriented towards practice). It is, however, used to inform praxis as defined and delimited by programmatic and policy ideas. As we shall see in the next section, once ideology collides with real world problems, it must rearticulate in sometimes contradictory ways in order to arrive at practical solutions. 


\section{From Conservative Party Ideology to Programmatic and Policy Ideas for Planning}

The previous section gave an account of the ideological renewal of the Parliamentary Conservative Party under the leadership of David Cameron in the years leading up to 2010, with a focus on those elements which would have an impact on the town and country planning reforms introduced by the Conservative-led Coalition government. This section now analyses these reforms in order to demonstrate how the 'deep' philosophical ideas summarised in the previous section helped shape the programmatic and policy ideas for town and country planning during this period.

Relations between the levels of ideas will be identified, as well as areas of tension and contradiction which emerge as they go through the process of institutionalisation. This section will therefore illustrate the degree to which underlying tensions within the updated Conservative ideology were brought to the fore when various policy ideas were produced, and placed under scrutiny in the policymaking process.

The analysis will primarily draw upon a number of policy papers ('green papers') produced by the Conservative Party in the years preceding the 2010 election, as it is these which contain the most comprehensive summary of the policy programme for planning which would be introduced by the Coalition in its first two years of government, and it is this early period which is the focus of this section. The Liberal Democrats, who formed a coalition government with the Conservative Party in 2010, were much less prepared for government and did not therefore have a well-developed programme for planning.

The analysis will also draw upon the various House of Commons Communities and Local Government Committee inquiries into various aspects of the early Coalition planning reforms, as well as debates in the House of Commons and House of Lords, various policy papers produced, as well as 42 interviews conducted between 2013 and 2016 with civil servants, politicians, lobbyists and practitioners. While there will be some acknowledgment of the potential practical impact of the policy reforms, this is not the focus of this paper and so does not form a significant element of the analysis. The purpose of the analysis to demonstrate the role played by ideology in the formation, legitimation and institutionalisation of programmes and policies at the national level.

\subsection{The Conservative Party Green Papers}

By the time of the 2010 general election, the Conservative Party had had 13 years to ideologically reposition itself and work out a comprehensive set of programmes and policies relating to town and country planning. 
These found their expression in a set of three interlinked green papers which were produced in the run-up to the election: Control Shift - Returning Power to Local Communities (Conservative Party, 2009a), Strong Foundations - Building Homes and Communities (Conservative Party, 2009b), and Open Source Planning (Conservative Party, 2010).

Their authorship was overseen by Oliver Letwin who had been appointed by David Cameron to lead the Conservative Party policy review (Cameron, 2006). They therefore presented a seemingly integrated approach to addressing what the Conservative Party perceived to be the main problems associated with New Labour's policies as they related to planning, housebuilding and central-local government and community relations. As we shall see in this section, they were also shaped by the overarching conceptual (ideological / philosophic) framework and therefore bore the marks of the latent tensions between the various conceptual arrangements discussed in the previous section.

\subsubsection{The Programmatic Level of Ideas}

Key Conservative programmatic and policy ideas in the green papers relating to planning are summarised below.

- Deregulate - to simplify the planning system and make it more efficient so as to deliver growth.

- Develop - to promote growth through the planning system.

- Demystify - to clarify the planning system to make it more transparent and locally responsive.

- Decentralise - to give more plan-making powers to communities and neighbourhoods.

- Democractise - to make plan-making and planning decisions more democratically accountable to local communities.

In different ways, these programmatic ideas were related to the ideological level of ideas. The 'Deregulate' and 'Develop' programmatic ideas were linked to the relationship between the concepts of liberty and property in the ideology of the Parliamentary Conservative Party of the time, in a particularly 'negative' neoliberal form with the corresponding imperative to deliver economic growth (particularly through housebuilding and the increase in home-ownership which it was hoped would be achieved), and to remove the regulatory barriers which are perceived to be holding such growth and development back. 
The programmatic ideas of 'Demystify', 'Decentralise' and 'Democratise' were shaped more by their relationship with the concepts of community and the state in the overarching ideology, in that they show an apparent commitment to empowering local communities through the rolling back of the regional level of state 'interference' in local development, and giving more powers to communities to influence development in their neighbourhoods both through plan-making and through creating a greater degree of transparency and clarity in the planning decision-making process.

However, while the potential tensions between these various programmatic ideas (e.g. 'Develop' and 'Deregulate' vs. 'Decentralise' and 'Democratise') may be apparently resolved at the ideological level of concepts (as discussed in the previous section), when they are institutionalised through various related policy ideas, the underlying faultlines in the ideology may be clearly exposed as the next section will demonstrate.

\subsubsection{The Policy Level of Ideas}

The programmatic ideas shaping the policy changes set out in the green papers are traceable through the below policy ideas.

- Abolish "the entire bureaucratic and undemocratic tier of regional planning, including the Regional Spatial Strategies and national and regional building targets" (Conservative Party, 2010: 2). This is primarily related to the programmatic ideas of 'Deregulate' and 'Decentralise' - although it is also in potential conflict with the idea of 'Develop' due to the potential reluctance of local communities and politicians to plan for and deliver a sufficient number of new homes without the 'top-down' pressure of regional housing targets and regional plans.

- Create a "simple and consolidated national planning framework, which will set out national economic and environmental priorities, and how the planning system will deliver them" (Conservative Party, 2010: 3). This is primarily related to the programmatic ideas of 'Demystify' and 'Develop' - although it is also in potential conflict with the ideas of 'Decentralise' and 'Democratise' due to the potential for 'top-down' pressure from a national tier of planning policy on communities to plan for development and growth which may not be supported by local neighbourhoods.

- "[Give] local people the power to engage in genuine local planning through collaborative democracy designing a local plan from the 'bottom up', starting with the aspirations of neighbourhoods" (Conservative Party, 2010: 3). This is primarily related to the programmatic ideas of 'Decentralise' and 'Democratise' - 
although it is also in potential conflict with the ideas of 'Develop' and 'Deregulate', due to the potential reluctance of local communities to plan for sufficient numbers of homes, and due to the creation of more, not less, planning regulation at the neighbourhood level through Neighbourhood Development Plans.

- Introduce a presumption in favour of sustainable development (Conservative Party, 2010: 3). This is primarily related to the programmatic ideas of 'Deregulate' and 'Develop' - although it is also in potential conflict with the ideas of 'Decentralise' and 'Democratise' due to the potential effect of weighing the balance of decision-making in favour of development even where such development is not specifically supported in local or neighbourhood plans or by local communities.

- Amend the Use Classes Order "so that people can freely (i.e. without planning permission) change the use of buildings within a range allowed by the local community in its local plan" (Conservative Party, 2010: 6). This is primarily related to the programmatic ideas of 'Deregulate' and 'Develop' - although it is in potential conflict with the idea of 'Democratise' because by increasing the range of development which is permitted without the need for individual planning permission, the democratic process surrounding such development is significantly reduced, along with the potential for local neighbourhoods to influence such development through representations made as part of the planning application decision-making process.

The following section will discuss the interrelation of the various ideological, programmatic and policy ideas in greater detail and explore how the 'real world' processes of institutionalisation brought some of these latent tensions to the fore.

\subsection{Integrating the Levels of Ideas}

\subsubsection{Liberty, Economy, Property and the State}

The Conservative Party's programmatic and policy ideas for planning can be seen as an expression of the overarching ideological framework which formed part of the renewal of the Conservative Party after 2005. For the Conservative Party at the time, the perceived failure of planning to deliver growth was linked to its encroaching bureaucratisation and the proliferation of policy at national, regional and local levels which were framed as creating "bureaucratic barriers rather than enabling communities to formulate a positive vision of their future development" (Conservative Party, 2010: 1). However, as in the New Right period in the 1980s, the imperative of (negative) liberty did not imply a complete abolition of the planning system and the de-nationalisation of development rights. There was still a role for planning and the state. As Chancellor to-be George Osborne commented in a speech given to the Property Week Conference in 2006: 
"Of course, Government cannot simply withdraw and allow a free for all. Planning controls exist for good reasons not simply to protect the natural environment, important as that is, but also to protect the rights of existing property owners...I want us to look afresh at the planning system, and tackle the delays and obstruction that is damaging the competitiveness of our economy and the affordability of our housing. But I also want us to do so in a way that is environmentally sustainable...Provision of new housing must always be balanced alongside the protection of the natural landscape. You cannot create new property rights for some by devaluing the property rights of others."

(Osborne, 2006)

The programmatic impulse to liberalise and deregulate the planning system did result in institutional changes. This impulse partly manifested in the policy idea of amending the Use Classes Order, "so that people can freely...change the use of buildings within a range allowed by the local community in its local plan" (Conservative Party, 2010: 2). This policy idea would eventually be institutionalised through the increasing liberalisation of permitted development rights ("PD rights") under the Coalition government, such as the introduction of a broader range of PD rights for homeowners, and the permitted change of use between Use Class B1(a) offices to Use Class C3 dwellinghouses introduced in the Town and Country Planning (General Permitted Development) (Amendment) (England) Order 2013. Such liberalisation would give landowners greater freedom over how to develop and use their property (and therefore greater negative freedom from state intervention) and reduce the burden of bureaucracy. The practical effects, it was hoped, would be to increase the number of homes, bring brownfield sites into beneficial use, and improve economic growth (DCLG, 2011: 31).

However, an alternative way of reading the liberalisation of PD rights is provided by a planning lobbyist through a (perhaps somewhat hyperbolic) interpretation which suggests a more social democratic decontesation of the concepts of state, liberty and property: "What is permitted development relaxation about, it is about giving back state rights to landowners. It is the biggest giveaway of public assets in the post-war period. And it is not a sell-off, it is not privatisation, it is a gifting of billions of pounds worth of development rights" (Lobbyist A, 2015). This policy idea can therefore be interpreted through a competing ideological framework as the partial de-nationalisation of development rights and an attack on the very principles underpinning the 1947 system and, indeed, planning itself. From this ideological perspective, therefore, development rights are conceptualised as assets owned by the state, which should not be returned to landowners without compensation. 
We can see here how the liberalisation of PD rights engenders tension between competing ideological contestations of liberty, state, and property. However, it can also be seen as a manifestation of tension within the Conservative Party's ideological project itself, and related tensions between the programmatic ideas of 'Deregulate', 'Develop' and 'Democratise'. In short, the liberalisation of PD rights can be read as antithetical to the Neighbourly Society, as it prioritises the freedom of the individual landowner and the 'need for growth' over the rights of the neighbourhood as a community of individuals. This policy idea therefore points to the latent ideological tension between the imperative of individual liberty and private property on one hand, and the apparent 'rediscovery' of the One Nation concept of a social community on the other, as well as between competing contestations of the concept of liberty itself.

\subsubsection{Liberty, Community, Regions and the State}

The deregulatory impulse and the localist/community programme shaping the planning reforms seemed to be in closer alignment when the Conservative Party discussed them in more abstract programmatic terms than the more concrete policy idea of PD rights reform allow: "A Conservative planning system will be built upwards on the wishes of local residents, with clear democratic accountability and decisions being made from the bottom up. People will have greater control over the size, shape and 'look and feel' of their community, so they will be more supportive of new developments" (Conservative Party, 2009b: 20).

It is partly this imperative for decentralisation and empowering local communities to take responsibility for their neighbourhoods which produced the underlying distaste for New Labour's regional model in general, conflicting as it did with the Conservative Party's form of the localist impulse which, as we have seen, was intimately bound up with the concept of community and the link with local identities and institutions. One senior civil servant makes the following observation on the reasons for the Conservative distaste for regions as shaped by New Labour:

"The whole regional structures were very associated with the Labour government, and to some extent they soaked up some of the power from the local authorities, which...the Conservatives dominated at that time, so I guess if you were kind of very played into the grass roots Conservative Party, as Eric [Pickles] was, he would have, you know, constantly had for at least 5, 10 years this kind of outrage that there were these unelected, hardly visible regional bodies that were making decisions which your very democratically elected Conservative controlled council then had to follow...I think they felt that despite the fact these regional structures were populated by 
councillors, I think they felt there was a bit of a democratic deficit, and regions were a kind of a 'created thing', a beast of that Labour government..."

(Civil Servant B, 2015)

This was commented on by then-Conservative Minister for Planning Greg Clark when giving evidence to the House of Commons Communities and Local Government Committee inquiry into the abolition of Regional Spatial Strategies (“RSS"s), when he said that the Regional Development Agencies ("RDA"s) (which had been introduced by the New Labour government in 1998 in order to strategically plan economic development in the regions) were a "required creature of central government" without a sufficient degree of local accountability (House of Commons, 2011a: Ev 65). Similarly, he described RDAs in a speech in 2010 as follows:

"Despite the hard work and good faith of the people who worked in them, these were organisations that were flawed in theory, and ineffective in practice...First, their boundaries simply didn't reflect how economies work...Second, rather than arising from the grass roots up, Regional Development Agencies were imposed from the top down. Their very design was a reflection of Whitehall's ambitions and plans more than they were of local aspirations and needs. As my colleague in the Business Department, Mark Prisk has said they 'lacked any real democratic accountability to the citizens they (were) supposed to serve.' In some areas this led to a lack of real connection with local businesses, and a sense of disempowerment, frustration, and of being 'done to', rather than encouragement to take initiative."

(Clark, 2010b)

For Eric Pickles, the idea of an RSS particularly was "incompatible" with the concept of a shift from a "topdown to a bottom-up planning system" (House of Commons, 2011a: Ev 66). When asked in a personal interview what he found so objectionable about regional quangos and regional planning, Pickles said: "Wasn't working, and it was remote, and it was unaccountable, and it had power without responsibility. And I think it smacked of the arrogance of the state" (Pickles, 2016).

Of course, there was also a very pragmatic reason for the proposed abolition of RSSs in particular, and that was the significant amount of controversy generated by the perceived imposition of housing numbers through the regional strategies: 
"It was politically a very popular thing to do, so they were responding to Conservative shire councils who didn't want the housing targets and it was quite an easy political win at that point in time."

(Lobbyist B, 2013)

"[T] hey were so anti what they saw as top down heavy handed dictating, that came from not merely a theoretical dislike of regions, but the fact that in many of their constituencies their electorates were saying, 'we don't want this number of houses built', and in opposition the Tories saying, 'that's because we have to do it because the regional strategy tells us, and we're going to abolish the regional strategies'..."

(Politician A, 2015)

The Local Government Association ("LGA") was indeed "driving calls for having [RSSs] scrapped" (Politician B, 2015). The LGA had welcomed the publication of the Strong Foundations (Conservative Party, 2009b) green paper with a briefing which stated: "The LGA is pleased that the paper recognises the need for a strong locally driven aspect to house building, in particular the abolition of the regional planning system and regional housing targets" (LGA, 2009: 1). According to a Conservative politician and key influencer on the draft NPPF:

"It was a stupid idea about trying to design a country. Massively stupid idea. We had local plans that were being thrown out because they didn't have enough houses in and local plans being thrown out because they had too many houses in. Just ridiculous."

(Politician B, 2015)

This perspective was matched by that of former Conservative Secretary of State for Communities and Local Government Eric Pickles:

"About the housing targets...they were so arbitrary!...And they...didn't have buy in by the population, and they, in some cases, just smacked of political interference. And they didn't build anything, they didn't produce anything. What we basically wanted to do was to triangulate local government so that local people took a decision, otherwise what's the point of having local people?"

(Pickles, 2016) 
We can see in these perceptions that entangled with the objection to regional planning on the basis that it was undemocratic and an imposition from central government, was the perceived arbitrariness and misplaced rationality of the concept of regions as understood by New Labour. Furthermore, the activities of the RDAs and the RSSs were overtly interventionist and redistributive. This links with the Conservative suspicion of the innate rationality of New Labour's statism, and the very idea that such imposed rationalities should override the organic development of a functional economic area.

This deep seated antipathy towards regions and any form of regional planning (at least on the part of Eric Pickles and Conservative local authorities) would be demonstrated by the swift announcement of the revocation of RSSs on 6 July 2010 (Pickles, 2010; Quartermain, 2010) (RDAs would be abolished through the Public Bodies Act 2011 which came into effect on 31 March 2012). This was the beginning of the institutionalisation of the related policy idea from the green papers, and therefore the programmatic ideas of 'Deregulate' and 'Decentralise' which showed a seeming lack of appreciation of the potential conflict with the imperative for development, particularly of new housing.

\subsubsection{Regions, Liberty and Democracy}

However, the view of the Conservative Party's apparent ideological aversion to regions is seemingly challenged by the fact that the Coalition and the subsequent Conservative governments have also introduced forms of 'larger than local' (i.e. regional or sub-regional) thinking such as Local Enterprise Partnerships, Growth Deals and City Deals which can include devolution deals to city regions and combined local authorities which give greater powers, funding and flexibility to these areas to deliver specific outcomes. Crucially, the devolution deals include "strategic planning arrangements in many areas" (Johnston, 2016).

For example, the devolution deal agreed with Liverpool City Region (comprising six local authorities and the Liverpool City Region Local Enterprise Partnership) in November 2015 includes "powers over strategic planning, including the responsibility to create a Single Statutory City Region Framework, a Mayoral Development Corporation and to develop with government a Land Commission and a Joint Assets Board for economic assets" (Gatley \& Clark, 2015).

These measures were in alignment with the Treasury's agenda to create a 'Northern Powerhouse' to “create a balanced, more healthy economy for working people across our United Kingdom” (Osborne, 2015). Although not described as such, these policies are manifestations of regional and spatial thinking. However, they are associated with a fundamentally different understanding of the concepts of the region, liberty and the state to that which shaped policy in the New Labour days. 
Whereas the concept of the region for New Labour was linked to the imperative for strategic central government oversight as manifested through targets and an apparent democratic deficit, for the Conservative Party the concept of the region is decontested through a more localist lens which is not as constrained by the concepts of equality and (state-secured) 'social justice', and emphasises local (and regional) freedom from central government intervention and control to create opportunities for selfdetermination and development.

Conservative Party policy regarding regions has thus been presented as a means by which local areas are given the freedom to come together to form regional forms of governance and identify and act on regional priorities should they choose to. There is no statutory requirement. The type and form of any devolution deal, indeed whether they exist at all, is therefore subject to negotiation with central government and, therefore, variable. We see here the "role of local level experimentation in governmental forms and behaviours is simultaneously a form of cooptation and liberation in allowing discretion in how these processes of assemblage and search for legitimacy are constructed" (Allmendinger, Haughton \& Shepherd, 2016: 49).

Crucially, in the case of devolution deals, these forms of governance are given democratic legitimacy through the strong encouragement by central government that such regions elect a mayor where substantial powers are devolved to areas around cities:

"Having an elected mayor gets the government off the hook. So the person who sits at the top is elected, there is no regional deficit, it is all legit. Without an elected mayor you are back to unelected bodies making decisions."

(Practitioner A, 2015)

This form of 'acceptable' regional thinking is therefore legitimised through its relationship with the programmatic imperatives to 'Democratise' and 'Decentralise' the planning system, and its decoupling from an understanding of the role of the state as being closely linked to that of society.

\subsubsection{Neighbourhoods, Community, Conflict and the State}


It was the desire for 'decentralisation' and 'democratisation' which lay behind the introduction of a new approach to plan-making starting with the aspirations of the 'more local than local' level of neighbourhoods. This, it was hoped, would perform the function of bringing a neighbourhood together (which the Open Source Planning green paper defines as "villages, towns, estates, wards or other relevant local areas" (Conservative Party, 2010: 2)) in an institutionalised form to determine its own future and maintain a Neighbourly Society: "By giving people more power and control over the services that are delivered in their areas, we can inspire a new spirit of civic pride in our communities" (Conservative Party, 2009a: 2). This was part of a broader vision of a new Britain "where power is shared and communities are once again trusted to be in charge of their own destinies" (Conservative Party, 2009a: 8).

This programmatic impulse would eventually be institutionalised through the idea of neighbourhood planning and its related policy idea of introducing a new tier of optional but statutory plans at the neighbourhood level, which was introduced through the Localism Act 2011. When introducing the Localism Bill 2011 to the House of Commons for its second reading, Eric Pickles stated:

"The Bill will return the planning system to the people. Targets do not build homes, and regional plans do not get communities involved. Today, we have an adversarial, confrontational system, fomented on mistrust and a sense of powerlessness. It is simply not working. The Bill will therefore create genuine neighbourhood planning, by which the community will develop in ways that make sense for local people. Instead of instructions being handed down from on high, the Bill will offer incentives to invest in growth."

(HC Deb 17 January 2011, c563)

For the Conservative Party, the introduction of neighbourhood planning would therefore perform the function of helping to "change the adversarial culture of planning" and "develop an approach to planning that allows for much greater collaboration between the various parties" (Conservative Party, 2009b: 25). For the Conservative Party "building local plans from the bottom up so that they genuinely reflect the will of the people...will help communities to come together so they can solve their collective problems together" (Conservative Party, 2010: 8).

However, as well as strengthening local neighbourhoods and institutions, a desired consequence of neighbourhood planning was that "if communities lead development, local people will take greater ownership and more homes will be built as a result" (Conservative Party, 2009b: 6). It was also hoped that it would encourage local communities and neighbourhoods to find "imaginative and sustainable solutions 
to the inevitable tensions between development and conservation" (Conservative Party, 2010: 1). In short, it was envisioned that a closer and more neighbourly community with greater powers of self determination would help to take the conflict out of the planning process, and would therefore result in more development and growth without the need for central imposition. For Greg Clark, such an approach would enable the Conservative Party to achieve two apparently competing programmatic objectives: "By moving from conflict to collaboration, we can be both prodevelopment and prolocalist...decentralisation and development. I believe in them both. And I believe that they can and should reinforce one another" (Clark, 2010a). However, the introduction of a new tier of neighbourhood planning would increase the amount of planning regulation at local level, which brought the policy idea in to conflict with the programmatic imperative to 'Deregulate'.

\subsubsection{Town/Country, Property, the Plan and the State}

There is also evident within the green papers the old tension between town and country. On one hand, there are repeated references to the need to protect the countryside, and the 'green belt' in particular, from the threat of development. Unsurprisingly, the green papers pledge that Conservative Party national planning policy would "maintain national Green Belt protection....and other environmental designations which protect the character of our country's landscape, stop unsustainable urban sprawl and preserve wildlife" (Conservative Party, 2010: 3). Indeed, green belt protection was off-limits for reform, as indicated by Policy Influencer A who was involved in the drafting of the National Planning Policy Framework ("NPPF"):

"I think there is an inherent tension, because on the one hand the purpose of Open Source Planning and the NPPF reforms was to deliver more development on the ground. But on the other hand there was this antagonism to top down targets...So there was inevitably some debate over whether we should look at green belt policy in the NPPF but basically we were warned off that, in that we couldn't really touch that, and ministers were not going to go anywhere near it."

(Policy Influencer A, 2015)

As indicated in this quote, lurking alongside the more collaborative and community focused approach to planning set out in the green papers, and the pledge to protect the countryside and the green belt from unwanted development, there was the parallel imperative for housebuilding and economic growth which was embodied in the proposed 'guiding principle' of the presumption in favour of sustainable development, to automatically apply where local plans have not been completed within a prescribed period. In this instance, according to the green papers, the local planning authority in question "will be deemed to have an 
entirely permissive planning approach, so all planning applications will be accepted automatically if they conform with national planning guidance" (Conservative Party, 2010: 9).

This approach was one of the key means by which the "inevitable tensions between development and conservation" (Conservative Party, 2010: 1) and localism and growth was dealt with in the green papers, and also reveals that the Conservative Party's vision of localism was not absolute: as indicated in its broader ideological conceptual framework, with additional freedoms come additional responsibilities. In the Parliamentary Conservative Party's view, therefore, if local planning authorities do not take their responsibility to plan positively for growth by preparing an up-to-date local plan, then national planning policy and the presumption in favour of sustainable development would apply.

This of course meant that there would be the potential for community views to be overridden by this presumption should there not be a local plan representing these views in place. The proposal for the presumption to apply where there is no up-to-date local plan simultaneously retained the plan-led system, but also undermined it in instances where local planning authorities have failed to prepare local plans which reflect up-to-date national policy. This would become a significant issue of contention in the process of the institutionalisation of the policy idea of the strengthening of the presumption in favour of sustainable development through the NPPF, with the government facing strong opposition from traditionally Toryassociated institutions such as the National Trust and the Telegraph newspaper and the proposed presumption was finally enshrined in the adopted NPPF in moderated form.

The move from a 'top down' system of planning and housing delivery to a more 'bottom up' system, as exemplified by the abolition of the RSSs and their housing targets, and a form of plan-making in which neighbourhoods would have a greater say can be seen in part as an attempt by the Conservative Party to reconcile the deep tension between a neoliberal form of negative liberty with its emphasis on individual freedom, economic growth, deregulation and the receding state and the Conservative understanding of community, with its emphasis on the importance of local institutions, histories, traditions and identities.

However, when combined with the perennial tension between the concepts of town and country, this conflict is dramatically heightened. This is due to the intersection of traditional conservative concerns about the loss of institutions and traditions with the threat to 'deep England' (Stevenson, 2005) posed by new physical development and, perhaps, the social qualities of inhabitants of new housing development. Also important, of course, is the much more pragmatic concern with electoral fortunes of the Conservative Party 
in the context of traditional Tory supporters residing in rural shires where there is pressure for greenfield development.

Therefore, the latent tension at the heart of the Coalition Conservative ideology can be seen as also lying beneath the surface of the Conservative Party's proposed (and executed) planning reforms: on one hand, there was the imperative for economic growth and housebuilding, deregulation and development. On the other hand, there was the imperative for local institutions, neighbourhood planning and the primacy of local decision-making.

The degree to which this tension impinged upon and distorted the eventual institutionalisation of legislative and policy change is illustrated in debates over the status of new statutory Neighbourhood Development Plans ("NDP"s) during the passage of the Localism Bill. In isolation, the Conservative Party's emphasis on communities and localism meant that 'ideally' the NDPs (once introduced in the Localism Act 2011) should have been able to plan for as much or as little development as desired by the neighbourhood. However, when related to the programmatic imperatives of growth and development, this could potentially conflict with the need for more homes. This resulted in an adjustment to the policy relating to NDPs which sought to ensure that they were not used to prevent the delivery of housing development.

A member of a professional lobbying group states:

"I think they then had [a] ...moment where they thought, 'Oh bloody hell they're not going to come up with 200,000 homes' or whatever the number was at the time, and then the sort of Neighbourhood Planning and other elements, changed and Neighbourhood Planning when it actually came out was, 'Yeah you can write a Neighbourhood Plan but it's got to deliver at least what is in the Council's plan maybe more, so it can't be negative'. And then what also came out of that was the duty to cooperate as a substitute, or sticking plaster for strategic planning."

(Lobbyist L, 2015)

The Conservative Party had stated in Open Source Planning that it would introduce a 'duty to cooperate' in order to ensure "that there is a sensible conversation between all those involved in shaping neighbourhoods and the landscape" (Conservative Party, 2010: 3). The duty was introduced in the Localism Act 2011, and also appears in the NPPF. It was the government's intention that this duty would fill the strategic gap left by the removal of the 'top down' RSSs and allow a more localist response to strategic 'cross boundary' planning issues. This duty was imposed alongside a requirement to plan to meet 
objectively assessed development needs, including housing. So rather than 'imposing' the housing numbers through regional planning, the housing numbers would have to be identified and planned for by each individual local planning authority, albeit through following the duty to cooperate.

In this way, the government could stick to its ideological commitment to remove regional planning and introduce a more localist planning system while still allowing for the pragmatic necessity of some form of cross-boundary working. However, the duty was by no means a replacement for strategic or spatial planning as enshrined in the 2004 Act system. The Select Committee's report into the draft NPPF stated: "Not everyone was convinced, however, that the duty to co-operate would be an adequate replacement for the 'larger than local' view of planning hitherto provided by Regional Spatial Strategies" (House of Commons, 2011b: 46). Stuart Hylton of the Planning Officers Society noted that "a duty to co-operate is not the same thing as a duty to agree", and argued it was wrong to assume "that agreement is always there for the reaching, if you just consult each other hard enough" (as quoted in House of Commons, 2011b: 46). Some form of top-down influence, it is suggested, is therefore required.

In the wording of the NPPF, the duty to cooperate and the requirement to plan for objectively assessed housing need was used as a means by which the government could introduce policy change which is apparently in accordance with its localist/community ideological impulse, while seeking to reconcile the conflict with the broader requirement to deliver more homes and economic growth, and without relying on regional planning. These policy ideas adopted by the Coalition can thus be interpreted as pragmatic responses to ideological, political and practical constraints the government was working under. Insight into the interplay of these factors is provided by a member of a think tank:

"In...thinking about how they can make localism and housing growth work and chime together, the government has had to shape its policy, so you're more and more in the bracket of getting housing growth through local consent, rather than imposed top down ...you kind of start with your position which is, you know, ideologically driven in parts, and then you think about the sort of practical things you can do on the ground to make it work, to not undo what you are trying to do in other policy areas, so in this case in the space of getting more homes built."

(Lobbyist G, 2015)

This account evokes a feedback loop through ideology, programme, policy, pragmatism, interests, and back again. It hints at the role of ideology as providing a 'framework of acceptability' against which programmes and policies can be assessed alongside pragmatic issues and interests, thereby helping to identify, 
distinguish between and select and communicate a strategy or policy solution. Crucially, in the case of the broad objective of 'deliver more housing', there has been little change since the New Labour government, which wanted to achieve the same. It is therefore not the ends of policy, but the means of policy itself which have changed in this instance. The policy change is a function of a shift in the terms in which the objective, the reasons that objective is not being met, and what therefore needs to change, is understood. In short, it is function of a change in ideology.

\subsection{Summary}

Oliver Letwin said in an interview given in 2008 that: "[T]here is a recognisable Conservative disposition. For us politics is not a question of translating an ideology into results, but a question of identifying what are the real life problems facing people and how they are to be addressed" (Letwin \& Finlayson, 2008: 71). However, this section has demonstrated that ideology plays a significant role in shaping the terms by which such 'real life problems', and the means by which they should be addressed, are understood and legitimised.

This section has demonstrated how the Conservative Party's and Coalition's ideological framework set the limits within which the programmes and policies operated, or set the 'frame of acceptability'. Hence the planning reforms were presented discursively in a way which was apparently consistent and unified within the various overarching discourses of 'Deregulate', 'Develop', 'Demystify', 'Decentralise' and 'Democratise'. These programmatic objectives were presented as means by which a Conservative vision of a 'Neighbourly Society' could be both delivered, and co-opted into helping deliver more neoliberal growth objectives.

However, there remained the underlying tensions which the ideology at a more abstract level sought to resolve. These would become more apparent and harder to obfuscate once the ideology was translated into programmes and policies. A key area of tension here remains that between town and country, growth and localism and the related concepts of liberty and community. There is an ideological imperative for economic growth and building more homes, yet there is also an ideological imperative for empowering local communities who may resent the incursion of town into country. The solution of providing more planmaking powers was legitimised and communicated as a means by which this tension could be reconciled without having to employ the coercive powers of the central state.

This section has also demonstrated how ideology, programmes and policies do not operate in isolation from pragmatism and interests. Indeed, it is part of the overall theoretical framework of this paper that these elements are not distinct from ideology, but are in fact shaped by ideological frameworks. There is a dialectical relationship at play, expressed through the creative activity of ideas and concepts. For example, 
on one hand the abolition of the RSSs can be seen as a simple pragmatic response to political pressure from disgruntled Conservative local authorities in the south east of England. But on the other hand, their abolition was theorised, legitimised and communicated through an ideological framework which sought to present the problem in a certain way and therefore exert power and control over the terms in which the problems and solutions were understood.

The policy changes around the concept of the region is a case in point. The Conservative Party's discourse and ideology initially sought to decontest the concept of the region in such a way which aligned it with an overly centralised state, democratic deficit, the suppression of individual and community identity, the imposition of unwanted development, and a technocratic form of rationalism which overruled more natural, or organic economic areas. This ideological discourse legitimised the abolition of regional planning, and allowed the later re-creation of a form of regional planning on different and more ideologically acceptable terms. This included a more organic 'assemblage' of regional governance in the form of city regions and devolution deals. The role of ideology here is again to set the terms by which a problem is understood and communicated, and to legitimise the replacement policy.

However, in this analysis we have also seen the limits of ideology. Ideology, programmatic and policy ideas do not encompass the entirety of thought and action when it comes to policy change. Short term political pressures, bargaining and error rather than conspiracy also play a role. We see this in the adjustment to the relationship of Neighbourhood Plans to Local Plans. 


\section{Conclusion}

This paper has engaged with the problem of the change and paradoxical stability of the institution of national English town and country planning by theorising that this phenomenon is linked with national political ideologies. This has been through a study of the relationship between dominant national political ideologies as held by elements of parliamentary parties in central government, and changes in the institution of national English town and country planning. The analysis has therefore been concerned with political ideologies and their relationship with the institution of national English town and country planning over time.

Heywood (2012: 4) cautions that "much confusion stems from the fact that, though obviously related, 'ideology' and 'ideologies' are quite different things to study'. He argues that to study 'ideology' is to "consider a particular type of political thought", whereas to study 'ideologies' is "to be concerned with analysing the content of political thought" (Heywood, 2012: 4 - emphasis in original).

In Heywood's terms, the paper has primarily been concerned with analysing the changing content of political thought as articulated in the ideology of the institution of national English town and country planning. However, in order to consider the content of ideologies and to analyse their relationship with an institution, one must unavoidably engage to some extent with the other side of the analytical coin and think about what functions are performed by ideology as a particular type of thought.

So while the distinction drawn by Heywood is a helpful one it does perhaps overstate the case. Ideology as an abstract concept and ideologies as applied manifestations of this concept are inextricably linked to the extent that it is simply not possible to study one without considering the other. It is a matter of being clear about analytical and methodological emphasis.

The emphasis of this paper has been on the content of political ideologies and the content of the ideology of the institution of national English town and country planning. This paper therefore primarily offers an empirical account of this institution through an analysis of how national political ideologies have sought to decontest concepts of importance to the institution, and how this has been manifested in the institutional structure during periods when particular ideologies were dominant in British government during two 'snapshots' of English political history. However, despite this methodological and analytical emphasis, the paper does also offer some potential theoretical insights into the various roles ideology as a type of thought 
has played within the institution over time. This conclusion discusses some of these insights, as well as some of the lacunae and limitations of the morphological approach adopted in this paper.

\subsection{The Conceptual Structure of the Ideology of the Institution of English Town and Country Planning Over Time}

The research adapts Michael Freeden's method for the analysis of individual political ideologies so as to analyse the ideology of the institution of national English town and country planning. To achieve this, it has theorised the institution as being partly an amalgam of elements of various political ideologies. Political ideologies are in turn theorised as comprising articulations of ideologically-loaded essentially contested concepts. Therefore, just as the 'meaning' of a political ideology derives from the relational structure of its conceptual morphology, the 'meaning' of the ideology of the institution partly derives from the relational structure of the ideological elements which shape it. The paper has sought to analyse this structure, and how it has adjusted over time in response to its adjustment by dominant ideologies occupying positions of power within the central state.

It has been argued that in the decades prior to the institutionalisation of the 1947 system, there was popular and elite political debate regarding the relationship between liberty, society, property and the state. For different reasons, the three main British political ideologies of liberalism, conservatism and socialism came to agree at an abstract level on the general principle of increased state intervention in personal liberty and private property in the interests of society, although this agreement proceeded from different articulations and decontestations of these concepts. The precise form and extent of intervention was therefore contested. Nevertheless, fractious agreement over the principle of increased state intervention in private property and individual freedom helped shape the gradual social reform movement of the late nineteenth and early twentieth centuries, of which the planning movement was a part.

These political concepts were core to the early English planning movement, which combined them with a special concern with the relationship between town and country. The result was a progressive social movement which was preoccupied with the creation of a new society in which the community would be free from the oppression of urban degradation, and would be free to enjoy the benefits of country-style living. This would be achieved partly by protecting country from town and industry.

There was in these early years a growing consensus regarding the need for some form of planning, in an abstract accord chiming with that which helped propel the broader reform movement. The early planning movement was therefore a strange mix of radicalism and conservatism, and it is this which would help 
secure its legitimacy and continued survival. There was little emphasis on the concept of the state in this early movement, but as planning gradually became institutionalised in the early twentieth century through professionalisation, legislation and policy, the concept of the state assumed a more central structural position.

By the time of the establishment of the 1947 system in the context of the 'post-war consensus', the concept of the state had assumed core structural importance to the ideology of the institution. The proper nature of the relationship between individual liberty and society was still contested, but the potential dynamism was stabilised by a broad consensus over the need to protect country from town and industry in the interest of the public good and the environment. Stabilised in this way, the concepts of liberty, property and the state were sufficiently decontested so that there was an acceptance of a programme of state control of development rights in the interest of planned reconstruction and the protection of the community from the harmful effects of industrial agglomeration. The concept of the economy was therefore also important to the ideology of the institution of planning, and planning was then understood as acting to remove impediments to reconstruction and growth.

Despite dynamism around the financial provisions of the planning system in the post-war period, the broader 'post-war consensus' regarding policy means provided a relatively stable political context during which the institution could consolidate and firmly establish itself. However, the consensus crumbled in the 1970s under the pressure of a failing economy and by the time the New Labour government was elected in 1997, the British New Right governments of Margaret Thatcher and John Major had shifted the political centre ground which was now partly shaped by neoliberalised ideology.

The New Labour government retained a neoliberal form of the concept of liberty which remained at the core of the ideology of the institution of national English town and country planning. However, it was stabilised and tempered by rearticulation and the insertion of a social democratic concept of community. This influenced a thin form of the concept of social justice which when linked with the now neoliberalised concept of the economy (which was framed as being a means by which social justice objectives could be secured) and the concept of the state, influenced programmatic and policy ideas aimed at redistributing freedom and opportunity more equally. For the institution of planning, this would be secured through increased central state oversight and intervention, in particular through regional planning.

Although in some ways a continuation of the New Right agenda for planning in the mid-1990s, the institution under New Labour came to be criticised by the Conservative Party while in opposition as being 
overly centrist and too 'top-down'. This critique linked with a broader ideological repositioning of the Conservative Party which was preoccupied with the tension which had been emphasised in conservatism by the development of an aggressively neoliberal concept of liberty in its ideology. This ideological renewal of the Conservative Party was based on the apparent rediscovery of One Nation concepts of community and society which were called upon to protect valued conservative institutions from destruction by the excessive social and economic dynamism of a neoliberal concept of liberty, while simultaneously filling the conceptual space left by a receding state.

This ideological level of abstract political thinking (which was also aimed at helping the Conservative Party secure electoral success in a post-New Labour political environment and helped legitimise a policy programme aimed at reducing the size of the state) therefore had an innate apparent ideological bias towards the local over the central. This manifested in programmatic ideas relating to town and country planning which were aimed at strengthening local democracy and freeing local authorities and communities from 'unnecessary' central state oversight and interference. This was a function of the intersection of a controlled form of neoliberal liberty, and altered concepts of society and community in comparison with the New Labour years. This core structure also influenced the programmatic idea of removing the regional structures of planning which had been built in the New Labour period, while allowing for the more 'bottom up' assemblage of new forms of regional planning and governance based on incentives and deal making between local and central levels of the state.

\subsection{Concepts, Contestation and Consensus}

The analysis has shown that the ideological morphology of the institution of national English town and country planning in the periods of study has changed as dominant ideologies have changed in central government. This is not, of course, a surprising finding. The research has been concerned with theorising the nature of the relationship between political ideologies and the institution of national English town and country planning, detailing the conceptual structure of this relationship, and thereby providing an account of how ideology manifests in institutional changes.

This paper has argued that as new governments have been elected, or as ideas have changed over the course of the same government, the institution adjusts in response to the ways in which the concepts which are of core structural importance to the institution are partially but sufficiently decontested by the ideologies of these governments. New concepts may be added to the structure of the institution, thereby further adjusting its ideological structure. The analysis has therefore shown that the structure of the ideology including the concepts of town, country, society, liberty, property, and the state has remained in-tact, but that these 
concepts have been (partially yet sufficiently) decontested in different ways, and in different relational structures over time.

Of course, what this form of analysis does not address is the process by which this relational structure shifts, and the means by which the policy ideas are institutionalised. This would require a form of analysis which focuses on the specific political discursive processes which compete for influence during particular moments of policy change, including a stronger acknowledgement of the role of civil servants and the priorities of competing government departments - but this has not been the focus of this paper (for further analysis, see Shepherd (2016)).

However, the paper has shown that due to the enduring presence of concepts of structural importance to the ideology of the institution of national English town and country planning, the institution has endured despite its structure being adjusted through various partial but sufficient decontestations of its core concepts. Its core concepts therefore paradoxically both ensure its continued change and its continued stability. These concepts are deeply ideological, and so are subject to change when they are encountered by different dominant political ideologies. However, the institution has developed and endures precisely because these core concepts are of such importance to different political ideologies.

For different reasons, competing political ideologies can accept the need for the institution of national English town and country planning - this is partly a function of the enduring presence of the concepts of property, town and country in which almost everybody has an interest, and without which the institution would cease to exist in any recognisable form. However, despite this apparent stable foundation, there is little agreement as to the precise form the institution should take. In other words, there is little agreement as to the precise articulation of these concepts and, therefore, the precise form, function and meaning of the institution. The concepts comprising the institution are in ongoing contestation both between different ideological frameworks, and within the 'same' ideological framework over time, influencing ongoing change and paradoxical stability. This can be theorised as resulting in frequent change at the 'periphery' (as manifested in policy changes), both as a function of shifts at the core, and as a function of the institution's interface with the changing 'real' world context.

What this analysis has argued, therefore, is that there are potentially many more varieties of ideological constructs within the institution than simply three (e.g. Foley, 1960; McAuslan, 1980). The institution has accrued different ideological elements over time, so that now it is possible to articulate it into many forms in response to the ideological biases of the beholder or the preferences of different central government 
departments. This ideological flexibility has arguably ensured the continued survival of the institution, and has helped create the strong degree of local discretion which is possible (and, indeed, desirable) in planmaking and development management decisions in England.

The analysis can therefore be seen as peering behind the veil of what Reade (1987) called the 'holism' of the ideology of planning, to reveal the fragmentary complexity of what this apparent comprehensiveness conceals. This begs the question as to what degree the ideology of the institution of national English town and country planning is coherent. If its conceptual structure is capable of being adjusted into a broad variety of permutations, can it be said to have any degree of coherence of form and consistency? Can it be said, therefore, to be an institution?

\subsection{Ideology, Coherence and Change}

The analysis in this paper shows that the ideology of the institution of planning can be assembled into different structures in response to its engagement with different historical contexts, circumstances and problems. This may result in contradictory imperatives, yet these rest on a core which does not lose its integrity - the 'same' concepts are present, yet they are arranged and interpreted differently. In this sense, the ideology of the institution acts in the same way as ideology in the abstract, as the following quote from Michael Freeden suggests:

"[B]ecause political reality is to an important degree a function of what human beings, the organizers of that reality, choose to select, the ranges a specific concept covers will differ from case to case. Consequently ideologies are in part impervious to logical criticism. Once a path of argument is condemned as logically flawed, the cultural pluralism of conceptual intensions allows alternative paths to be established, until they too are condemned. Indeed, two contradictory paths may lead out of and into the same core, as with extreme conservative opposition to the European Union predicated on a xenophobia insulating against change, and conservative support for it predicated on improved economic performance contributing towards stability."

(Freeden, 1998: 71)

The institution of national English town and country planning, like the political ideologies to which it is related, does not have to be entirely consistent or coherent. It is not predicated upon rigorous philosophy, but ideology, which is philosophy's unreliable doppelgänger and 'impervious to logical criticism'. Indeed, ideology in the abstract and the institution of planning must in fact be inconsistent and incoherent. These are necessary qualities of both. For ideology this is because it seeks to simplify the complexity of the social 
and political world through imposing containing myths and narratives. Yet these are by their nature provisional, so their underlying fault lines are exposed when ideological programmes are put into action and the complexity of the social and political world (particularly that found in pluralist democracies) intervenes to fracture the apparent coherence of the ideological vision. Un-tested in the abstract, ideologies may appear more or less coherent and able to achieve a wide range of competing objectives. But when forced to engage with specific issues, they contort into sometimes apparently contradictory positions in an attempt to suppress, defuse or displace challenging ruptures and establish legitimacy.

Similarly, planning itself seeks to simplify complexity in order to create a plan and enable development decisions to be made. As an idea, it holds within it many contradictory promises, and these contradictions are made manifest in individual policy and development management decisions. Yet this is necessary in order for the institution of English planning to function. It must have underlying ideological flexibility (or a degree of incoherence) in order to win support and in order to deliver development outcomes which are suitable to the specifics of the merits of a development proposal and to local context. As a practice, planning is therefore a site of ideological and discursive struggle where competing agendas across a wide domain of influence jostle for primacy resulting in a fragmentary policy and legal framework (Lees \& Shepherd, 2015). Planning itself may not be an ideology, but it is inherently ideological in how it functions to seek to 'fix' certain agendas and indeterminate political meanings in national policy, and individual plan-making and development management decisions, decisions which are underpinned by attempts at ideological 'decontestation' and are part of an ongoing and futile drive to "finalize collective affairs" which is a fundamental characteristic of 'thinking politically' (Freeden, 2013b: 22-23).

We should not therefore be surprised at the tensions and contradictions lying at the heart of so many stages in the history of the institution. The Conservative Party's recent incarnation of the institution is just one example of the underlying conceptual tensions within both its ideology, and the ideology of the institution of national English town and country planning. At no point have the contradictions within planning been resolved - they have been struggled over and have shifted and expressed differently in different periods, in relation to different cultural, political and economic contexts.

\subsection{Ideology as Frame}


The latter part of the paper has shown how the various conceptual relations and structures at the philosophical (or ideological) level of idea allowed for the creation of a series of programmatic agendas for planning which found their way into policies and legislative changes which adjusted the institution of planning after 2010. The ideological level therefore acted as a frame, setting the limits of what was politically acceptable. This frame was not rigid, but allowed for some degree of flexibility in setting the programmatic agenda and, crucially, in the specific form and function of policy ideas. This was demonstrated in the process of the institutionalisation of the NPPF, which was an expression of the programmatic impulses to deregulate, demystify, decentralise and develop.

The NPPF encountered particular resistance regarding the perceived over-emphasis on the programmatic idea of encouraging development and economic growth (particularly through the policy idea of the 'presumption in favour of sustainable development'), and this resulted in some adjustment to the precise form of this particular policy idea, but it was eventually institutionalised without deviating from the general programmatic direction set by the overarching ideology. Another example is the institutionalisation of the policy idea of Neighbourhood Development Plans, which were eventually introduced with a clarification regarding the requirement that they comply with local plans to ensure that they were not used to prevent new housing development. The policy idea therefore shifted and contorted through the process of institutionalisation in order to prevent the programmatic idea of 'Decentralise' from too starkly conflicting with the programmatic idea of 'Develop'. There remained tension between these two programmatic ideas, but this tension was contained within the broader ideological framework.

Ideology, in these examples, therefore acts as a frame, or 'master-narrative' for programmatic and policy ideas. The function of ideology in these examples of institutional change was therefore to curtail the range of possible interpretations of the nature of, and problems created by, the institution of national English town and country planning, and also to limit and direct the range of possible solutions as manifested through programmatic and policy actions.

\subsection{Ideology, Interests, Pragmatism and Legitimation}

Although not a primary focus of the research, the analysis has engaged to some degree with the relationship between ideology and interests. One example of the intersection between ideology and interests is the abolition of Regional Spatial Strategies ("RSS"s) and the housing targets contained therein. On one level, Eric Pickles may have been acting with some degree of personal interest in removing the housing targets, as it was important that the government retained the support of its local councillors who were agitating for this change. 
However, the argument for their removal was couched in ideological terms, so that RSSs and their housing targets were attacked as an example of New Labour statism, lacking in democratic accountability. Eric Pickles therefore arguably interpreted his own political interest in ideological terms. Or alternatively, he simply used an ideology-infused narrative to provide some of the discursive power required to legitimise the implementation of this particular policy change.

This links to a broader un-answered question at the heart of the research: to what degree do politicians really believe in what they say and do, and to what degree are the speech and actions of politicians simply a means for them to secure and retain political power? Was New Labour's Third Way a 'sincere' ideology, or was it synthesised so as to win over more voters? Did the ideological renewal of the Conservative Party in the years leading up to 2010 genuinely reflect the beliefs of people like David Willetts, Oliver Letwin and David Cameron, or was it all a ploy to win the next election? Does a later shift to a more centralist approach to planning and plan-making in the Housing and Planning Act 2016 betray a calculated cynicism in the previous localism agenda, or a change in strategy in the face of failing policy?

However, for the purpose of this paper, such questions are moot. Indeed, such is the range of individuals involved in these political agendas, it is unlikely that there is any single answer. Political ideologies may be both sincerely and cynically, consciously and unconsciously held. What this paper has explored is the way in which such collective ideologies can shape the terms by which personal interests are conceived, a policy problem is communicated, and the way in which it is used to construct, legitimise and deliver institutional change.

\subsection{Ideology and History, Continuity and Change}

The analysis reported in this paper focuses on certain 'snapshots' in the history of English planning - the institutionalisation of planning in the post-war period and the institutional shifts after the election of the coalition government in 2010. These 'snapshots' are contextualised through a discussion of some of the key ideological and planning debates in the years preceding them. This approach was taken so as to be able to trace the shifts in meanings of concepts core to planning over time. However, this is not to say that the conception of history underpinning this analysis is necessarily developmental in the sense of proceeding by a series of steps towards a state of greater ideational or social and material emancipation.

However, the conception of history in this paper has influenced conclusions regarding the enduring nature of certain concepts in the institutional structure of English town and country planning. The analysis has argued that the ongoing presence of contested concepts at the core of the ideology of the institution of 
national English planning, and which are also of importance to competing political ideologies, have helped secure its legitimation and longevity (even though their meanings and relations have changed over time).

Therefore, by focusing on how the meanings of and relations between essentially contested concepts of importance to planning have changed in mainstream political and policy discourse over time, it could be argued that this research emphasises continuity over discontuity and change. The analysis has sought to show that despite shifts in relations and meanings of certain concepts core to the institution of national English town and country planning, they have fundamentally endured and helped secure the legitimacy of the planning ideal. This potentially suppresses acknowledgement of the appearance and disappearance of various other concepts which may have shaped the institution of planning in different periods.

This kind of approach can be contrasted with, for example, the conception of history in Foucualdian archaeology, which more strongly emphasises discontinuities and sudden transformations: it seeks to crosssectionally analyse and compare discourses within particular time frames to understand how the unconscious, underlying 'archaeological' level of knowledge of particular periods was structured so as to allow a particular system of thought to achieve normative dominance, rather than tracing logical epistemological developments and continuities. In Foucault's archaeological history of the human sciences The Order of Things, for example, he talks of describing "an epistemological space specific to a particular period" rather than "the genesis of our sciences" ([1966] 2002: xi). Foucault's later genealogical method is based on his archaeological method, but is more focused on the analysis of the role of power relations in how 'discursive formations' constitute subjects, based on a conception of history which emphasises how systems of thought and conceptions of knowledge are built on contingent turns of history and the struggle for dominance of competing ideas and discourses.

A Foucauldian analysis of English planning history might therefore move beyond the purposive discourses through which the ideology of the formal institution of national English town and country planning may be traced, and in to a wider, fragmentary and more unconscious discursive social and cultural realm so as to understand how the 'discursive formation' (rather than the institution) of planning has been constituted at different times through a history "of the small and multiple changes that lead to alterations in trends of thinking and operating in any given epoch" (Downing, 2008: 15).

However, the analysis presented in this paper has been specifically concerned with mainstream political institutional discourse, largely constituted within the policy making sphere. Furthermore, Freeden's morphological approach as adapted here does not deny the dynamic quality of ideologies or the dynamism of the ideational morphology of institutions, and the resultant discontinuities. To be sure, there have been 
numerous other concepts which have played their part at various points in English planning's history. Some have been discussed here (e.g. 'region'). Their existence, and therefore the dynamism and discontinuity of the institution of planning, is not denied. However, by selecting concepts for analysis which have been judged to be of core ideological importance to planning, this paper necessarily focuses on their various permutations over time, rather than on the appearance (and disappearance) of other concepts which have not perhaps played as significant a role in the history of national English town and country planning.

It is also important to once again acknowledge the provisional nature of this kind of analysis - this paper is not arguing that the reading of the conceptual morphology of the institution of national English town and country planning presented here is the only reasonable interpretation. This reading is intended to be defensible and hopefully illuminating but not comprehensive; there are surely other readings which might focus on different aspects of the conceptual morphology of planning in order to illuminate different qualities.

\subsection{Conceptual Abstractions}

Freeden's analysis of political ideologies is focused on identifying and understanding the range of meanings given to concepts of importance to these ideologies, and how these meanings relate to one another. The approach taken in this paper has been to adjust this theory for the analysis of the relationship between political ideologies and the institution of national English town and country planning by identifying concepts which the institution has shared with competing ideologies, and tracing the range of contestation surrounding these concepts and how this has been related to institutional change.

The advantage of this approach is that it allows for a relatively systematic mapping of shifts in meaning and institutional structure over time. By selecting concepts as the unit of analysis, analytical attention becomes focused on how these concepts have shifted in meaning and relational position over time as traceable in the language of debates, policies and legislation in and around the institution of national English town and country planning. This is an approach which is relatively straightforward to operationalise across different time periods, thereby assisting with comparisons of ideologies and institutional structure at different snapshots in time (see Shepherd, 2017).

However, this strength is in other respects arguably a weakness. By focusing on abstract concepts such as liberty, property and the state, the analysis risks presenting such concepts as clearly bounded, universal and unitary despite the attempt to emphasise their essential contestability and, therefore, unstable nature. Žižek, for example, has critiqued the idea of an 'ideological Universal' such as 'freedom', arguing that it is 'false' because it "necessarily includes a specific case which breaks its unity, lays open its falsity" (Žižek [1989] 
2008: 16). For the concept of freedom (or liberty), this 'specific case' is that of the freedom of the worker to sell their own labour, which by so doing the worker in fact loses their freedom because "the real content of this free act of sale is the worker's enslavement to capital" (Žižek [1989] 2008: 17). Foucault offers a further critique by reminding us that a Nietzschean genealogical study of the concept of liberty suggests that it is "an 'invention of the ruling classes', and not fundamental to man's nature or at the root of his attachment to being and truth" because "class domination generates the idea of liberty" (Foucault, [1971] 1999: $371 \& 376)$.

However, it has been the focus of this paper not to critique and problematise these essentially contested concepts in themselves or trace their genealogy, but to explore their role in structuring the ideology of the institution of English town and country planning. Nevertheless, this does mean that by focusing on such concepts as they relate to political discourse in and around government, the analysis has been shaped by what the mainstream (rather than critical or more subversive) political theory and political philosophy literature can tell us about the breadth of potential meanings of these concepts, because it tends to be by the language of these literatures that mainstream political debate is often informed. In Althusserian terms, the analyst, and indeed politicians and policy makers, are always already interpellated by the political thinking enshrined in these literatures which precede the analysis and policy debate. It is essentially this kind of relationship to which Keynes is referring in the epigraph to this paper.

This form of analysis also means that there is a risk that the discussion of the variations of possible meanings of abstract political concepts and the ideologies they play a role in are de-contextualised from the specific periods of town and country planning being analysed. For example, discussions of the concept of liberty have inevitably been informed by abstract analyses in political theory and political philosophy literatures, not least liberal political philosophy. This can give the impression that the paper is arguing that it is a 'timeless' liberalism that has been of core importance to the ideology of the institution of English town and country planning. However, the argument is instead that it is the concept of liberty (rather than the ideology of liberalism) which has been of core importance. The concept of liberty (along with the other concepts discussed in this paper) is of significance to various political ideologies (e.g. historical permutations of liberalism, socialism and conservatism), but it has been contested in different ways and in relation to a different morphology of concepts in different periods. The paper has sought to analyse the relationship between these various permutations of concepts such as liberty (and their relationship with other concepts) in the ideology of the institution of English town and country planning over time. 
The risk of detachment from context has been addressed in this paper through attempts to relate the analysis of the various ideological concepts core to planning to the specific historical periods being discussed. However, another way to address this risk might be to employ a more specifically discourse focused form of analysis, as this would allow a more fine-grained account of the power of various discourses (rather than arrangements of abstract concepts) to constitute the practice of planning in different ways across different periods of time. It might also allow the scope of the analysis to extend beyond the confines of institutional government in to the broader and more diffuse realms of wider society and culture (see, for example, Raymond Williams's ([1976] 1988) discussion of 'key words'). However, this would be a fundamentally different project to the one reported in this paper, which has been specifically concerned with how the institution of national English town and country planning has been related to ideological debate in and around central government, as manifested in shifts in policies and laws.

\subsection{Ideology and Ideology Critique}

One of the reasons for selecting Freeden's morphological approach for the analysis of the relationship between political ideologies and changes in the institution of English town and country planning over time is that it seemingly comes with less overtly 'ideological baggage' than some other theories of ideology. Freeden's is not a 'critical theory' - it seeks to approach and understand ideologies 'on their own terms', rather than critique them from some privileged position of un-distorted insight. Given that the objective of the research has been to seek to understand the relationship between political ideologies and English planning (rather than critique it), it was important that the analysis did not itself begin from an overtly 'political' and therefore foreclosed position.

However this very quality also paradoxically means that, despite the apparently 'neutral' nature of Freeden's morphological theory of ideology, it clearly inevitably brings with it baggage of a different kind. This is apparent in its lack of a strong theory of power. Given the nature of ideology (particularly as discussed in section 2.1), this is a curious absence. By focusing on understanding abstract ideologies rather than critiquing them and how they may secure and reproduce domination, Freeden's approach could be criticised in Marxian terms as focusing on understanding the world rather than seeking to challenge and change it and, therefore, as being somewhat conservative.

However, it is important to first understand a phenomenon before one can critique it and seek to implement change. The research set out here may therefore be conceived as an initial step: it aims to assist in understanding the role of ideology in constructing approaches to planning with a view to opening out a field of inquiry. A next step may be to employ different (and more overtly critical) theories which are more able 
to handle an analysis of how ideology works to construct approaches to planning and what the political implications of this might be. Neo-Gramscian or Foucauldian approaches might be usefully employed here; a form of discursive institutionalism suitably adjusted to be able to account for power relations might also be helpful (see Carstensen \& Schmidt, 2016).

Such forms of analysis might critically examine the effects of shifts in meanings of key concepts on how problems are conceptualised and understood and how these in turn shape understandings of society, as exemplified in the following observation from Stuart Hall in relation to the New Labour project:

"I think the ideological dimension is very critical - the way the whole political discourse has been 'cleansed', so that public interest, public ownership, common goods, equality, the redistribution of wealth, the stubborn facts about poverty and inequality, etc, all become 'unspeakable'. That's an instance of the way ideology, through erasure, provided one of the conditions of existence of politics and the economy [...] The logic of 'spin' was to detach concepts from their previous associations and attach them to new meanings. You can see this process when they [New Labour] banished 'equality' from the vocabulary and started talking about fairness; when they banished 'capital' and started to talk about free markets; when they gave up on 'society' and started to use that weasel word 'community' instead. All these shifts of language were ways of deconstructing a form of consciousness which had governed political thinking on the left for a long time."

(Hall \& Massey, 2010: 61, 64)

\subsection{If Ideology is Everything, Maybe It's Nothing?}

The focus of this paper has been the relationship between political ideologies and institutional change. However, it is extremely important to emphasise that it is not the argument of this paper that the presence and activity of ideology is a necessary condition for institutional change. This could only be the case if one were to argue that for any action resulting in institutional change to occur, it has to be filtered through some kind of ideology which frames the institution and its place in the world and offers a range of potential actions through which it can be changed and that, therefore, ideology is present in every decision, every discursive interaction, every change.

This may be a defensible position at a very abstract theoretical level (see Althusser's concept of 'ideology in general' discussed in section 2.1), but it ceases to be of much analytical use when one engages with the murky complexities of political relations and actions. To paraphrase Wildavsky (1973) and Eagleton (2007: 7), if one conceives of ideology as everything, then maybe it's nothing? However, this paper has not argued 
that ideology is everything, or that it is a necessary condition for institutional change. It has instead sought to reveal the relationship between contested ideologically-loaded concepts, and institutional change by tracing their presence within the ideology of the institution of national English town and country planning over time.

This kind of analysis supports an argument that the forms of institutional change examined herein have been closely related to shifts in the ideological structures which have power over the institution. However, this has produced a necessarily partial picture, one which is focused on showing how ideologies manifest in the institution of English town and country planning and help contain and direct change, and simultaneously secure stability.

The research therefore offers an account of this relationship, but at the expense of a full analysis of institutional change per se. A full analysis of national English town and country planning institutional change and how it occurs would require a methodology and method which is capable of capturing historical and current social and economic context, power networks of key players, characteristics of these key players, institutional structure at various scales, electoral risk and strategy, the relationship between the institution and other institutions to which it relates, 'external shocks' such as the financial crisis, human error, unintended consequences, policy failure and disappointment, policies imposed from outside of the institution such as significant public sector cuts - to name a few. Some of these factors have been touched upon in this paper, but they have not been fully theorised and incorporated into the analysis. However, it is doubtful whether all of these factors could be fully and satisfactorily incorporated into any analysis, particularly a longitudinal one such as that contained in this paper (although, see Kingdon (2003) for an attempt at a synthesis of some of these). ${ }^{5}$

The contribution of this paper is not therefore towards a better understanding of how changes to the institution of national English town and country planning have occurred, but rather to an understanding of how and why ideology and ideologies have been factors in its change and stability.

\section{References}

Abercrombie, P., 1943. Town and country planning. 2nd edition. Oxford: Oxford University Press. Allmendinger, P., \& Thomas, H., 1998. Urban planning and the British new right. London: Routledge.

${ }^{5}$ For accounts of various epochs in the history of English planning, see Allmenginger, 2011; Allmendinger \& Thomas, 1998; Ashworth, 1954; Cherry, 1996; Cullingworth, 1975a, 1975b, 1979, 1981; Haar, 1951; Hague, 1984; Hall, 2002; Reade, 1987; Sutcliffe, 1980; Thornley, 1993; Ward, 2004. 
Allmendinger, P., 2011. New Labour and planning: from new right to new left. London \& New York: Routledge.

Allmendinger, P., and Haughton, G., 2015. Post-political regimes in English planning: from Third Way to Big Society. In: Metzger J, Allmendinger P and Osterlynck S (eds) Planning Against the Political: Democratic Deficits in European Territorial Governance. London: Routledge, pp.29-54.

Allmendinger, P., Haughton, G., \& Shepherd, E., 2016. Where is planning to be found? Material practices and the multiple spaces of planning. Environment and Planning C: Government and Policy, 34 (1): 38-51.

Althusser, L., [1971] 1984. Ideology and ideology state apparatuses (Notes towards an investigation). In: L. Althusser. Essays on ideology. Translated from the French by 'unknown'. London: Verso. pp. 160 .

Aron, R., [1957] 1968. The end of the ideological age? In: C. I. Waxman (ed). The end of ideology debate. New York: Simon \& Schuster. pp. 27- 48.

Ashworth, W., 1954. The genesis of modern British town planning. London: Routledge \& Kegan Paul.

Barker, R., 1978. Political ideas in modern Britain. London: Methuen \& Co.

Barlow, M., (chair). 1940. Report of the Royal Commission on the Distribution of the Industrial Population, Cmd 6153, Barlow Report. London: HMSO.

Barry, N., 2005. New right. In: K. Hickson (ed). The political thought of the Conservative Party since 1945. Basingstoke: Palgrave Macmillan. pp 28-50.

Barthes, R., 1972. Mythologies. Translated from the French by A. Lavers. London: Jonathan Cape.

Barthes, R., 1977. The Death of the Author. In: R. Barthes. Image-music-text. Translated from the French by S. Heath. London: Fontana Press. pp. 142-148.

Béland, D. \& Cox, R.H., (eds) 2011a. Ideas and politics in social science. Oxford: Oxford University Press.

Béland, D. \& Cox, R.H., 2011b. Introduction: ideas and politics. In: D. Béland, \& R.H.Cox (eds). Ideas and politics in social science. Oxford: Oxford University Press. pp. 3-20.

Bell, D., [1960] 2000. The end of ideology: On the exhaustion of political ideas in the fifties. Cambridge, Massachusetts and London, England: Harvard University Press.

Bell, D., 1988. The end of ideology revisited (Part I). Government and Opposition, 23 (2): 131 - 150.

Berlin, I., [1958] 2001. Two concepts of liberty. In: N. Warburton (ed). Freedom: an introduction with readings. London \& New York: Routledge. pp.127 - 136.

Beveridge, W., 1942. Social insurance and allied services, Cmd 6404, Beveridge Report. London: HMSO.

Blair, T., 1998. The third way: a new politics for a new century. London: The Fabian Society. 
Blond, P., 2008. Red Tory. In: J. Cruddas, \& J. Rutherford (eds). Is the future Conservative? London: Lawrence \& Wishart. pp. 79-90.

Blond, P., 2009. Rise of the red Tories. Prospect. 28 February 2009. [online] Available at: http://www.prospectmagazine.co.uk/features/riseoftheredtories [Accessed 6 January 2016].

Blyth, M., 2002. Institutions and ideas. In: D. Marsh, \& G. Stoker (eds). Theory and Methods in Political Science. Houndmills and New York: Palgrave McMillan. pp. 292-310.

Brown, T., 2016. Sustainability as empty signifier: Its rise, fall, and radical potential. Antipode, 48 (1): 115-133.

Buder, S., 1969. Ebenezer Howard: the genesis of the town planning movement. Journal of the American Institute of Planners, 35 (6): 390-398.

Butt, R., 1981. Economics are the method: the object is to change the soul: interview with Margaret Thatcher. Sunday Times. 1 May 1981. (online) Available at: http://www.margaretthatcher.org/document/104475 [Accessed on 5 June 2015].

Cameron, D., 2005. David Cameron's speech to the Conservative Party conference. The Guardian. 4 October 2005. (online) Available at: http://www.theguardian.com/politics/2005/oct/04/conservatives2005.conservatives3 [Accessed 26 November 2015].

Cameron, D., 2006. David Cameron's speech to the Conservative Party conference. The Guardian. 4 October 2006. (online) Available at: http://www.theguardian.com/politics/2006/oct/04/conservatives2006.conservatives [Accessed 26 November 2015].

Carstensen, M.B. \& Schmidt, V., 2016. Power through, over and in ideas: Conceptualizing ideational power in discursive institutionalism. Journal of European Public Policy, 23 (3): 318-337.

Carter, I. 2003. Liberty. In: R. Bellamy and A. Mason (eds), Political Concepts. Manchester and New York: Manchester University Press. pp. 4-15.

Cherry, G.E., 1996. Town planning in Britain since 1900. Oxford: Blackwell.

Civil Servant B, 2015. Personal interview with Civil Servant B. Interviewed by Edward Shepherd. [Telephone interview]. 9 October 2015.

Clark, G., 2010a. Community-led development, speech given to the Royal Town Planning Institute Annual Planning Convention, 29 June 2010. (online) Available at: http://www.gregclark.org/articles $\sim$ speeches/communityleddevelopmentaspeechtotheroyal/10 [Accessed 4 April 2016]. 
Clark, G., 2010b. Driving local growth, speech given at Local Government House, London, 28 October 2010. (online) Available at: https://www.gov.uk/government/speeches/driving-local-growth [Accessed 11 April 2016].

Cloud, D.L., \& Gunn, J., 2011. Introduction: W(h)ither ideology? Western Journal of Communication, 75 (4): 407-420.

Conservative Party, 1979. Conservative party manifesto. (online). Available at: http://www.politicsresources.net/area/uk/man/con79.htm [Accessed 9 April 2016].

Conservative Party, 2006. Built to last: the aims and values of the Conservative Party. London: The Conservative Party.

Conservative Party, 2009a. Control shift - returning power to local communities: policy green paper number 9. Brentford: TPF Group.

Conservative Party, 2009b. Strong foundations - building homes and communities: policy green paper number 10. Brentford: TPF Group.

Conservative Party, 2010. Open Source Planning: policy green paper number 14. Brentford: TPF Group.

Cox, A., 1984. Adversary politics and land: the conflict over land and property policy in post-war Britain. Cambridge: Cambridge University Press.

Crosland, A., [1956] 2006. The future of socialism. London: Constable.

Cullingworth, J.B., 1975a. Environmental planning 1939 - 1969 volume 1: Reconstruction and land use planning 1939 - 1947. London: HMSO.

Cullingworth, J.B., 1975b. Environmental planning 1939 - 1969 volume 2: National parks and recreation in the countryside. London: HMSO.

Cullingworth, J.B., 1979. Environmental planning 1939 - 1969 volume 3: New towns policy. London: HMSO.

Cullingworth, J.B., 1981. Environmental planning 1939 - 1969 volume 4: Land values, compensation and betterment. London: HMSO.

Cullingworth, J.B., 1988. Town and country planning in Britain. 10th edition. London: Unwin Hyman.

DCLG (Department for Communities and Local Government), 2011. Relaxation of planning rules for change of use from commercial to residential: consultation. London: DCLG Publications. (online) Available at: https://www.gov.uk/government/uploads/system/uploads/attachment_data/file/8491/1883189.pdf [Accessed 14 April 2016].

DCLG (Department for Communities and Local Government), 2012a. Common sense planning reform to create more homes and boost the high street. Press release, 1 September 2012. (online) Available at http://www.communities.gov.uk/news/corporate/2208810 [Accessed 7 October 2012] 
DCLG (Department for Communities and Local Government), 2012b. National planning policy framework. London: HMSO. (online) Available at: https://www.gov.uk/government/uploads/system/uploads/attachment_data/file/6077/2116950.pdf [Accessed 14 April 2016].

Ditt, K., \& Rafferty, J., 1996. Nature conservation in England and Germany 1900-70: forerunner of environmental protection? Contemporary European History, 5 (1): 1-28.

Dommett, K., 2012. Conceptualising party political ideology: an exploration of party modernisation in Britain. PhD Thesis. University of Sheffield. UK. (online) Available at: http://etheses.whiterose.ac.uk/2812/ [Accessed 14 April 2016].

Dorey, P., 2011. British conservatism: the politics and philosophy of inequality. London and New York: Palgrave Macmillan.

Downing, L., 2008. The Cambridge introduction to Michel Foucault. Cambridge: Cambridge University Press.

DTLR (Department of Transport, Local Government and the Regions), 2001. Planning: delivering a fundamental change. London: HMSO. (online) Available at: http://webarchive.nationalarchives.gov.uk/20120919132719/www.communities.gov.uk/archived/pu blications/planningandbuilding/planningdelivering [Accessed 10 April 2016].

DTLR (Department of Transport, Local Government and the Regions), 2002. Sustainable communities: delivering through planning. London: HMSO.

Dutton, D., 1997. British politics since 1945. 2nd edition. Oxford: Blackwell.

Eagleton, T., 2007. Ideology: an introduction. New and updated edition. London: Verso.

Eccleshall, R., 1986. British liberalism: liberal thought from 1640s to 1980s. London \& New York: Longman.

Editorial, 1941. Prelude to planning. The Economist. 26 July 1941, pp. 97-98; Issue 5109. (online) Available at: https://global.factiva.com [Accessed 8 January 2015].

Engels, F., \& Marx, K., [1846] 1970. The German ideology student edition. Translated from the German by 'unknown'. London: Lawrence \& Wishart.

Evans, S., 2010. 'Mother's boy': David Cameron and Margaret Thatcher. The British Journal of Politics and International Relations, 12 (3): 325-343.

Foley, D.L., 1960. British Town Planning: One Ideology or Three? The British Journal of Sociology, 11 (3): 211-231.

Foley, D.L., 1962. Idea and influence: the Town and Country Planning Association. Journal of the American Institute of Planners, 28 (1): 10-17. 
Foucault, M., [1966] 2002. The order of things: An archeaology of the human sciences. Translated from the French by 'unknown'. London and New York: Routledge.

Foucault, M., [1971] 1999 . Nietzsche, genealogy, history. In: J.D. Faubion (ed). Aesthetics, method and epistemology (Essential works of Michel Foucault, 1954 - 1984 Vol 2). Translated from the French by D.F. Brouchard and S. Simon. New York: The New Press. pp. 369 - 391.

Foucault, M., [1975] 1977 . Discipline and punish: The birth of the prison. Translated from the French by A. Sheridan. London: Allen Lane.

Foucault, M., [1977] 1980a. Two lectures. Translated from the Italian by K. Soper. In: C. Gordon (ed). Power/knowledge: Selected interviews and other writings. pp. 109-133. pp. 78-108.

Foucault, M., [1977] 1980b. Truth and power. Translated from the Italian by C. Gordon. In: C. Gordon (ed). Power/knowledge: Selected interviews and other writings. pp. 109-133.

Freeden, M., 1990. The stranger at the feast: Ideology and public policy in twentieth century Britain. Twentieth Century British History, 1 (1): 9 - 34.

Freeden, M., 1996. Ideologies and political theory: a conceptual approach. Oxford: Oxford University Press.

Freeden, M., 1998. Ideologies and political theory: a conceptual approach. [ebook] Oxford: Oxford University Press. Available at: http://www.oxfordscholarship.com/view/10.1093/019829414X.001.0001/acprof-9780198294146 [Accessed 18 July 2013].

Freeden, M., 2001. Editorial: What is special about ideologies? Journal of Political Ideologies, 6 (1): 512.

Freeden, M., 2003. Ideology: a very short introduction. Oxford: Oxford University Press.

Freeden, M., 2006. Ideology and political theory. Journal of Political Ideologies, 11 (1): 3-22.

Freeden, M., 2013a. The morphological analysis of ideology. In: Freeden M, Sargeant LT and Stears MS (eds) The Oxford Handbook of Political Ideologies. Oxford: Oxford University Press, pp.115-134.

Freeden, M., 2013b. The political theory of political thinking: The anatomy of a practice. Oxford: Oxford University Press.

Gallie, W.B., 1956. Essentially contested concepts. Proceedings of the Aristotelian Society, New Series. 56 (1955-56): 167-198.

Gamble, A., 1984. Conclusion: Part B. In: A. M. Gamble and S. A. Walkland. The British Party System and Economic Policy 1945 - 1983. Oxford: Clarandon Press. pp.170 - 187.

Gatley, J., \& Clark, G., 2015. News Story: Liverpool devolution deal boosts the Northern Powerhouse. 17 November 2015. (online) Available at: https://www.gov.uk/government/news/liverpool-devolutiondeal-boosts-the-northern-powerhouse [Accessed 8 January 2016]. 
Geddes, P., 1915. Cities in evolution: an introduction to the town planning movement and to the study of civics. London: Williams and Norgate. [ebook] Available at: https://archive.org/details/citiesinevolutio00gedduoft [Accessed 9 April 2016].

George, H., [1881] 2011. Progress and poverty. Cambridge: Cambridge University Press. [ebook] Available at: doi: 10.1017/CBO9780511693687 [Accessed 6 February 2016].

Gilmour, I. 1977. Inside right: a study of conservatism. London: Hutchinson \& Co Ltd.

Glass, R., 1959. The evaluation of planning: some sociological considerations. International social science journal, 11 (3): 393 - 409.

Gramsci, A., 1971. Selections from the prison notebooks of Antonio Gramsci. Translated from the Italian by Q. Hoare \& G. Nowell Smith (eds). London: Lawrence \& Wishart.

Gray, J., 1997. The undoing of Conservatism. In: J. Gray \& D. Willetts. Is Conservatism dead? London: The Social Market Foundation and Profile Books Ltd. pp. 1 - 65.

Green, T.H., [1888] 2011. Lecture on liberal legislation and freedom of contract. In: R.L. Nettleship (ed), Works of Thomas Hill Green Volume 3. Cambridge: Cambridge University Press. pp. 365-386.

Haar, C.M., 1951. Land planning law in a free society. Harvard: Harvard University Press.

Hague, C., 1984. The development of planning thought: a critical perspective. London: Hutchinson.

Hall, P., 2002. Cities of tomorrow: an intellectual history of urban planning and design in the twentieth century. 3rd edition. Oxford: Blackwell.

Hall, P.A., \& Thelen, K., 2008. Institutional change in varieties of capitalism. Socio-Economic Review. 7 (1): 7-34.

Hall, S., \& Massey, D., 2010. Interpreting the crisis. Soundings, Issue 44 (Spring): 57 - 71.

Hall, S., 1990. The emergence of cultural studies and the crisis of the humanities. The Humanities as Social Technology, 53 (October): 11-23.

Hardy, D., 1991. From garden cities to new towns: campaigning for town and country planning, 1899 1946. London, New York, Tokyo, Melbourne, Madras: E \& FN Spon.

Harvey, D., 1989. The condition of postmodernity: An enquiry in to the origins of cultural change. Oxford: Blackwell.

Harvey, D., 2005. A brief history of neoliberalism. Oxford: Oxford University Press.

Hay, C., 2001. The invocation of external economic constraint: A geneology of the concept of globalization in the political economy of the British Labour Party, 1973 - 2000. The European Legacy. 6 (2): 233 - 249.

Hay, C., 2002. Political analysis: a critical introduction. Houndmills \& New York: Palgrave. Hayek, F.A., [1944] 2006. The road to serfdom. London and New York: Routledge. 
HC Deb 11 May 1943 vol 389 cc 500-585 (online) Available at:

http://hansard.millbanksystems.com/commons/1943/may/11/town-and-country-planninginterim\#S5CV0389P0_19430511_HOC_224 [Accessed 9 January 2015].

HC Deb 17 December 2002 vol 396 cc 729-816 (online) Available at: http://www.publications.parliament.uk/pa/cm200203/cmhansrd/vo021217/debtext/2121715.htm\#21217-15_head2 [Accessed 10 April 2016].

HC Deb 17 January 2011 vol 521 cc 557-660 (online) Available at: http://www.publications.parliament.uk/pa/cm201011/cmhansrd/cm110117/debtext/1101170001.htm\#1101176000001 [Accessed 11 April 2016].

HC Deb 21 March 1945 vol 409 cc 821-949 (online) Available at: http://hansard.millbanksystems.com/commons/1945/mar/21/distribution-of-industrybill\#column_821 [Accessed 8 January 2015].

HC Deb 29 January 1947 vol 432 cc 947-1075 (online) Available at: http://hansard.millbanksystems.com/commons/1947/jan/29/town-and-country-planning-bill [Accessed 13 January 2015].

HC Deb 30 January 1947 vol 432 cc 1129-1241 (online) Available at: http://hansard.millbanksystems.com/commons/1947/jan/30/town-and-country-planning-bill [Accessed 13 January 2015].

Heffernan, R., 2000. New Labour and Thatcherism: political change in Britain. Basingstoke \& London: Macmillan.

Heywood, A., 2012. Political ideologies: an introduction. 5th edition. Houndmills, Basingstoke: Palgrave Macmillan.

Heywood, A., 2015. Political theory: an introduction. 4th edition. London \& New York: Palgrave Macmillan.

Hickson, K., 2004. The postwar consensus revisited. The Political Quarterly, 75 (2): 142 - 154.

HL Deb 05 June 1947 vol 148 cc 199-278 (online) Available at: https://api.parliament.uk/historichansard/lords/1947/jun/05/town-and-country-planning-bill [Accessed 23 August 2018].

HL Deb 04 June 1947 vol 148 cc 123-96 (online) Available at: https://api.parliament.uk/historichansard/lords/1947/jun/04/town-and-country-planning-bill [Accessed 23 August 2018].

HM Government, 2010. Decentralisation and Localism Bill: an essential guide. London: DCLG. (online) Available at: https://www.gov.uk/government/uploads/system/uploads/attachment_data/file/5951/1793908.pdf [Accessed 14 April 2016]. 
Hobhouse, L.T., [1911] 1994a. Liberalism. In: J. Meadowcroft (ed). Liberalism and Other Writings. Cambridge: Cambridge University Press. pp.1-120.

Hobhouse, L.T., [1913] 1994b. The historical evolution of property in fact and in idea. In: J. Meadowcroft (ed). Liberalism and Other Writings. Cambridge: Cambridge University Press. pp. 175-198.

Hobhouse, L.T., 1905. Democracy and reaction. Putnam.

Hobson, J.A., 1897. The influence of Henry George in England. Fortnightly Review, 1897 (62): 835 844.

Holborow, M., 2007. Language, ideology and neoliberalism. Journal of Language and Politics, 6 (1): 5173.

House of Commons, Communities and Local Government Committee, 2011a. Abolition of regional spatial strategies: a planning vacuum (HC 517, Second report of session 2010-11) - Volume I: Report, together with formal minutes, oral and written evidence. London: TSO (The Stationary Office Limited).

House of Commons, Communities and Local Government Committee, 2011a. Abolition of regional spatial strategies: a planning vacuum (HC 517, Second report of session 2010-11) - Volume I: Report, together with formal minutes, oral and written evidence. London: TSO (The Stationary Office Limited).

House of Commons, Communities and Local Government Committee, 2011b. The national planning policy framework (HC 1526, Eighth report of session 2010-12) - Volume I: Report, together with formal minutes, oral and written evidence. London: TSO (The Stationary Office Limited).

Howard, E., [1898] 1902. Garden cities of tomorrow. London: Swann Sonnenschein \& Co. (online) Available at: https://archive.org/details/gardencitiesofto00howa [Accessed 9 April 2016].

Jessop, B., 2015. Margaret Thatcher and Thatcherism: Dead but not buried. British Politics, 10 (1): 16 30.

Johnston, B., 2016. Planning in 2016: Policy and legislation preview. Planning Resource. 8 January 2016. (online) Available at: http://www.planningresource.co.uk/article/1378590/planning-2016-policylegislation-preview [Accessed 8 January 2016].

Keynes, J.M., 1938. The general theory of employment, interest and money. London: Macmillan Press. Kingdon, J.W., 2003. Agendas, alternatives and public policies. 2nd edition. New York: Longman.

Kirkup, J., 2011. National Trust's 'nihilistic selfishness' on planning. The Telegraph. 23 August 2011. (online). Available at: http://www.telegraph.co.uk/news/politics/8718231/National-Trustsnihilistic-selfishness-on-planning.html [Accessed 2 January 2016].

Labour Party, 1945. Labour Party Manifesto. (online) Available at: http://www.politicsresources.net/area/uk/man/lab45.htm [Accessed 4 May 2015]. 
Labour Party, 1983. The new hope for Britain: Labour Party Manifesto. (online) Available at: http://www.politicsresources.net/area/uk/man/lab83.htm [Accessed 4 May 2015].

Labour Party, 2014. Labour Party rule book 2014. (online) Available at: https://rotherhampolitics.files.wordpress.com/2014/08/rule-book-2014-collins-review.pdf [Accessed 31 March 2016].

Laclau, E., \& Mouffe, C., [1985] 2001. Hegemony and socialist strategy: Towards a radical democratic politics. 2nd edition. London \& New York: Verso.

Larrain, J., 1979. The concept of ideology. London: Hutchinson \& Co.

Leach, R., 2009. Political ideology in Britain. Houndmills, Basingstoke: Palgrave Macmillan.

Leach, R., Coxhall, B., \& Robins, L., 2011. British politics. 2nd edition. Houndmills, Basingstoke: Palgrave Macmillan.

Lees, E., \& Shepherd, E., 2015. Incoherence and incompatibility in planning law. International Journal of Law in the Built Environment, 7 (2): 111 - 126.

Lenin, V.I., [1902] 1962. What is to be done? The Marx/Engels Internet Archive. Translated from the German by J. Fineberg \& G. Hanna. (online) Available at: https://www.marxists.org/archive/lenin/works/1901/witbd/index.htm [Accessed 20 April 2016].

Letwin, O., \& Finlayson, A., 2008. Oliver Letwin MP interviewed by Alan Finlayson: from economic revolution to social revolution. In: J. Cruddas \& J. Rutherford (eds). Is the future Conservative? London: Lawrence \& Wishart. pp. 71-78.

Letwin, O., 2002. Sustainability and society, speech given to the Adam Smith Institute, 3 July 2002. (online) Available at: http://www.webarchive.org.uk/wayback/archive/20080908030046/http://www.conservatives.com/ti le.do?def=news.story.page\&obj_id=33854\&speeches=1 [Accessed 11 April 2016].

Letwin, O., 2003a. The Conservative Party has to be the party of the inner cities, speech at the Roxy Cinema, Brixton, London, 23 June 2003. (online) Available at: http://www.webarchive.org.uk/wayback/archive/20080908025957/http://www.conservatives.com/ti le.do?def=news.story.page\&obj_id=64998\&speeches=1 [Accessed 11 April 2016].

Letwin, O., 2003b. The neighbourly society: collected speeches 2001 - 2003. London: Centre for Policy Studies. (online) Available at: https://www.cps.org.uk/files/reports/original/111028111955TheNeighbourlySociety.pdf [Accessed 8 April 2016].

Letwin, O., 2005. Healthy cities, healthy countryside. In: J. Tate (ed). What's right now: Conservative essays on the role of civil society, markets and the state. London: The Social Market Foundation.

LGA (Local Government Association), 2009. LGA On The Day Briefing - Conservative Party Housing Green Paper. 7 April 2009. (online) Available at: 
http://www.local.gov.uk/c/document_library/get_file?uuid=a083828d-7a97-4856-81f893d2e75a9567\&groupId=10180 [Accessed 14 April 2016].

Lobbyist A., 2015. Personal interview with Lobbyist A. Interviewed by Edward Shepherd. [Telephone interview]. 20 August 2015.

Lobbyist B., 2013. Personal interview with Lobbyist B. Interviewed by Edward Shepherd. [Telephone interview]. 7 October 2013.

Lobbyist G., 2015. Personal interview with Lobbyist G. Interviewed by Edward Shepherd. [Telephone interview]. 15 December 2015.

Lobbyist L., 2015. Personal interview with Lobbyist L. Interviewed by Edward Shepherd. [Telephone interview]. 12 March 2015.

Locke, J., [1690] 2001. Second treatise of government. Raleigh, NC : Alex Catalogue. (online) Available at: https://ebookcentral.proquest.com/lib/reading/detail.action?docID=3314655 [Accessed 3 December 2017].

MacCallum, G.C., 1967. Negative and positive freedom. The Philosophical Review, 76 (3): 312-334.

MacKenzie, I., 1994. Introduction: the arena of ideology. In: R. Eccleshall, V. Geoghegan, R. Jay, M. Kenny, I. MacKenzie, \& R. Wilford. Political ideologies: an introduction. 2nd edition. London and New York: Routledge. pp. 1-27.

Mannheim, K., [1929] 1954. Preliminary approach to the problem. In: K. Mannheim. Ideology and utopia: An introduction to the sociology of knowledge. Translated from the German by L. Wirth \& E. Shils. New York: Harcourt, Brace \& Co Ltd; London: Routledge \& Kegan Paul Ltd. pp. 1-48.

Mannheim, K., [1936] 1954. Ideology and utopia. In: K. Mannheim. Ideology and utopia: An introduction to the sociology of knowledge. Translated from the German by L. Wirth \& E. Shils. New York: Harcourt, Brace \& Co Ltd; London: Routledge \& Kegan Paul Ltd. pp. 49-96.

Marx, K., Engels, F. [1848] 1969. Manifesto of the Communist Party. Marx/Engels internet archive. Translated from the German by S. Moore. (online) Available at: https://www.marxists.org/archive/marx/works/download/pdf/Manifesto.pdf [Accessed 11 April 2016].

McAuslan, P., 1980. The ideologies of planning law. Urban and regional planning series; vol. 22. Oxford: Pergamon Press.

McKay, D.H., and Cox, A.W., 1979. The politics of urban change. London: Croom Helm.

MTCP \& SSS (Minister of Town and Country Planning \& Secretary of State for Scotland), 1944. The control of land use, Cmd 6537, white paper, London: HMSO.

Nair, G., \& Poyner, D., 2006. The flight from the land? Rural migration in south-east Shropshire in the late nineteenth century. Rural History, 17 (02): 167 - 186. 
Nuffield Foundation, 1986. Town and Country Planning, Nuffield Report. London: Nuffield Foundation.

Oakeshott, M. [1947] 1991. Rationalism in politics. In: T. Fuller (ed). Rationalism in politics and other essays new and expanded edition. Indianapolis: The Liberty Fund. pp. 6-42.

Osborne, G., \& Pickles, E., 2011. Planning reforms boost local power and growth, 4 September 2011. (online) Available at: https://www.gov.uk/government/speeches/planning-reforms-boost-localpower-and-growth [Accessed 1 April 2016].

Osborne, G., 2006. Championing affordable and sustainable home ownership, speech given to Property Week Conference, 8 February 2006. (online) Available at: http://www.webarchive.org.uk/wayback/archive/20080908030331/https://www.conservatives.com/ tile.do?def=news.story.page\&obj_id=127785\&speeches=1 [Accessed 11 April 2016].

Osborne, G., 2015. Chancellor on building a Northern Powerhouse, speech at Victoria Warehouse, Manchester, 14 May 2015 (online) Available at: https://www.gov.uk/government/speeches/chancellor-on-building-a-northern-powerhouse [Accessed 8 January 2016].

Pelling, H., \& Reid, A.J., 1996. A short history of the Labour Party. 11th edition. Houndmills, Basingstoke: Macmillan.

Pickles, E., 2010. Revoking regional strategies, written statement to Parliament, 6 July 2010. (online) Available at: https://www.gov.uk/government/speeches/revoking-regional-strategies [Accessed 11 April 2016].

Pickles, E., 2016. Personal interview with Sir Eric Pickles MP. Interviewed by Edward Shepherd. [Faceto-face interview]. London, 19 January 2016.

Pimlott, B., Kavanagh, D., \& Morris, P., 1989. Is post war consensus a myth? Contemporary Record, 2 (6): $12-15$.

Policy Influencer A., 2015. Personal interview with Policy Influencer A. Interviewed by Edward Shepherd. [Telephone interview]. 10 April 2015.

Politician A., 2015. Personal interview with Politician A. Interviewed by Edward Shepherd. [Face-to-face interview]. London, 18 March 2015.

Politician B., 2015. Personal interview with Politician B. Interviewed by Edward Shepherd. [Telephone interview]. 6 October 2015.

Practitioner A, 2015. Personal interview with Practitioner A. Interviewed by Edward Shepherd. [Telephone interview]. 8 October 2015.

Purvis, T., \& Hunt, A., 1993. Discourse, ideology, discourse, ideology, discourse, ideology....The British Journal of Sociology, 44 (3): 473-499. 
Quartermain, S., 2010. DCLG Chief planning officer letter: revocation of regional strategies, 6 July 2010. (online) Available at:

https://www.gov.uk/government/uploads/system/uploads/attachment_data/file/7995/100706-

Letter_to_Chief_Planning_Officers-_Revocation_of_Regional_Strategies.pdf [Accessed 11 April 2016].

Reade, E., 1987. British town and country planning. Milton Keynes: Open University Press.

Reith, J.C.W., (chair) 1946. Final report of the New Towns Committee, Cmd 6876, Reith Report, London: HMSO.

Rittel, H.W.J., \& Webber, M.M., 1973. Dilemmas in a general theory of planning. Policy Sciences, 4 (4): 155-169.

RTPI (Royal Town Planning Institute), 2010. Localism must not miss the bigger picture on planning, 5 August 2010. (online) Available at: http://www.rtpi.org.uk/briefing-room/newsreleases/2010/august/localism-must-not-miss-the-bigger-picture-on-planning/ [Accessed 8 April 2016].

Ryan, A., 2012. On politics: a history of political thought from Herodotus to the present. London: Penguin Group.

Saussure, F. de., 1983. Course in general linguistics. C. Bally \& A. Sechehaye with A. Riedlinger. Translated from the French by R. Harris. London: Duckworth.

Schmidt, V.A., 2008. Discursive institutionalism: The explanatory power of ideas and discourse. Annual Review of Political Science, 11 (1): 303-326.

Schmidt, V.A., 2010. Taking ideas and discourse seriously: explaining change through discursive institutionalism as the fourth 'new institutionalism'. European Political Science Review, 2 (1): 125.

Schmidt, V.A., 2014. Speaking to the markets or to the people? A discursive institutionalist analysis of the EU's sovereign debt crisis. The British Journal of Politics and International Relations, 16 (1): 188-209.

Scott, L.F., (chair). 1942. Report of the Committee on Land Utilisation in Rural Areas, Cm 6378, Scott Report. London: HMSO.

Sharp, T., 1945. Town planning. Further revised edition. Harmondsworth: Penguin Books.

Shepherd, E., 2016. Liberty, property and the state: the ideology of the institution of national English town and country planning. PhD Thesis, University of Cambridge, UK.

Shepherd, E., 2017. Continuity and change in the institution of town and country planning: Modelling the role of ideology. Planning Theory. 1-20. 
Skidelsky, R., 1996. The fall of Keynsianism. In: D. Marquand \& A. Seldon (eds). The ideas that shaped post-war Britain. London: Fontana Press. pp. 41-66.

Sparrow, A., 2011. Rural pressure groups reject minister's 'leftwing smear campaign' claim. The Guardian. 7 August 2011. (online) Available at: http://www.theguardian.com/uk/2011/aug/07/ruralpressure-groups-deny-leftwing-smear [Accessed 3 January 2016].

Stevenson, J., 2005. The countryside, planning, and civil society in Britain, 1926-1947. In: J. Harris (ed). Civil society in British history: ideas, identities, institutions. Oxford: Oxford University Press. pp. 191-211.

Straw, J., 1999. Rights and responsibilities in the New Democracy, speech given to The Constitution Unit, University College London, 27 October 1999. (online) Available at: https://www.ucl.ac.uk/spp/publications/unit-publications/53.pdf [Accessed 14 April 2016].

Sutcliffe, A. (ed). 1980. The rise of modern urban planning 1800 - 1914. London: Mansell.

Taylor, N., 2009. Tensions and contradictions Left and Right: The predictable disappointments of planning under New Labour in historical perspective. Planning Practice and Research, 24 (1): 57 70.

Thatcher, M., 1993. The Downing Street years. London: Harper Collins.

Thompson, N., 2004. The centre. In: R. Plant, D. Kavanagh, \& P. Morris (eds). The struggle for Labour's soul: Understanding Labour's political thought since 1945. London and New York: Routledge. pp. 47-67.

Thornley, A., 1991. Urban planning under Thatcherism: the challenge of the market. London: Routledge.

Thornley, A., 1993. Urban planning under Thatcherism: the challenge of the market. 2nd edition. London: Routledge.

Tichelar, M., 2003. The conflict over property rights during the Second World War: the Labour Party's abandonment of land nationalization. Twentieth Century British History, 14 (2): 165-188.

Town and Country Planning Act 1932 (22 \& 23 Geo 5., Ch. 48). London: HMSO. (online) Available at: http://legalresearch.westlaw.co.uk/ [Accessed 9 January 2015].

Uthwatt, A.A., (chair). 1942. Final report of the Expert Committee on Compensation and Betterment, Cmd 6386, Uthwatt Report, London: HMSO.

Ward, S.V., 2004. Planning and urban change. 2nd Edition. London: Sage.

Wildavsky, A., 1973. If planning is everything, maybe it's nothing. Policy Sciences, 4 (2): 127-153.

Willetts, D., 1992. Modern conservatism. London: Penguin Books.

Willetts, D., 1997a. Civic Conservatism, In: J. Gray \& D. Willetts. Is Conservatism dead? London: The Social Market Foundation and Profile Books Ltd. pp. 67 - 141. 
Willetts, D., 1997b. Conclusion, In: J. Gray \& D. Willetts. Is Conservatism dead? London: The Social Market Foundation and Profile Books Ltd. pp. 142 - 180.

Willetts, D., 2002a. Conservatives focus attention on poverty, speech given to Conservative Future, 27 February 2002. (online) Available at: http://www.webarchive.org.uk/wayback/archive/20080908025830/http://www.conservatives.com/ti le.do?def=news.story.page\&obj_id=25817\&speeches=1 [Accessed 11 April 2016].

Willetts, D., 2002b. Making sense of society, speech given to Policy Exchange, London 17 September 2002. (online) Available at: http://www.webarchive.org.uk/wayback/archive/20080908030033/http://www.conservatives.com/ti le.do?def=news.story.page\&obj_id=39235\&speeches=1 [Accessed 11 April 2016].

Willetts, D., 2003. Conservatism and Christian democracy, speech, 10 December 2003. (online) Available at:

http://www.webarchive.org.uk/wayback/archive/20080908031144/https://www.conservatives.com/ tile.do?def=news.story.page\&obj_id=81937\&speeches=1 [Accessed 11 April 2016].

Willetts, D., 2005a. Compassionate Conservatism and the war on poverty, speech given to Centre for Social Justice at the Harrow Club, London 6 January 2005. (online) Available at: http://www.webarchive.org.uk/wayback/archive/20080908025202/https://www.conservatives.com/ tile.do?def=news.story.page\&obj_id=118477\&speeches=1 [Accessed 11 April 2016].

Willetts, D., 2005b. A new Conservatism for a new Century, speech given to Social Market Foundation, London 2 June 2005. (online) Available at: http://www.webarchive.org.uk/wayback/archive/20080908025413/https://www.conservatives.com/ tile.do?def=news.story.page\&obj_id=123209\&speeches=1 [Accessed 11 April 2016].

Williams, R., [1976] 1988. Keywords: A vocabulary of culture and society. London: Fontana Press.

Williams, R., 1960. Culture and society 1780 - 1950. New York: Anchor Books.

Williams, R., 1977. Marxism and literature. Oxford: Oxford University Press.

Williams-Ellis, C., 1928. England and the octopus. London: Geoffrey Bles.

Zhao, Y., 1993. The 'end of ideology' again? The concept of ideology in the era of post-modern theory. The Canadian Journal of Sociology / Cahiers canadiens de sociologie, 18 (1): 70-85.

Žižek, S., [1989] 2008. The sublime object of ideology. London: Verso. 